US Army Corps

of Engineers

Waterways Experiment

Station

Monitoring Completed Navigation Projects Program

\title{
Monitoring of Harbor Improvements
}

at St. Paul Harbor, St. Paul Island, Alaska

by Robert R. Bottin, Jr., WES

Kenneth J. Eisses, Alaska District

Approved For Public Release; Distribution Is Unlimited

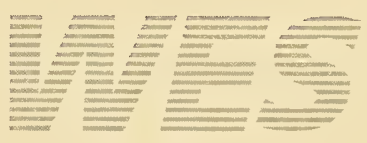

TA

7

W34

2. $\mathrm{CHL}$ $17-13$

Prepared for Headquarters, U.S. Army Corps of Engineers 
The contents of this report are not to be used for advertising, publication, or promotional purposes. Citation of trade names does not constitute an official endorsement or approval of the use of such commercial products.

The findings of this report are not to be construed as an official Department of the Army position, unless so designated by other authorized documents. 


\section{Monitoring of Harbor Improvements at St. Paul Harbor, St. Paul Island, Alaska}

by Robert R. Bottin, Jr.

U.S. Army Corps of Engineers

Waterways Experiment Station

3909 Halls Ferry Road

Vicksburg, MS 39180-6199

Kenneth J. Eisses

U.S. Army Engineer District, Alaska

Anchorage, AK 99506-0898

Final report

Approved for public release; distribution is unlimited

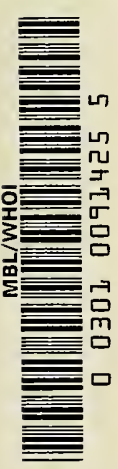




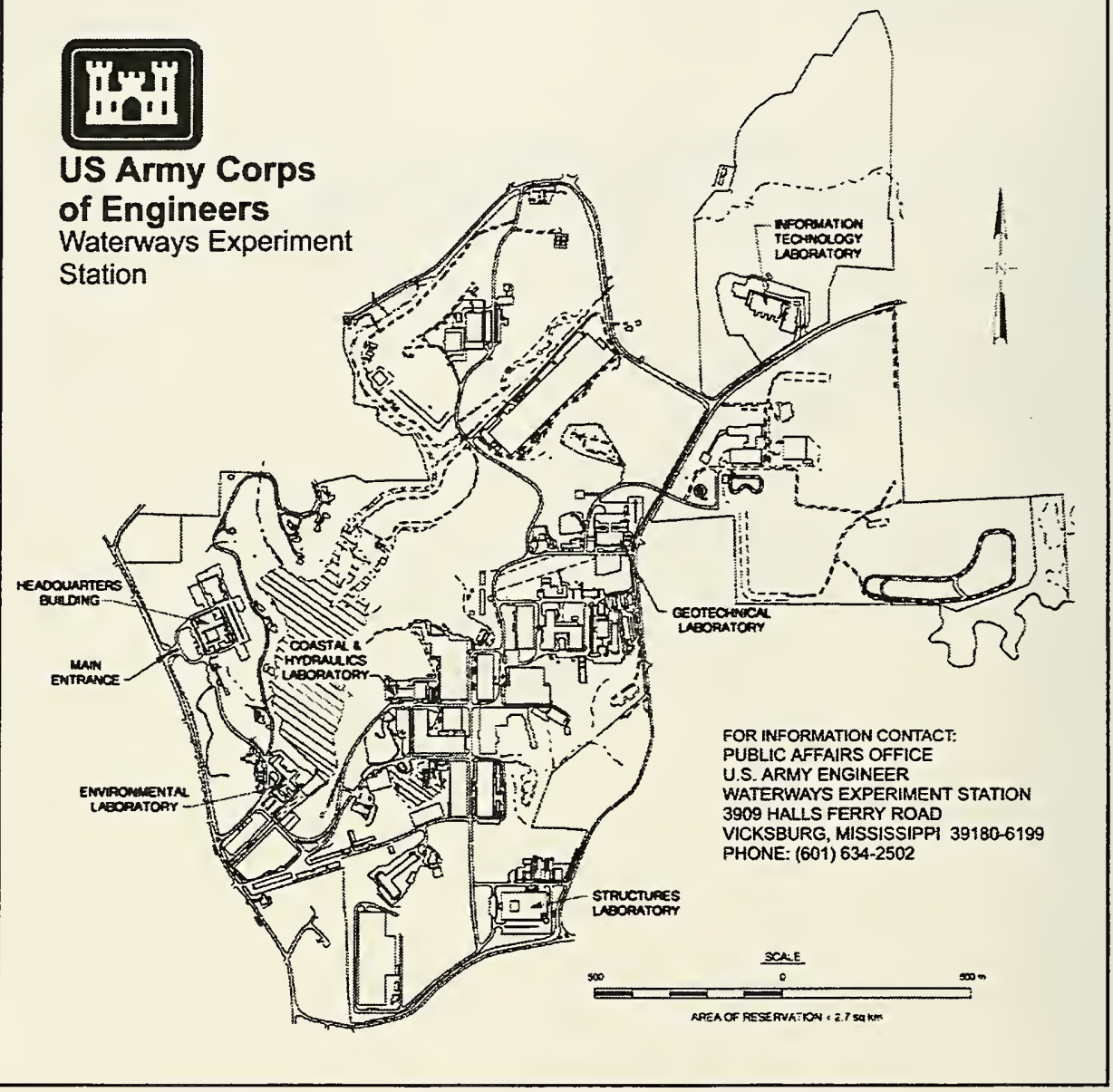

Waterways Experiment Station Cataloging-in-Publication Data

Bottin, Robert R.

Monitoring of harbor improvements at St. Paul Harbor, St. Paul Island, Alaska / by Robert

R. Bottin, Jr., Kenneth J. Eisses ; prepared for U.S. Army Corps of Engineers.

123 p. : ill. ; $28 \mathrm{~cm}$. -- (Technical report ; CHL-97-13).

Includes bibliographic references.

1. Harbors - Alaska - Saint Paul Island. 2. Saint Paul Island (Alaska) I. Eisses, Kenneth J. II. United States. Army. Corps of Engineers. III. U.S. Army Engineer Waterways Experiment Station. IV. Coastal and Hydraulics Laboratory (U.S. Army Engineer Waterways Experiment Station) V. Monitoring Completed Navigation Projects Program (U.S.) VI. Title. VII. Series: Technical report (U.S. Army Engineer Waterways Experiment Station) ; CHL97-13.

TA7 W34 no.CHL-97-13 


\section{Contents}

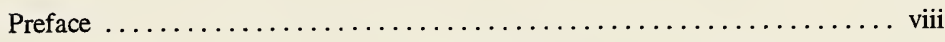

Conversion Factors Non-SI to SI (Metric) Units of Measurement . . . . . . . X

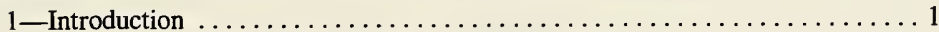

Monitoring Completed Navigation Projects Program $\ldots \ldots \ldots \ldots \ldots \ldots \ldots 1$

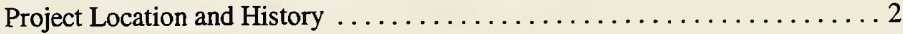

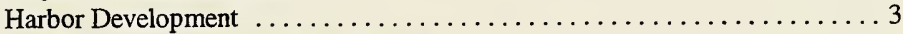

Hydraulic Model Studies of the Harbor $\ldots \ldots \ldots \ldots \ldots \ldots \ldots \ldots \ldots \ldots \ldots \ldots \ldots \ldots$

$2-$ Monitoring Program $\ldots \ldots \ldots \ldots \ldots \ldots \ldots \ldots \ldots \ldots \ldots \ldots \ldots \ldots \ldots \ldots \ldots \ldots \ldots \ldots \ldots$

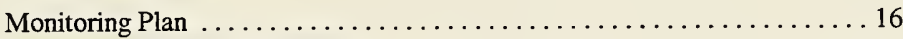

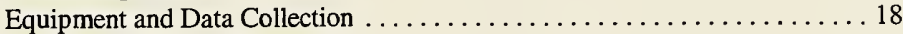

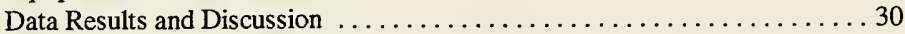

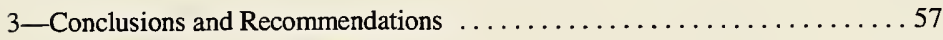

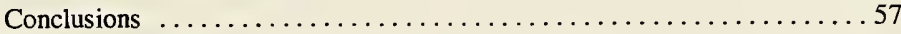

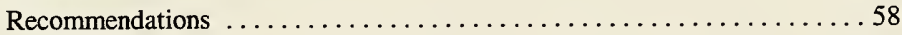

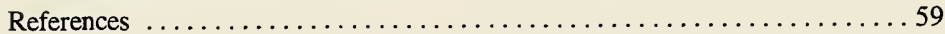

Tables 1-6

Appendix A: Breakwater Topography, $1996 \ldots \ldots \ldots \ldots \ldots \ldots \ldots$ A1

Appendix B: Changes in Breakwater Elevations Between 1994 and 1996 . . . . B1

Appendix C: Breakwater Cross Sections, 1994 and $1996 \ldots \ldots \ldots \ldots \ldots$ C1

SF 298

\section{List of Figures}

Figure 1. Project location $\ldots \ldots \ldots \ldots \ldots \ldots \ldots \ldots \ldots \ldots \ldots \ldots \ldots \ldots$

Figure 2. Layout of St. Paul Harbor $\ldots \ldots \ldots \ldots \ldots \ldots \ldots \ldots \ldots \ldots$

Figure 3. Aerial view of St. Paul Harbor $\ldots \ldots \ldots \ldots \ldots \ldots \ldots \ldots \ldots \ldots \ldots \ldots \ldots \ldots \ldots \ldots$ 
Figure 4. Typical breakwater cross sections $\ldots \ldots \ldots \ldots \ldots \ldots \ldots$

Figure $5 . \quad 3-\mathrm{D}$ model layout $\ldots \ldots \ldots \ldots \ldots \ldots \ldots \ldots \ldots \ldots \ldots \ldots \ldots \ldots$

Figure $6 . \quad$ General view of $3-\mathrm{D}$ model $\ldots \ldots \ldots \ldots \ldots \ldots \ldots$

Figure 7. Layout of recommended $3-\mathrm{D}$ model test plan $\ldots \ldots \ldots \ldots \ldots$

Figure 8. Typical wave patterns for Plan 47; 14-sec, 4.9-m (16-ft) test waves from west $\ldots \ldots \ldots \ldots \ldots \ldots \ldots \ldots \ldots \ldots \ldots \ldots$

Figure 9. Typical current patterns and magnitudes (prototype feet per second) for Plan 47 for test waves from west $\ldots \ldots \ldots \ldots \ldots \ldots 12$

Figure 10. General movement of tracer material and subsequent deposits for Plan 47 for test waves from west-northwest ........... 13

Figure 11. Wave flume cross section $\ldots \ldots \ldots \ldots \ldots \ldots \ldots \ldots \ldots \ldots \ldots \ldots \ldots \ldots \ldots$

Figure 12. Cross section of recommended breakwater $\ldots \ldots \ldots \ldots \ldots \ldots$

Figure 13. Model view of recommended breakwater cross section ........ 15

Figure 14. Prototype gauge locations at St. Paul Harbor ............. 19

Figure 15. Coarse grid used for initial stage of wave hindcast study . . . . 21

Figure 16. Fine-resolution grid used for final stage of wave hindcast study . . 22

Figure 17. Video camera used to obtain runup data $\ldots \ldots \ldots \ldots \ldots \ldots$

Figure 18. Ground control points (GCP's) and profile (PFL) locations established on breakwater .................... 24

Figure 19. View of collection box used for measurement of wave

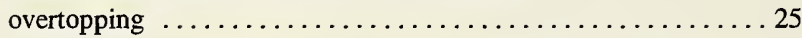

Figure 20. Flow transducers and recorder used to determine overtopping

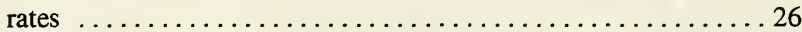

Figure 21. Massive overtopping of St. Paul Harbor main breakwater on

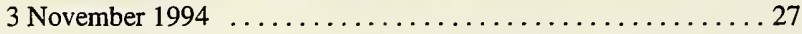

Figure 22. Collapsed apron resulting from 3 November 1994 storm . . . . . . 27

Figure 23. Example of target established on St. Paul breakwater . . . . . . 29

Figure 24. Bathymetry at St. Paul Harbor, September 1986 . . . . . . . 33

Figure 25. Bathymetry at St. Paul Harbor, August 1992 . . . . . . . . . 34

Figure 26. Contours of bathymetric changes between September 1986 and

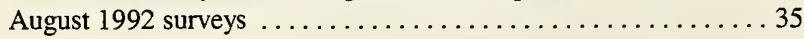

Figure 27. Bathymetry at St. Paul Harbor, July $1995 \ldots \ldots \ldots \ldots \ldots \ldots \ldots$

Figure 28. Contours of bathymetric changes between August 1992 and July

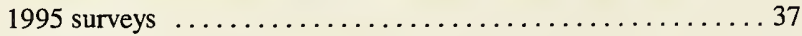

Figure 29. Areas at harbor entrance selected for detailed analysis . . . . . 38 
Figure 30. Detailed bathymetry in Areas A and B for September 1986

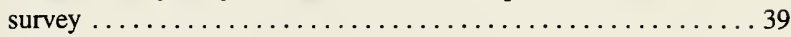

Figure 31. Detailed bathymetry in Areas A and B for August 1992 survey . . 40

Figure 32. Detailed bathymetry in Areas A and B for July 1995 survey . . . . . 41

Figure 33. Cross sections through Area A, Section A-A for 1986, 1992, and

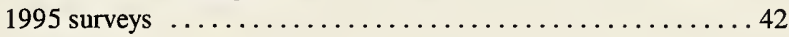

Figure 34. Cross sections through Area B, Section B-B for 1986, 1992, and

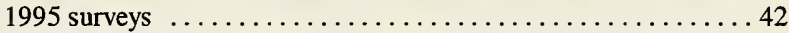

Figure 35. Cross sections through Area A, Section C-C for 1986, 1992, and

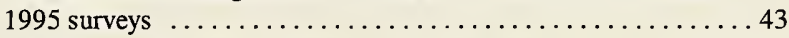

Figure 36. Contours of bathymetric changes in Areas A and B between September 1986 and August 1992 surveys . . . . . . . . . 44

Figure 37. Contours of bathymetric changes in Areas A and B between August 1992 and July 1995 surveys . . . . . . . . . . 45

Figure 38. Contours of bathymetric changes in the lee of the eastern end of the detached breakwater between September 1986 and July 1995 . . 46

Figure 39. Approximate locations of broken/cracked armor stone on outer breakwater during June 1996 survey . . . . . . . . . . . 48

Figure 40. View of broken armor stone on St. Paul Harbor breakwater

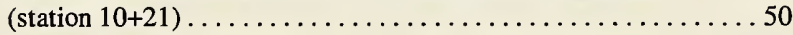

Figure 41. View of broken armor stone on St. Paul Harbor breakwater

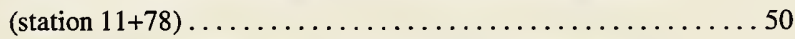

Figure 42. View of broken armor stone on St. Paul Harbor breakwater (station 11+87) . . . . . . . . . . . . . . . . . 51

Figure 43. View of broken armor stone on St. Paul Harbor breakwater (station 17+34) ................................ 51

Figure 44. Locations of monuments and targets for 1994 survey . . . . . . 52

Figure 45. Locations of monuments and targets for 1996 survey . . . . . 52

Figure 46. Example of stereo pair photos for a portion of the breakwater in

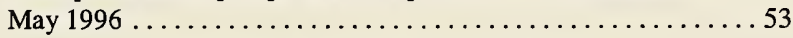

Figure 47. Orthophoto for a portion of the breakwater in May 1996 . . . . . . 54

Figure 48. Point plot map of a portion of the breakwater in May 1996 . . . . 55

Figure A1. Topography of St. Paul Harbor main breakwater, May 1996,

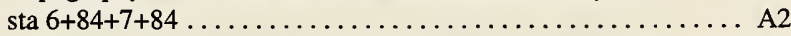

Figure A2. Topography of St. Paul Harbor main breakwater, May 1996,

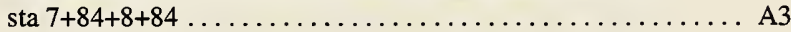

Figure A3. Topography of St. Paul Harbor main breakwater, May 1996,

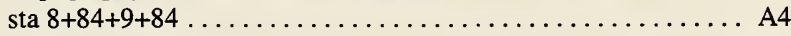


Figure A4. Topography of St. Paul Harbor main breakwater, May 1996,

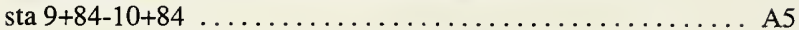

Figure A5. Topography of St. Paul Harbor main breakwater, May 1996,

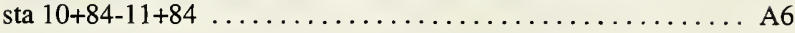

Figure A6. Topography of St. Paul Harbor main breakwater, May 1996,

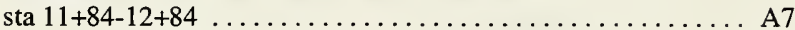

Figure A7. Topography of St. Paul Harbor main breakwater, May 1996,

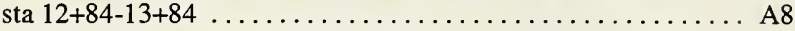

Figure A8. Topography of St. Paul Harbor main breakwater, May 1996, sta $13+84-14+84 \ldots \ldots \ldots \ldots \ldots \ldots \ldots \ldots \ldots \ldots \ldots$ A9

Figure A9. Topography of St. Paul Harbor main breakwater, May 1996,

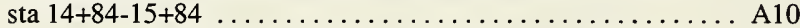

Figure A10. Topography of St. Paul Harbor main breakwater, May 1996, sta $15+84-16+84$

Figure A11. Topography of St. Paul Harbor main breakwater, May 1996, sta $16+84-17+84$

Figure A12. Topography of St. Paul Harbor main breakwater, May 1996, sta $17+84-18+00$

Figure B1. Difference in elevation of St. Paul Harbor main breakwater from May 1994 to May 1996 , sta $6+84-7+84 \ldots \ldots \ldots \ldots \ldots \ldots$ B2

Figure B2. Difference in elevation of St. Paul Harbor main breakwater from May 1994 to May 1996 , sta $7+84-8+84 \ldots \ldots \ldots \ldots \ldots$ B3

Figure B3. Difference in elevation of St. Paul Harbor main breakwater from May 1994 to May 1996 , sta $8+84-9+84 \ldots \ldots \ldots \ldots \ldots$ B4

Figure B4. Difference in elevation of St. Paul Harbor main breakwater from May 1994 to May 1996, sta $9+84-10+84 \ldots \ldots \ldots \ldots \ldots \ldots$ B5

Figure B5. Difference in elevation of St. Paul Harbor main breakwater from May 1994 to May 1996, sta $10+84-11+84 \ldots \ldots \ldots \ldots$. . . . B6

Figure B6. Difference in elevation of St. Paul Harbor main breakwater from May 1994 to May 1996 , sta $11+84-12+84 \ldots \ldots \ldots \ldots \ldots$ B7

Figure B7. Difference in elevation of St. Paul Harbor main breakwater from May 1994 to May 1996, sta $12+84-13+84 \ldots \ldots \ldots \ldots \ldots$ B8

Figure B8. Difference in elevation of St. Paul Harbor main breakwater from May 1994 to May 1996, sta $13+84-14+84 \ldots \ldots \ldots \ldots \ldots$ B9

Figure B9. Difference in elevation of St. Paul Harbor main breakwater from May 1994 to May 1996, sta $14+84-15+84 \ldots \ldots \ldots \ldots \ldots$ B10

Figure B10. Difference in elevation of St. Paul Harbor main breakwater from May 1994 to May 1996 , sta $15+84-16+84 \ldots \ldots \ldots \ldots \ldots$ B1 1 
Figure B11. Difference in elevation of St. Paul Harbor main breakwater from May 1994 to May 1996, sta $16+84-17+84$

Figure B12. Difference in elevation of St. Paul Harbor main breakwater from May 1994 to May 1996 , sta $17+84-18+00 \ldots \ldots \ldots \ldots$ B13

Figure $\mathrm{Cl}$. Cross sections of St. Paul Harbor main breakwater, stas $7+00$

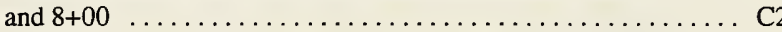

Figure C2. Cross sections of St. Paul Harbor main breakwater, stas $9+00$

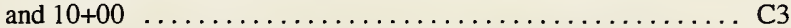

Figure C3. Cross sections of St. Paul Harbor main breakwater, sta $11+00 \ldots$ C4

Figure C4. Cross sections of St. Paul Harbor main breakwater, sta $12+00$. . C5

Figure C5. Cross sections of St. Paul Harbor main breakwater, sta 13+00 . . C6

Figure C6. Cross sections of St. Paul Harbor main breakwater, stas $14+00$

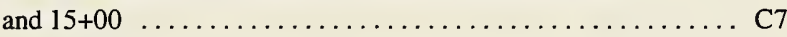

Figure C7. Cross sections of St. Paul Harbor main breakwater, stas $16+00$

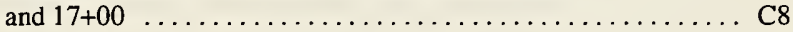

Figure C8. Cross sections of St. Paul Harbor main breakwater, sta $18+00$. . C C9 


\section{Preface}

The study reported herein was conducted as part of the Monitoring Completed Navigation Projects (MCNP) Program (formerly Monitoring Completed Coastal Projects) Program. Work was carried out under Work Unit 11M10, "St. Paul Harbor, Alaska." Overall program management for MCNP is accomplished by the Hydraulic Design Section of Headquarters, U.S. Army Corps of Engineers (HQUSACE). The Coastal and Hydraulics Laboratory (CHL), (in FY 97 the Coastal Engineering Research Center and Hydraulics Laboratory merged into CHL), U.S. Army Engineer Waterways Experiment Station (WES), is responsible for technical and data management and support for HQUSACE review and technology transfer. Program Monitors for the MCNP program are Messrs. John $\mathrm{H}$. Lockhart, Jr., Barry W. Holliday, and Charles B. Chesnutt (HQUSACE). The Program Manager is Ms. Carolyn M. Holmes (CHL).

The work was conducted during the period July 1993 through June 1996 under the general supervision of Dr. James R. Houston, Mr. Charles C. Calhoun, Jr., Director and Assistant Director, CHL, and under the direct supervision of Messrs. C. E. Chatham, Jr., Chief, Wave Dynamics Division, and Dennis G. Markle, Chief, Wave Processes Branch, CHL. Principal investigators for the study were Mr. Robert R. Bottin, Jr., Research Physical Scientist, CHL, and Mr. Kenneth J. Eisses, Hydraulic Engineer, U.S. Army Engineer District, Alaska (CENPA). This report was prepared by Messrs. Bottin and Eisses.

Limited ground surveys, aerial photography, and photogrammetric analysis of the breakwater were conducted by Richard B. Davis, Inc., Smith River, CA, and bathymetric surveys of the harbor were conducted by LCMS Limited, Inc., Anchorage, AK, under contract to the Corps of Engineers. Acknowledgements also are extended to the following for their contributions during the study, as noted:

Surveys of armor stone quality and stability: Ms. Holmes, Messrs. Bottin, Larry Tolliver, Gordon Harkins, Etienne Trahan, Brian Marble, and David Ballard, CHL; Messrs. Eisses, Carl Stormer, John Burns, Alan Jeffries, and Jerry Raychel, CENPA

Geologic assessment of armor stone quality and durability: Messrs. David Marcus and Shannon Chader, U.S. Army Engineer District, Buffalo 
Preparation of site for overtopping data: Messrs. Bottin, Tolliver, Harkins, Vince Durman, Frank James, and Tim Conrad, WES

Deployment of prototype gauges: Messrs. William Kucharski, Chuck Mayers, and Jodie Landreneau, CHL

Development of wave runup methodology: Mr. Kent Hathaway, CHL

Collection of wave runuplovertopping data: Messrs. David Daily, Don Ward, David Goodin, and Dr. Jimmy Fowler, WES; and Messrs. Jeffries and Harlan Legare, CENPA

Analysis of data: Messrs. Bottin, Acuff, Tolliver, Harkins, and Hathaway, CHL

Wave hindcast study: Ms. Lori Hadley, CHL

Director of WES during the investigation and publication of this report was Dr. Robert W. Whalin. Commander was COL Bruce K. Howard, EN.

The contents of this report are not to be used for advertising, publication, or promotional purposes. Citation of trade names does not constitute an official endorsement or approval of the use of such commercial products. 


\section{Conversion Factors, Non-SI to SI (Metric) Units of Measurement}

Non-SI units of measurement used in figures, plates, and tables of this report can be converted to SI (metric) units as follows:

\begin{tabular}{|l|l|l||}
\hline Multiply & By & To Obtain \\
\hline \hline acres & 4046.856 & square meters \\
\hline cubic feet per second & 28.32 & liters per second \\
\hline cubic yards & 0.7646 & cubic meters \\
\hline degrees (angle) & 0.01745329 & radians \\
\hline feet & 30.48 & centimeters \\
\hline feet & 0.3048 & meters \\
\hline feet per second & 0.3048 & meters per second \\
\hline inches & 2.54 & centimeters \\
\hline square feet & 0.9290304 & square meters \\
\hline square miles (U.S. statute) & 2.589988 & square kilometers \\
\hline tons (2.000 pounds, mass) & 907.1847 & kilograms \\
\hline \hline
\end{tabular}




\section{Introduction}

\section{Monitoring Completed Navigation Projects Program}

The goal of the Monitoring Completed Navigation Projects (MCNP) Program (formerly Monitoring Completed Coastal Projects Program) is the advancement of coastal engineering technology. It is designed to determine how well projects are accomplishing their purposes and are resisting attacks of the physical environment. These determinations, combined with concepts and understanding already available, will lead to more credibility in predicting engineering solutions to coastal problems; to strengthening and improving design criteria and methodology; to improving construction practices and cost-effectiveness; and to improving operation and maintenance techniques. Additionally, the monitoring program will identify where current technology is inadequate or where additional research is required.

To develop the direction for the program, the Corps of Engineers established an ad hoc committee of coastal engineers and scientists. The committee formulated the program's objectives, developed its operational philosophy, recommended funding levels, and established criteria and procedures for project selection. A significant result of their efforts was a prioritized listing of problem areas to be addressed, essentially a listing of the program's areas of interest. Areas of interest for the MCNP program are shown in Table 1.

Corps coastal offices are invited to nominate projects for inclusion in the monitoring program as funds become available. A selection committee, comprised of members of the MCNP Program Field Review Group (representatives from District and Division offices) and civilian members of the Coastal Engineering Research Board, reviews and prioritizes the projects nominated. The prioritized list is reviewed by the Program Monitors at Headquarters, U.S. Army Corps of Engineers (HQUSACE). Final selection is based on this prioritized list, national priorities, and the availability of funding.

The overall monitoring program is under the management of the U.S. Army Engineer Waterways Experiment Station (WES), Coastal and Hydraulics Laboratory (CHL), with guidance from HQUSACE. Operation of individual 
monitoring projects is a cooperative effort between the submitting District/Division 1 office and CHL. Development of monitoring plans and the conduct of data collection and analyses are dependent upon the combined resources of $\mathrm{CHL}$ and the District/Divisions. St. Paul Harbor, Alaska, was nominated and subsequently approved for inclusion in the monitoring program in 1992.

\section{Project Location and History}

St. Paul Island is the northernmost and largest island of the Pribilofs in the eastern Bering Sea (Figure 1) with a land area of $114 \mathrm{sq} \mathrm{km} \mathrm{(44} \mathrm{sq} \mathrm{miles)}{ }^{1}$. The Pribilofs are of volcanic origin, and St. Paul is composed predominantly of volcanic materials in the form of lava flows and loose cinders with sandy deposits. The west and southwest portions of the island are relatively high and mountainous, with precipitous cliffs along the coast. The remainder of the island is relatively low and rolling with a number of extinct volcanic peaks scattered throughout. Only two of the Pribilof Islands are populated, St. Paul with 800 people and St. George with 290 people. Two-thirds of the St. Paul population is Alaskan Native.

The Pribilof Islands support large populations of birds, mammals, fish, and invertebrates. The Pribilofs are the primary breeding ground for northern fur seals where approximately two-thirds of the world's population (1.3 to 1.4 million) migrate annually (U.S. Army Engineer District, Alaska 1981). More than a quarter million seabirds nest on St. Paul Island each year, mainly along the coastal cliffs. The uplands are inhabited by songbirds, white and blue foxes, and a transplanted herd of approximately 250 reindeer. The island is treeless and covered with grasses, sedges, and wildflowers. The eastern Bering Sea near St. Paul supports populations of shrimp, commercially harvestable species of crab, and bottom fish.

The city of St. Paul is located on a cove on the southern tip of the island and is the island's only settlement. The islands were originally settled by the Russians to harvest fur seals. The treaty for the purchase of Alaska from Russia by the United States in 1867 placed the Pribilofs under United States control. The National Marine Fisheries Service (NMFS) and its predecessor Federal agencies were responsible for the fur seal industry in the Pribilofs since 1911, managing the harvest according to a series of international agreements between the United States, Canada, Japan, and the Soviet Union. In 1983, the harvest of fur seals was discontinued due to a seal harvest moratorium. The NMFS terminated administration, management, and employment at St. Paul. This event had a significant adverse impact on the economy, and the standard of living could not be maintained. At that time the village had no other economic base, no harbor infrastructure, inadequate and unpermitted utilities, overcrowded housing, high unemployment, and limited air and vessel transportation. Development of a harbor, and associated marine-related

\footnotetext{
1 Units of measurement in the text of this report are shown in SI (metric) units, followed by non-SI (British) units in parentheses. In addition, a table of factors for converting non-SI units of measurement used in figures in this report to SI units is presented on page $x$.
} 


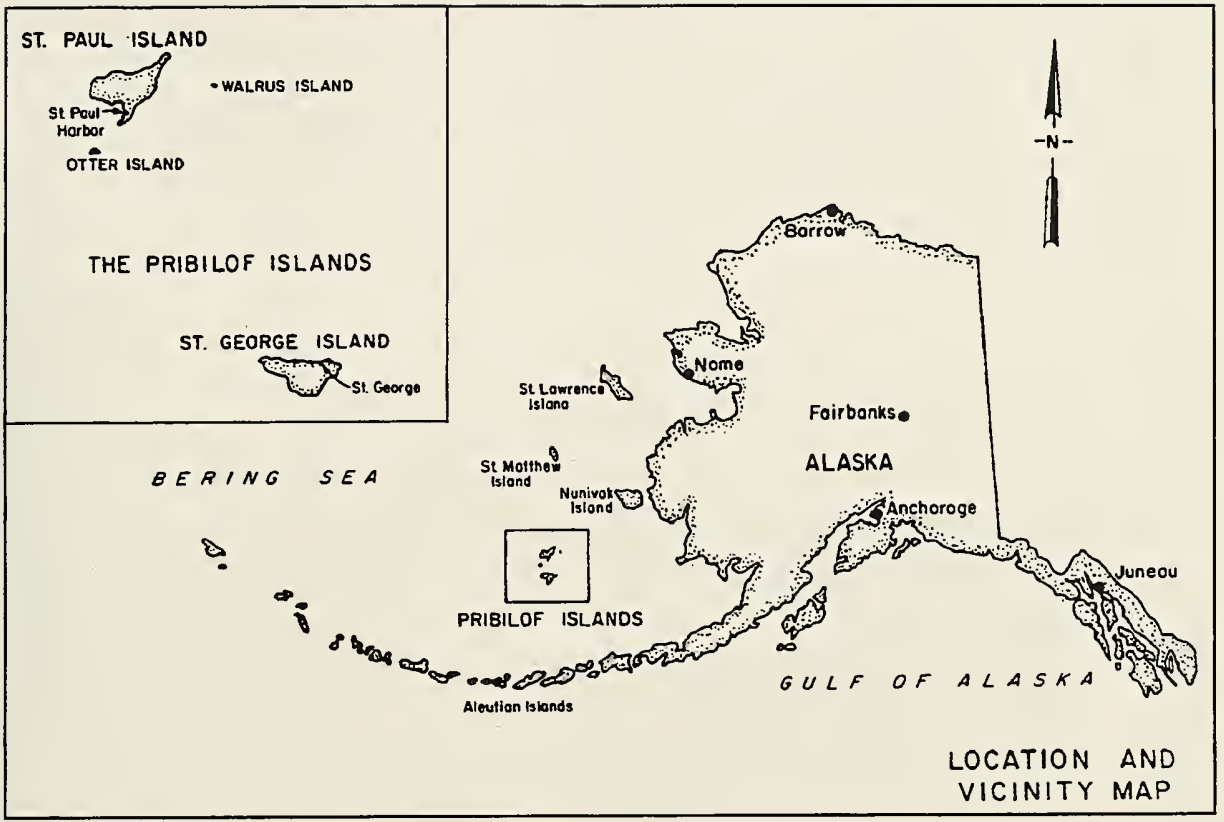

Figure 1. Project location

industries, fulfilled the need for new sources of employment and income on the island.

\section{Harbor Development}

A breakwater was constructed at St. Paul in Village Cove during 1984, but subsequently failed during the storm season. A new breakwater was designed and constructed by Tetra Tech, Inc., consultants to the City of St. Paul (Tetra Tech, Inc. 1987). The structure was $229 \mathrm{~m}(750 \mathrm{ft})$ in length and functioned well, with regard to stability, during the 1985 and 1986 winter seasons. A 61-m-long (200-ft-long), vertical-wall dock was subsequently installed in the lee of the breakwater to accommodate fishing vessels. The breakwater, however, was not of sufficient length to provide wave protection to vessels using the dock, particularly during storm events.

In 1989 , construction of the current harbor was completed. A layout of the harbor is shown in Figure 2. It consists of a 549-m-long (1,800-ft-long) main breakwater, a 296-m-long (970-ft-long) detached breakwater, and space for $274 \mathrm{~m}$ $(900 \mathrm{ft})$ of docks on the lee side of the main breakwater. The main breakwater, 


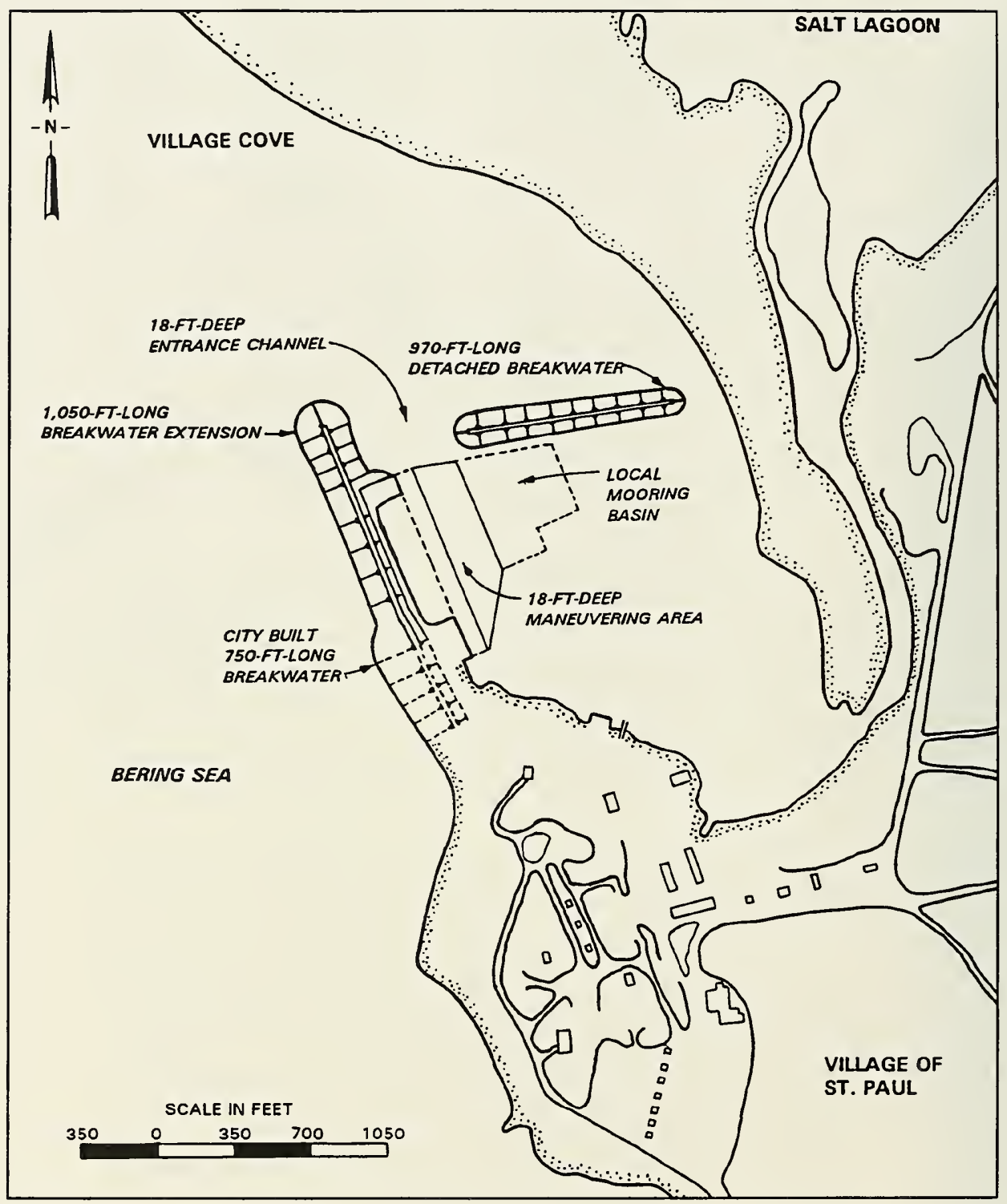

Figure 2. Layout of St. Paul Harbor 
generally, follows the $-7.6-\mathrm{m}(-25-\mathrm{ft})^{1}$ contour in Village Cove and results in a harbor with 32,375 to $40,470 \mathrm{sq} \mathrm{m}$ ( 8 to 10 acres) of area, and water depths of 5.5 to $7.6 \mathrm{~m}$ ( 18 to $25 \mathrm{ft})$ on the lee side of the breakwater. The center line of the detached breakwater makes an interior angle of $75 \mathrm{deg}$ with the main structure at sta $17+00$, and provides a $91-\mathrm{m}$-wide (300-ft-wide) harbor entrance. A 61-m-wide (200-ft-wide) opening between the eastern end of the detached breakwater and the shore is maintained to enhance harbor circulation. Figure 3 is an aerial photograph of the existing St. Paul Harbor.

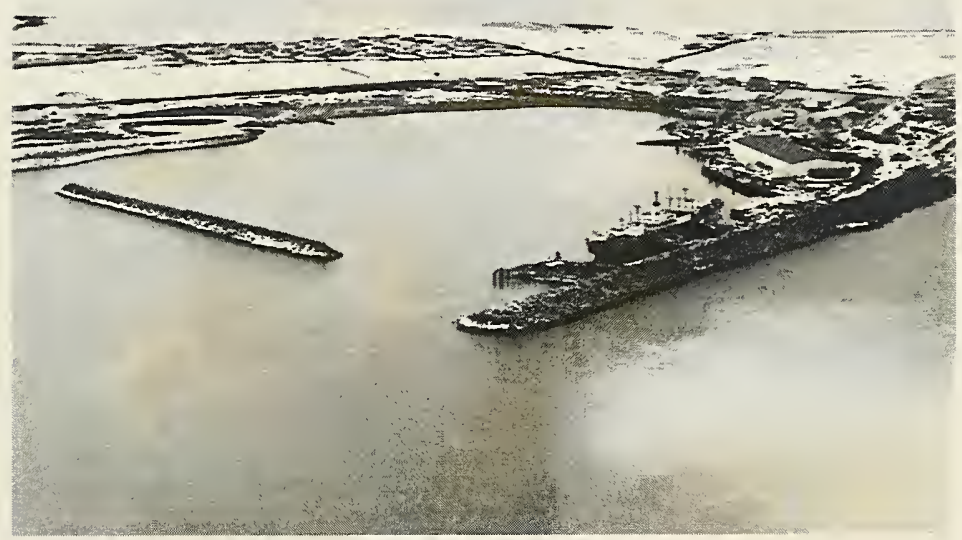

Figure 3. Aerial view of St. Paul Harbor

The main breakwater has a crest elevation (el) of $+11.3 \mathrm{~m}(+37 \mathrm{ft})$ from sta $7+50$ to a point approximately $15.2 \mathrm{~m}(50 \mathrm{ft})$ north of the northernmost dock. The remaining portion of the structure has a crest el of $+9.1 \mathrm{~m}(+30 \mathrm{ft})$. Armor stone used on the breakwater trunk was $16,330 \mathrm{~kg}$ ( 18 ton), and $21,770-\mathrm{kg}$ (24-ton) armor stone was used on the head. The slope of the trunk is $1 \mathrm{~V}: 2 \mathrm{H}$ with a $1 \mathrm{~V}: 3 \mathrm{H}$ slope around the breakwater head. A roadway was constructed on the lee side of the main breakwater adjacent to the proposed docks. The detached breakwater has a crest el of $+5.5 \mathrm{~m}(+18 \mathrm{ft})$ with 4,535-kg (5-ton) armor stone placed on a slope of $1 \mathrm{~V}: 1.5 \mathrm{H}$. Typical cross sections of the main and detached breakwater trunks are shown in Figure 4. Prior to construction of the 1989 improvements, both twodimensional (Ward 1988) and three-dimensional (Bottin and Mize 1988) hydraulic model investigations were conducted at WES to optimize the structural and functional design of the harbor.

\footnotetext{
${ }^{1}$ All contours and elevations cited herein are in meters (feet) referred to mean lower low water (mllw) unless otherwise noted.
} 


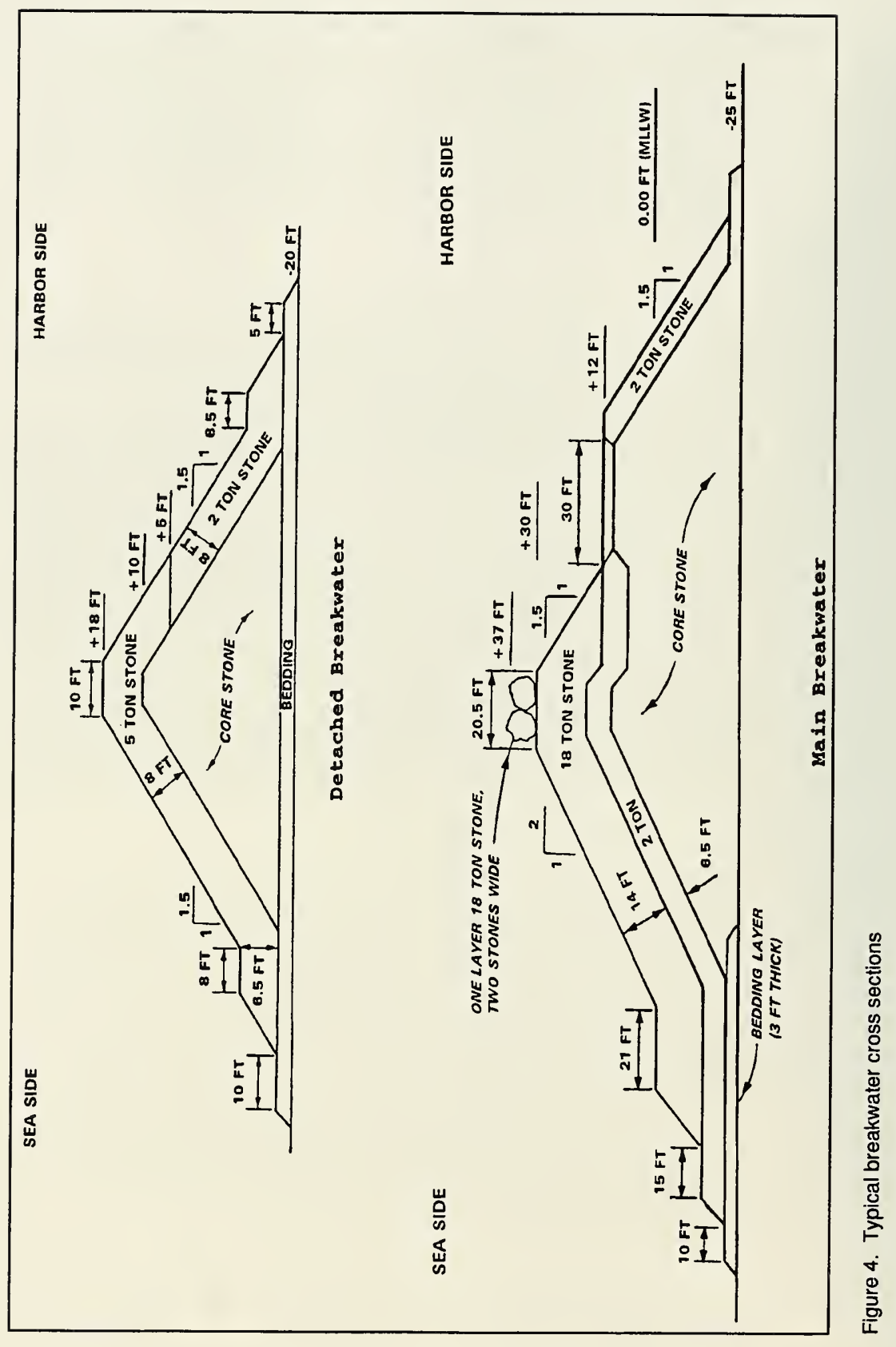




\section{Hydraulic Model Studies of the Harbor}

\section{Three-dimensional (3-D) model study}

During 1987, a 3-D model study of St. Paul Harbor, AK, (Bottin and Mize 1988) was conducted at WES to:

a. Study wave and shoaling conditions for the existing harbor.

b. Determine the most economical breakwater extension configuration that would provide adequate wave protection to the proposed mooring area and docking facilities.

c. Provide qualitative information on the effects of the breakwater extension on sediment movement adjacent to the harbor and shoreline of Village Cove.

d. Develop remedial plans for the alleviation of undesirable conditions as necessary.

The St. Paul Harbor model (Figure 5) was constructed to a linear scale of 1:75, model to prototype. It reproduced approximately $4,115 \mathrm{~m}(13,500 \mathrm{ft})$ of the St. Paul Island shoreline and included the existing harbor (located in Village Cove), and underwater topography in the Bering Sea to an offshore depth of $12.2 \mathrm{~m}$ (40 ft). A small connecting channel to a salt lagoon (located east of the harbor) was also included in the model as well as the tidal prism of the salt lagoon. The total area reproduced in the model was approximately $1,500 \mathrm{sq} \mathrm{m}(16,000 \mathrm{sq} \mathrm{ft})$, representing about $8.3 \mathrm{sq} \mathrm{km}$ ( $3.2 \mathrm{sq}$ miles) in the prototype. Figure 6 is a general view of the model.

Model tests were conducted for 59 improvement plans with variations that entailed changes in the length, alignment, and/or crest el of breakwater extensions, breakwater spurs, and a detached breakwater. An 18.3-m-long (60-ft-long) unidirectional, spectral wave generator, an automated data acquisition and control system, and a crushed coal tracer material were utilized in model operation. A layout of the recommended plan (Plan 47) is shown in Figure 7. The most notable difference between the recommended model plan and the breakwater configuration constructed in the prototype was the width of the navigation opening. The model plan consisted of a 76.2-m-wide (250-ft-wide) entrance opening; however, a 91.4-m-wide (300-ft-wide) opening was constructed in the prototype to enhance ease of navigation in and out of the harbor. Also, the length of the detached breakwater tested in the model was $335 \mathrm{~m}(1,100 \mathrm{ft})$ as opposed to the $296-\mathrm{m}$-long (970-ft-long) structure constructed in the prototype.

Wave height tests and wave patterns were obtained for existing conditions and the 59 test plans. Some plans were limited to the most critical direction of wave approach; however, the most promising ones were tested comprehensively for waves from five directions. The U.S. Army Engineer District, Alaska (CENPA) specified that for an improvement plan to be acceptable, maximum significant wave heights 


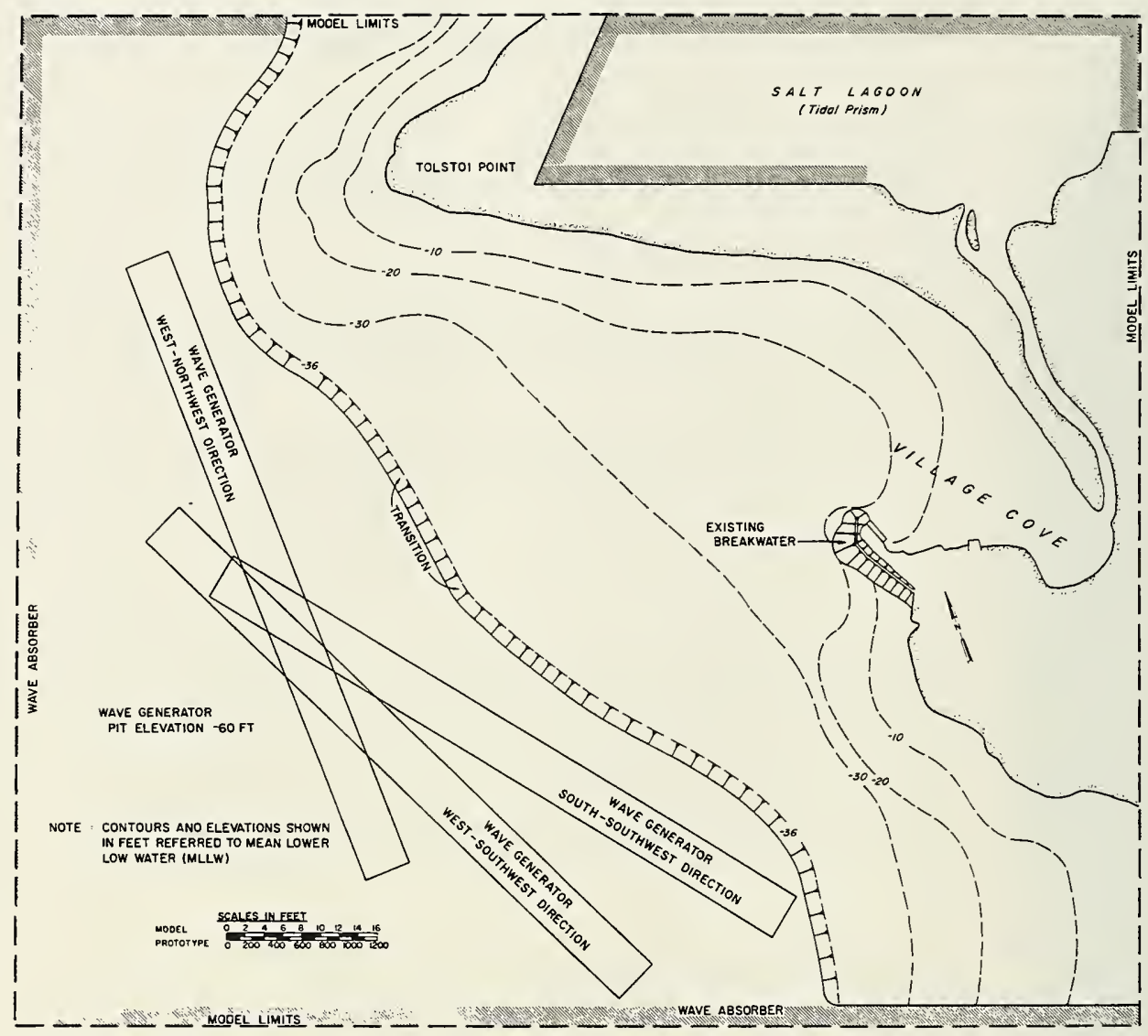

Figure 5. 3-D model layout

were not to exceed $0.76 \mathrm{~m}(2.5 \mathrm{ft}$ ) in a specified mooring area (area in lee of detached breakwater). For Plan 47, the wave height criterion was exceeded by only $0.03 \mathrm{~m}(0.1 \mathrm{ft})$ for the most severe incident storm wave conditions. Plan 47 was recommended for construction based on wave protection, navigation, and costs. Typical wave patterns for Plan 47 are shown in Figure 8.

Wave-induced current patterns and magnitudes were determined at selected locations in the model by timing the progress of a dye tracer relative to known distances on the model surface. Test results for Plan 47 indicated that currents will move southerly along the shoreline north of the harbor. Some will enter the harbor between the opening at the shoreward end of the detached breakwater and the shoreline. These currents will move in a clockwise direction in the harbor and exit 


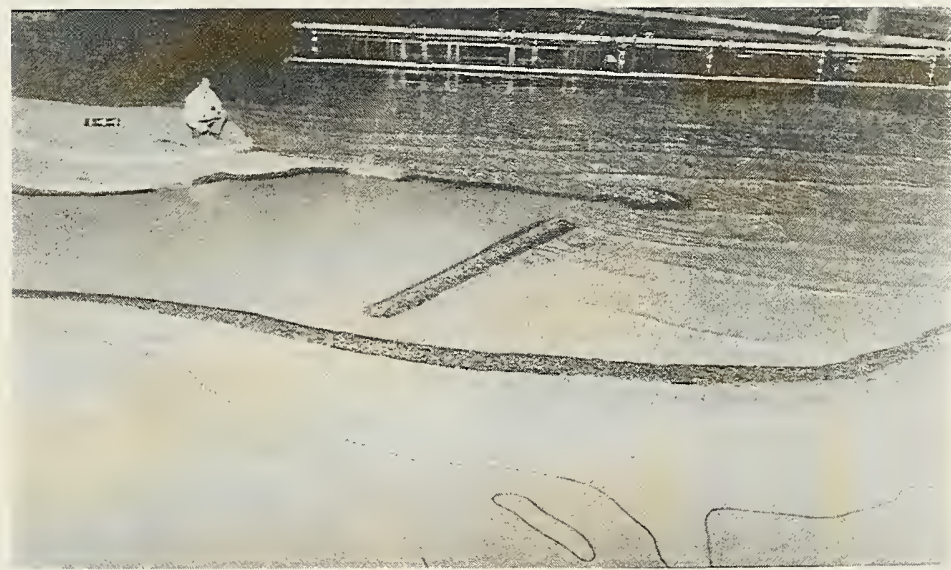

Figure 6. General view of 3-D model

through the entrance, thus providing harbor circulation. Other currents will move westerly along the north side of the detached breakwater, then seaward across the harbor entrance. Maximum velocities of $2.2 \mathrm{mps}$ ( $7.2 \mathrm{fps}$ ) occurred inside the harbor during periods of severe storm wave attack. Typical current patterns and magnitudes for the recommended improvement plan are shown in Figure 9.

A crushed coal tracer material was used in the model to determine qualitatively the general movement and subsequent deposits of sediment. The material was selected in accordance with the scaling relations of Noda (1972). For Plan 47, sediment generally moved southerly along the shoreline and some material migrated into the harbor through the opening between the detached breakwater and the shoreline. Some material also moved westerly along the seaside of the detached breakwater and migrated seaward across the harbor entrance. Typical tracer movement and subsequent deposits are shown in Figure 10. Material penetrating into the harbor did not deposit in the proposed mooring area in the lee of the detached breakwater.

\section{Two-dimensional (2-D) model study}

During 1987, a 2-D model study of proposed breakwater extensions at St. Paul Harbor, AK, (Ward 1988) was conducted at WES to:

a. Evaluate overall stability of the proposed breakwater.

b. Determine wave runup and overtopping characteristics when the breakwater is exposed to a range of design wave and water level conditions. 


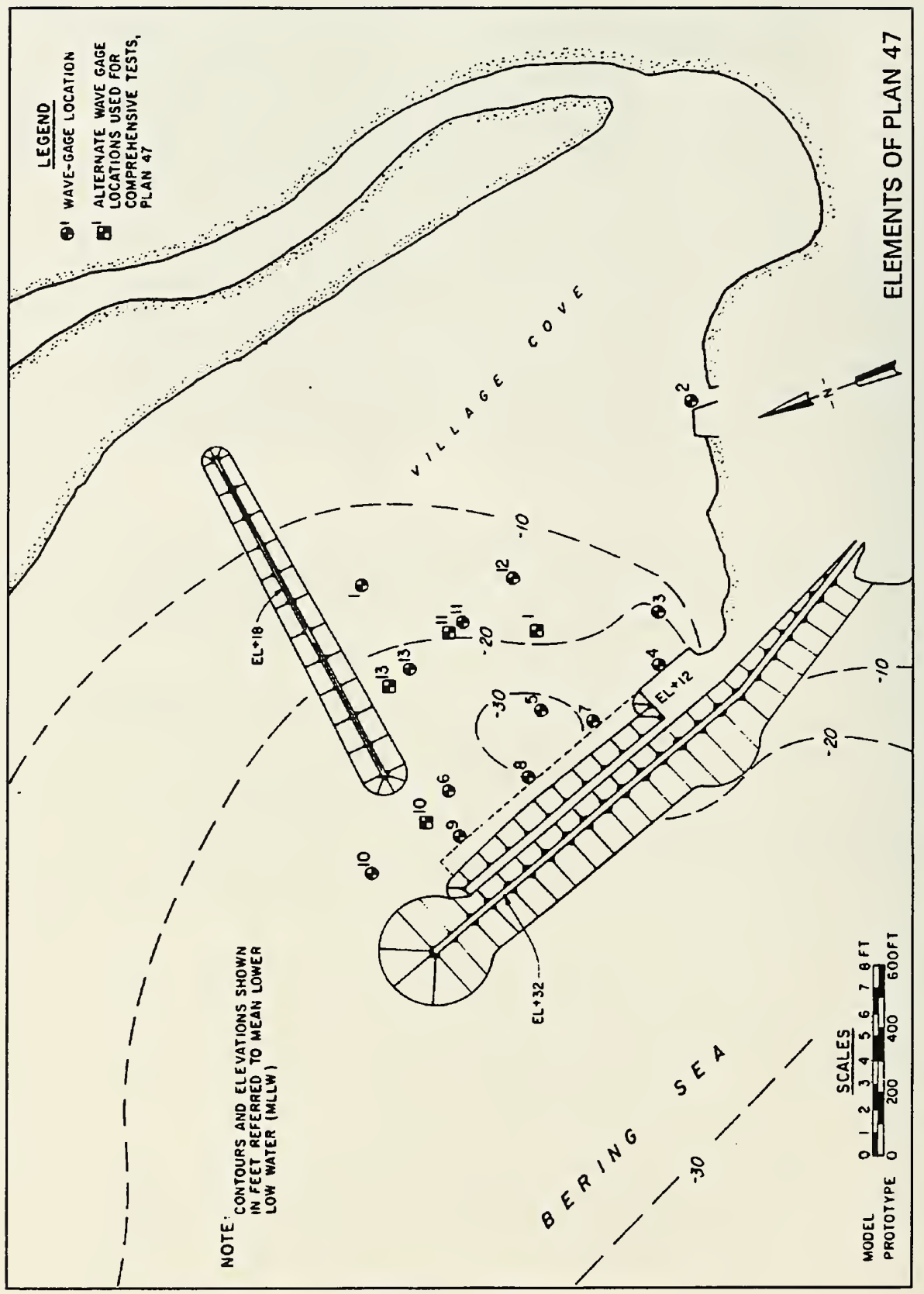

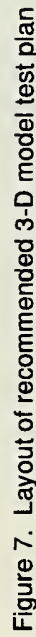




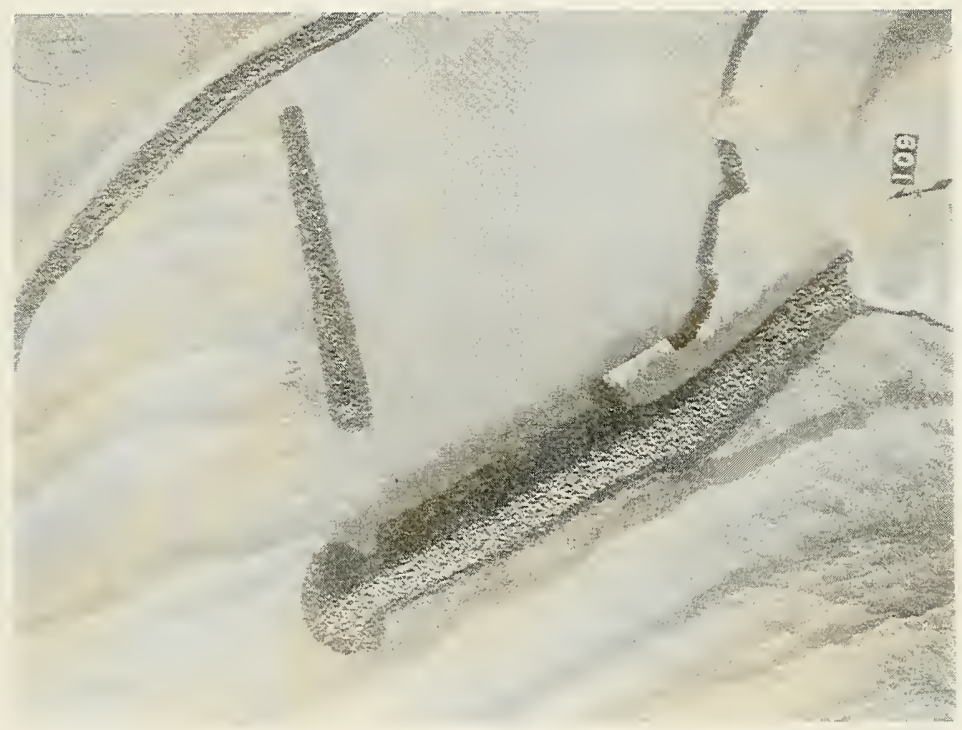

Figure 8. Typical wave patterns for Plan 47; 14-sec, 4.9-m (16-ft) test waves from west

c. Make revisions to the proposed breakwater design (increase or decrease armor stone size and/or modify structure geometry) based on results of initial tests.

d. Test adequacy of the revised design when exposed to the same design wave and water level conditions.

All 2-D model tests were conducted in a 36.3-m-long, 1.5-m-wide, 1.2-m-deep (119-ft-long, 5-ft-wide, 4-ft-deep) wave flume equipped with a wave generator capable of producing monochromatic waves of various periods and heights. A cross section of the wave flume is shown in Figure 11. Tests were conducted at a linear scale of $1: 38.5$, model to prototype.

Model tests were conducted for five breakwater cross-section plans. These plans were subjected to test waves ranging from 11 to $16 \mathrm{sec}$ in period and from 4.8 to $7.3 \mathrm{~m}$ ( 15.6 to $24.1 \mathrm{ft})$ in height. Still-water levels of 0.0 and $+1.5 \mathrm{~m}(0.0$ and $+5.0 \mathrm{ft}$ ) were used.

Tests were conducted to determine the stability of the breakwater cross sections. Moderate wave conditions (11-sec waves) were initially run to shake down the structure. This test represents typical prototype consolidation caused by wave action during construction. The structure then was subjected to maximum breaking wave conditions (11- and 14-sec waves) to determine its stability. Survivability tests then were conducted using maximum breaking waves with a 16 -sec period. In 


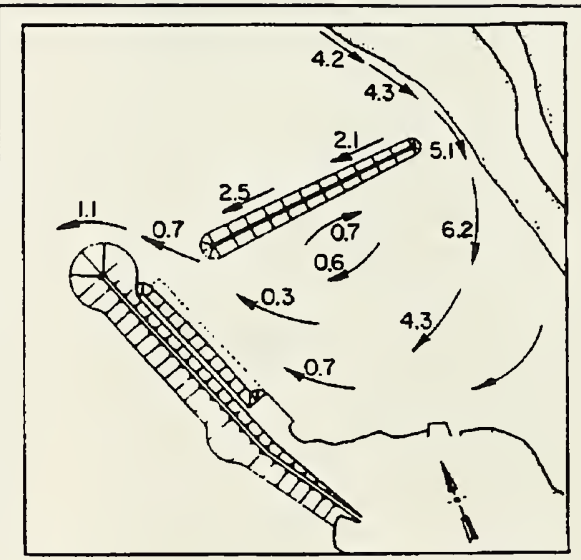

a. 6-sec, 10-ft test waves

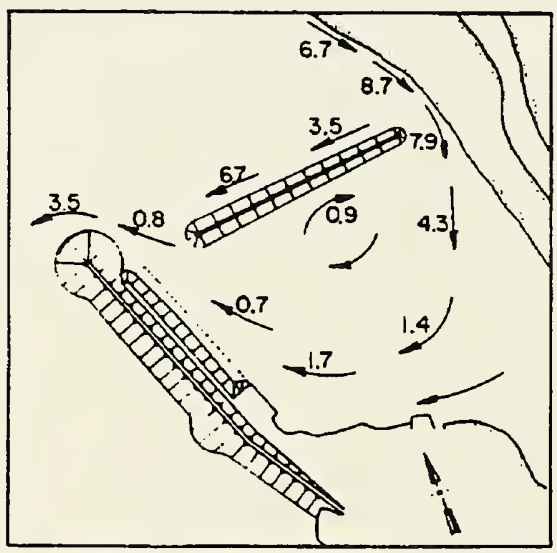

c. 12-sec, 16-ft test waves

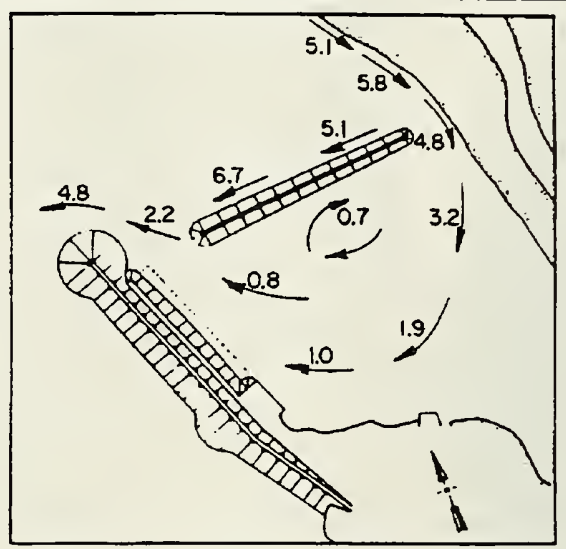

b. 10-sec, 19-ft test waves

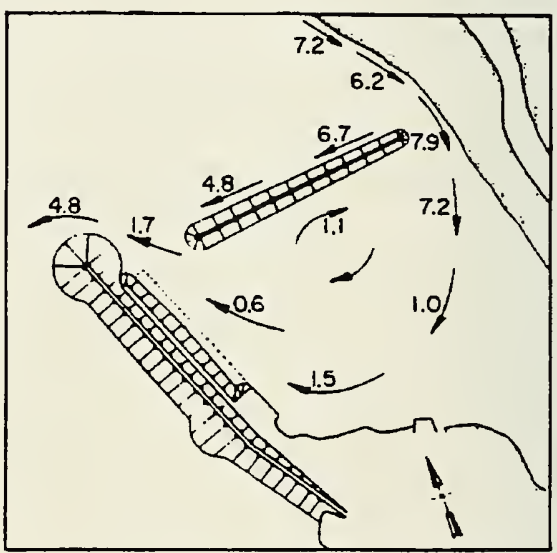

d. 16-sec, 19-ft test waves

Figure 9. Typical current patterns and magnitudes (prototype feet per second) for Plan 47 for test waves from west

addition, toe stability tests were conducted for the cross sections for 14- and 16-sec wave conditions. Wave runup and overtopping were measured during stability and survivability tests for each plan, and additional overtopping tests were conducted for the more promising breakwater sections. 


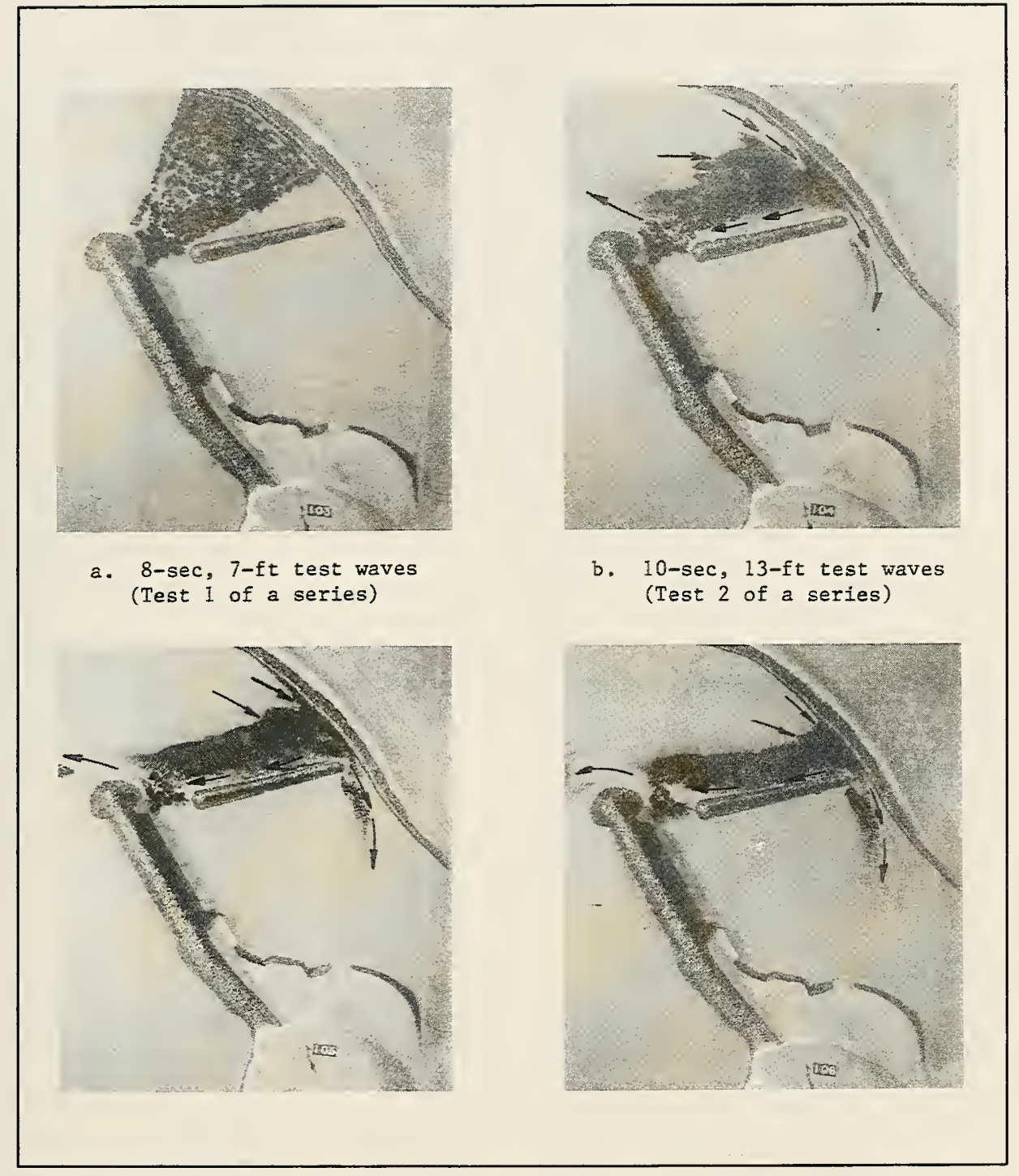

Figure 10. General movement of tracer material and subsequent deposits for Plan 47 for test waves from west-northwest 


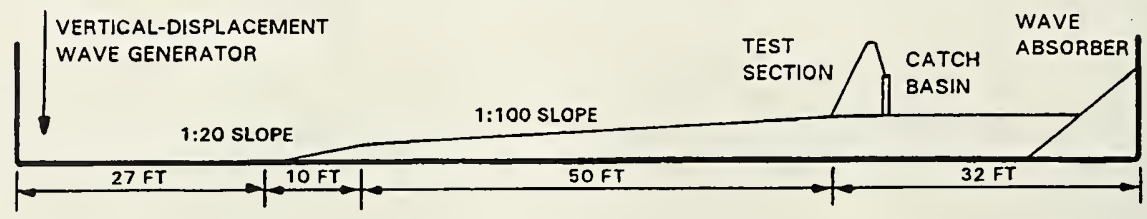

Figure 11. Wave flume cross section

The recommended breakwater plan (Figure 12) demonstrated acceptable stability on the crown and sea-side slope. It was recommended that placed-stone construction techniques be used during prototype construction and that 50 percent of the stone used in the primary armor layers be parallelepiped in shape and the remaining stones be rough angular in shape. Also, the two stone shapes should be kept wellmixed on the structure. It was also noted that the sea-side toe should be constructed with the full weight range of $16,330-\mathrm{kg}$ (18-ton) stone, and care should be taken to ensure good construction placement of the randomly placed toe stones. The placement of a row of $16,330-\mathrm{kg}$ (18-ton) stone ( 2 stones wide) was recommended on the crest of the structure to reduce overtopping rates to within acceptable levels. These stones should be placed with the long axis of the stones parallel to the longitudinal axis of the breakwater. A model view of the recommended plan is shown in Figure 13.

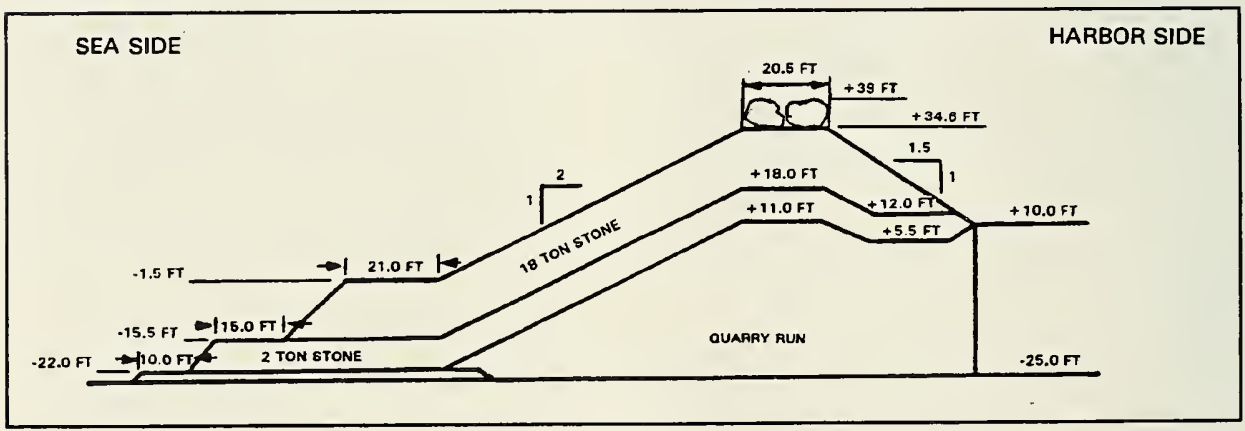

Figure 12. Cross section of recommended breakwater

The recommended breakwater plan tested in the 2-D model differed slightly from the design cross section. The underlayer stone was constructed to its design el and two layers of $16,330-\mathrm{kg}$ (18-ton) armor stone were specially placed. The design

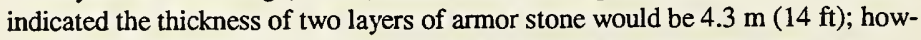
ever, after placement in the model, surveys indicated the thickness was $5.1 \mathrm{~m}$ $(16.6 \mathrm{ft})$. This resulted in a crest el of $+10.5 \mathrm{~m}(+34.6 \mathrm{ft})$ for the primary armor layer as opposed to the $+9.8-\mathrm{m}(+32-\mathrm{ft})$ design el. After placement of the extra layer of armor stones on the crest (with the long axis of the stone parallel to the 


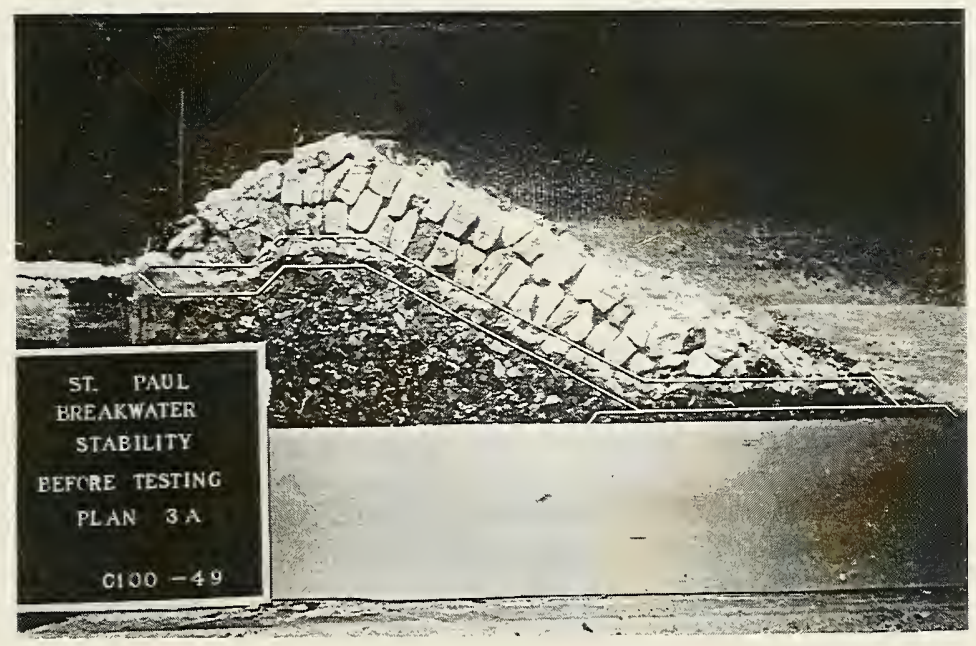

Figure 13. Model view of recommended breakwater cross section

longitudinal axis of the breakwater) the el of the top of the breakwater was $+11.9 \mathrm{~m}$ $(+39 \mathrm{ft})$. The design of the breakwater actually constructed at St. Paul Harbor

(Figure 4) was $+9.1 \mathrm{~m}(+30 \mathrm{ft})$ for the primary armor layer and $+11.3 \mathrm{~m}(+37 \mathrm{ft})$ for the layer of armor stone (two stones wide) on the crest. 


\section{Monitoring Program}

\section{Monitoring Plan}

A monitoring plan was developed prior to monitoring the St. Paul Harbor site. During the development of the monitoring plan specific hypotheses to be tested were laid out. The hypotheses to be tested are shown below:

a. The improvements constructed at St. Paul Harbor, Alaska, in 1989 will result in a functional harbor considering wave heights, current circulation patterns and magnitudes, and shoaling protection.

b. The St. Paul Harbor improvements constructed in 1989 will be structurally sound.

c. The two- and three-dimensional model investigations accurately predicted prototype performance.

d. Sediment will deposit in the harbor via the opening between the detached breakwater and the shoreline, but deposits will not occur in the proposed mooring areas.

e. From breakwater runup and overtopping data, error ranges predicted from the Shore Protection Manual (1984) for the site-specific, two-dimensional model tests for St. Paul may be determined.

The objective of the monitoring program was to determine if the harbor and its structures were performing (both functionally and structurally) as predicted by the model studies used for the project design. Wave, current, and bathymetry measurements at the project site would determine the effectiveness of the functional design aspects. Ground-based surveys and photogrammetric flights of the main breakwater would reveal its structural response to the wave environment. Runup and overtopping rates would be secured and compared to values obtained in the twodimensional model study and values computed from guidance provided in the Shore Protection Manual (1984). These unique prototype measurements would aid in refining the design predictions of runup and overtopping, which in turn would aid in future economic, structurally sound, and functional breakwater designs. 
Elements of the monitoring plan included data collection of waves, both inside and outside the harbor, currents inside the harbor, water levels, bathymetry in and adjacent to the harbor, wave runup heights on the breakwater, wave overtopping rates, and ground and photogrammetric surveys of the main breakwater, as well as surveys of armor stone quality. More detailed information relative to the elements of the monitoring plan is provided in the following subparagraphs.

\section{Wave, tide, and current data collection}

A directional wave gauge, also capable of determining water level measurements, was to be deployed seaward of the harbor in a water depth of approximately $13.1 \mathrm{~m}(40 \mathrm{ft})$. Estimates of deep-water waves and wave conditions at the main breakwater would be determined based on results of the three-dimensional harbor model tests and the numerical Regional Coastal Processes Wave (RCPWAVE) transformation model (Ebersole 1985) which was conducted prior to the physical model investigation. A prototype wave gauge was not recommended in the immediate vicinity of the breakwater since the data would be contaminated by wave reflections. A nondirectional pressure wave gauge also would be installed adjacent to the dock to measure wave conditions inside the harbor. These values would be compared to model test results. In addition, an electromagnetic current meter would be installed inside the harbor to measure wave-induced current magnitudes. These values would be compared to those predicted in the three-dimensional model investigation for measured incident wave conditions.

\section{Collection of wave runup and overtopping data}

Graduations would be painted at certain locations up the breakwater's armor stone face and videotape footage would be obtained periodically during the course of the monitoring effort to record wave runup. To determine wave overtopping rates, a collection box would be prefabricated and shipped to St. Paul for assembly on site. Overtopping volumes would be measured with flow transducers. For mild overtopping, rates were to be calculated based on flow through a trench on the lee side of the breakwater.

\section{Bathymetric data collection}

Bathymetric data were available both prior to and after breakwater construction. Another set of data was to be obtained near the end of the monitoring effort to determine if bathymetric conditions had appeared to stabilize.

\section{Ground-based surveys}

Targets were to be located along the crest of the main breakwater and elevation data obtained periodically during the monitoring effort to determine if settlement of 
the structure was occurring. An inventory of broken/cracked armor units also was to be conducted to determine armor stone quality.

\section{Photogrammetry}

Low-altitude, aerial photographs, at a scale of approximately $2.5 \mathrm{~cm}=6 \mathrm{~m}$ ( 1 in. $=20 \mathrm{ft}$ ) were to be secured for the main breakwater. The photographs were to be obtained from a helicopter with at least a 60 -percent overlap for stereo viewing. From the stereo pairs, a rectified map would be prepared using the ground elevations obtained at the targeted capstones as a basis for verification. From these rectified photos, $\mathrm{x}, \mathrm{y}$, and $\mathrm{z}$ coordinates for any point on any armor stone could be provided from three-dimensional stereo plotters. These photos were to be obtained both early and late during the monitoring to determine movement of units above the water. Base conditions would be established from which to evaluate the structure in the future to determine its long-term stability response in this extremely hostile wave environment.

Since extreme wave conditions generally occur at St. Paul Harbor on an annual basis, only 1 year of wave, current, runup, and overtopping data collection was proposed for these elements. These data would be collected during the winter season (mid-October through March time frame). In general, most of the elements of the monitoring plan were completed as proposed. However, changes in procedures, techniques, etc. were made in some cases during actual monitoring.

\section{Equipment and Data Collection}

Monitoring of St. Paul Harbor, Alaska, was conducted during the period July 1993 through June 1996. Actual elements of the monitoring program included prototype wave gauging, wave hindcast study, wave runup, wave overtopping, bathymetric analysis, broken armor unit surveys, and photogrammetric analysis. Equipment and methodology used during data collection are presented in the following sub-sections.

\section{Prototype wave gauging}

Prototype gauges were installed at St. Paul Harbor on 27 August 1994. They consisted of two directional wave gauges (DWGs) placed outside the harbor at approximately the 12.2-m (40-ft) contour, one nondirectional pressure gauge placed along a dock inside the harbor, and one electromagnetic current meter placed inside the harbor. Locations of prototype gauges are shown in Figure 14.

The DWGs were developed at WES and included three Paros Digiquartz pressure transducers arranged in a 1.6-m (5.25-ft) equilateral triangle array. All gauge electronics and batteries were contained in a single cylinder approximately 


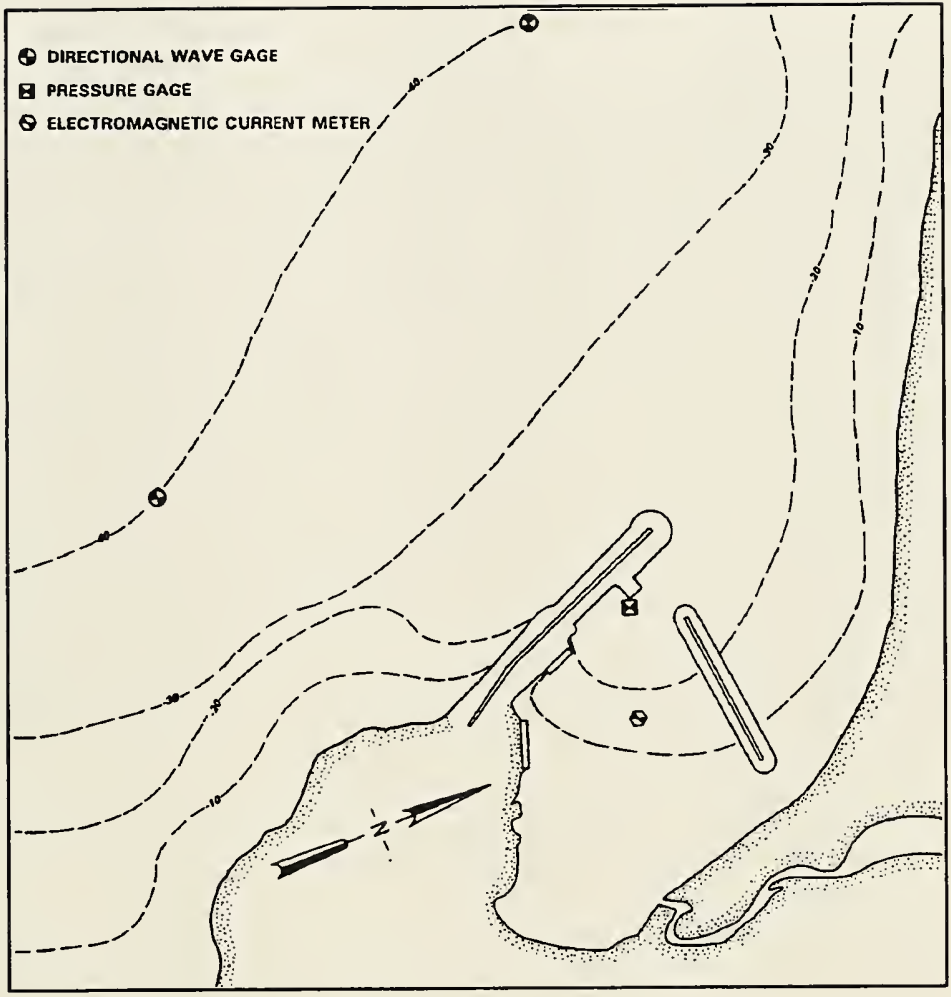

Figure 14. Prototype gauge locations at St. Paul Harbor

$1.3 \mathrm{~m}(4.25 \mathrm{ft})$ long. The compact size permitted the gauges to be deployed in small trawler-resistant pods. These pods were anchored to the sea bottom. More information on DWGs may be obtained from Howell (1993). Incident wave data as well as tide data were to be obtained from these gauges for $30 \mathrm{~min}$ every hour (on the hour). Wave data obtained from the DWGs were to be used as incident wave conditions in which correlations of wave heights and current magnitudes inside the harbor, wave runup, and wave overtopping could be made. They would begin collecting data on 15 October 1994 and extend through the winter season (through April 1995).

Sea Data 635-12 wave, tide, and current recorders were installed inside the harbor to obtain nondirectional wave data at the north dock and current data in the harbor. A Paroscientific quartz pressure sensor was installed to obtain wave data, and a Marsh-McBirney electromagnetic flow sensor was installed to collect current data. The nondirectional wave gauge was attached to a piling along the northernmost dock, and the current meter was mounted to a railroad wheel and placed in the 
harbor. These gauges would collect data for $15 \mathrm{~min}$ on 3-hr intervals and would begin obtaining data on 15 October 1994 and extend through the winter season.

In June 1995 , a recovery attempt was made for the prototype gauges. A response was received from the acoustic pinger from the southernmost DWG, but the buoy did not surface when the acoustic release was triggered. For the northernmost DWG, the acoustic pinger did not respond, nor did the buoy surface when the release was triggered. Extensive grappling for the two DWGs yielded no gauges. In addition, the nondirectional pressure gauge attached to the dock in the harbor was no longer there. The current meter in the harbor was deployed in a water depth of $4.3 \mathrm{~m}$ (14 ft); however, the depth at the site during retrieval efforts was only $0.6 \mathrm{~m}$ (2 ft). This shoaling may be related to harbor dredging that occurred in April 1995. An additional attempt to recover the DWGs occurred on 14 September 1995. WES personnel accompanied a team of National Oceanographic and Atmospheric Administration (NOAA) divers to the locations where the DWGs were deployed. These locations were determined by a hand-held global positioning system (GPS) unit. The divers deployed and searched a $30-\mathrm{m}$ (100-ft) radius in the vicinity of each gauge location but were unable to locate them. Ice conditions reported during the 1994-95 winter season by the locals were some of the worst in memory. It is possible that the wave gauges were destroyed by storm wave and/or ice conditions. Wave activity at the locations of the DWGs could also have buried the gauges in sand. The current meter in the harbor was probably buried due to the dredging that occurred in the spring of 1995.

During the period September 1994 through mid-April 1995, prototype wave data were obtained sporadically inside the harbor with pressure gauges that were mounted to the Unisea vessel, a permanently moored, floating crab processor. This vessel is moored immediately south of the northernmost dock in the harbor and is shown in Figure 3. Gauges were placed on the bottom and tied to the vessel's stern and bow. They collected data in 17.5-min bursts. Data obtained were analyzed by WES personnel and included peak wave periods and significant wave heights (average height of highest one third of the waves).

\section{Wave hindcast study}

In the absence of incident prototype wave data approaching the harbor, a wave hindcast study was performed at WES to determine hindcast wave information seaward of the St. Paul Harbor main breakwater. The Wave Information Studies (WIS) wave model was used to produce the wave information (Hubertz 1992). The hindcasting was performed in two stages: An initial stage using a relatively coarse input grid over the entire Bering Sea (Figure 15) to achieve model calibration; and a final stage using a finer resolution grid covering the St. Paul Island vicinity (Figure 16) to produce wave climatology for St. Paul Harbor.

Calibration of the wave model was achieved in the initial stage of the study by comparison of model output and measured wave data obtained from NOAA buoy 46035 , located in the central Bering Sea. Grid spacing was 0.5 deg. Global wind 


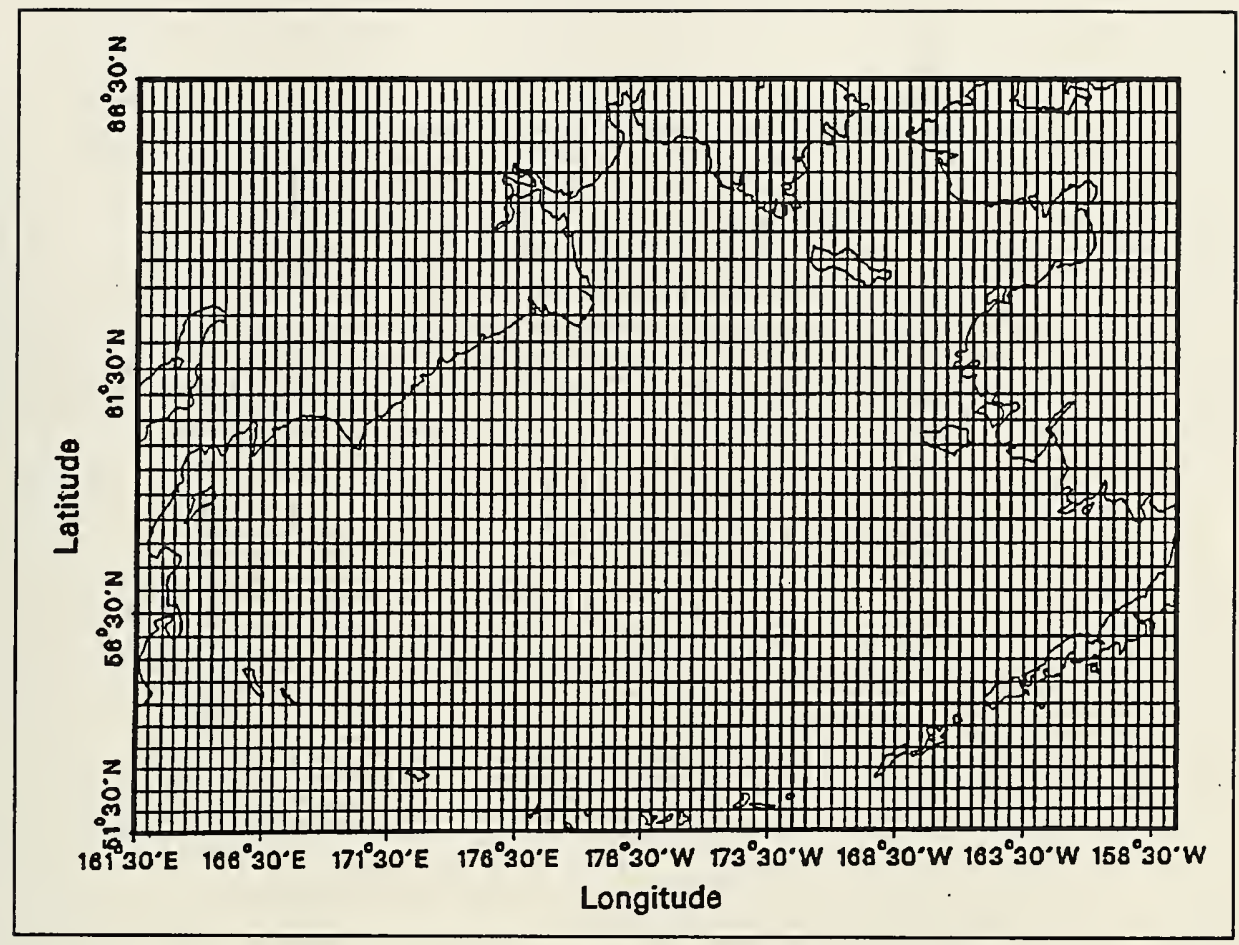

Figure 15. Coarse grid used for initial stage of wave hindcast study

data input for the model was obtained from the Mass Storage Facility and interpolated from the standard 1-deg spacing to fit the finer array of input grid points. The WIS model then was run for the months covering mid-October through midDecember 1994, using additional wind information over the month of September 1994 for model spin-up. This stage was considered a deepwater application, and no water depths were required to complete model input.

After calibration of the hindcast model for the initial stage grid, additional runs were completed to establish boundary input for the more refined final stage grid. Spacing for this grid was $1 \mathrm{~min}(0.017 \mathrm{deg})$. Global wind fields could not be interpolated with accuracy due to the fine grid spacing. This appeared not to present a problem, however, since the distance between input boundary condition points and the output location was deemed small enough to make omission of the winds acceptable. The shallow-water nature of this application made it necessary to include water depths over the entire final stage grid. Output was obtained seaward of the St. Paul Harbor main breakwater. Peak wave periods and significant wave heights were obtained covering the period mid-October 1994 through midDecember 1994. 


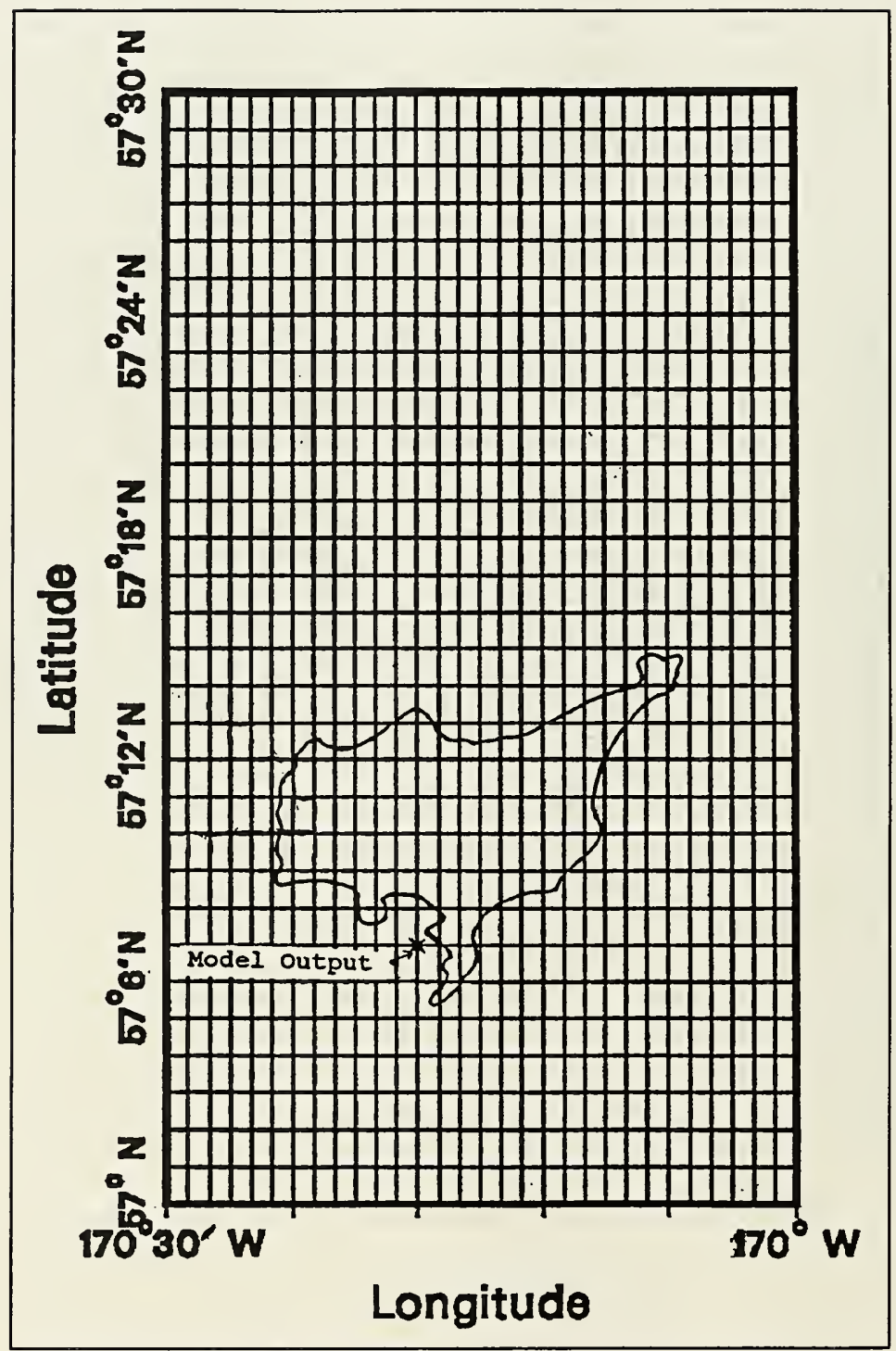

Figure 16. Fine-resolution grid used for final stage of wave hindcast study 


\section{Wave runup}

Wave runup on the face of the St. Paul Harbor main breakwater was obtained with a videotape system. This technique has been used previously to measure runup on beach slopes, but was modified to secure breakwater runup for St. Paul. A video camera was set up and mounted on the cliff south of, and overlooking, the harbor (Figure 17). Four ground control points (GCP) along the breakwater crest and two profile locations (PFL) along the breakwater face were established as shown in Figure 18. The $\mathrm{x}, \mathrm{y}$, and $\mathrm{z}$ coordinates of the camera location, the center of the GCPs, and points along the PFLs then were determined to establish the required geometry. By using the GCPs as control and knowing the profile, a time series of wave runup was generated. The surface of the water on the structure was digitized six times per second along the breakwater PFLs. Digitization was completed from videotape. The data can be retrieved, displayed on a monitor, and analyzed for runup time series. This technique has the advantages of being low-cost, logistically simple, and providing relatively accurate measurements. More information on obtaining wave runup through videotaping techniques may be found in Hathaway, Howd, and Oltman-Shay (in publication).

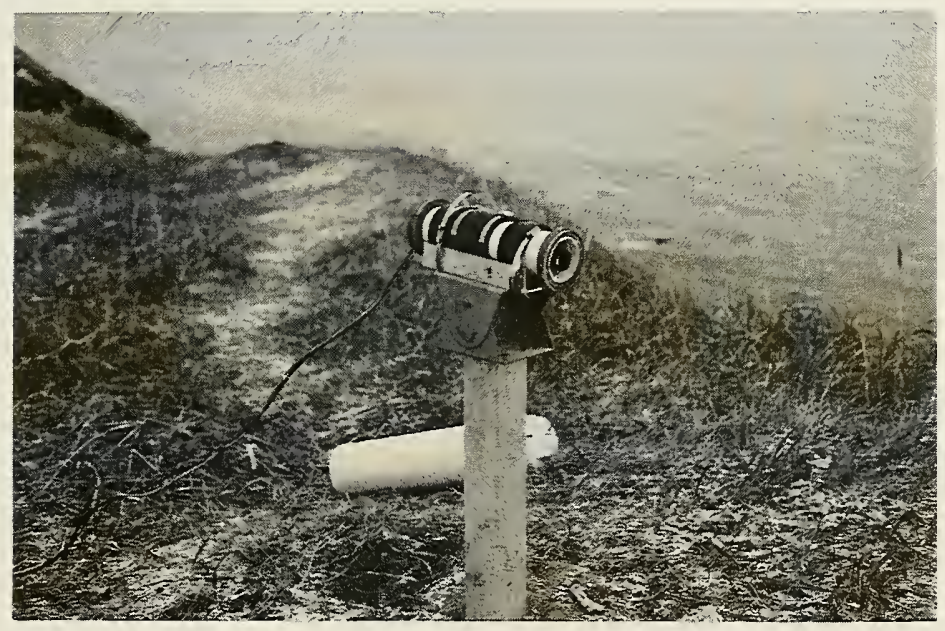

Figure 17. Video camera used to obtain runup data

WES personnel were onsite and obtained videotape footage during the midOctober through mid-December 1994 time period. The camera was mounted and connected to a recorder, and videotape footage was generally obtained twice daily for 30-min durations. A log book was maintained during periods when the data were collected. The videotapes were analyzed to secure wave runup time series and subsequent vertical runup data. Data were initially generated for both PFLs, but since they were in close agreement, only PFL 1 (the most shoreward profile) was analyzed to decrease analysis time. Runup values reported are significant values 


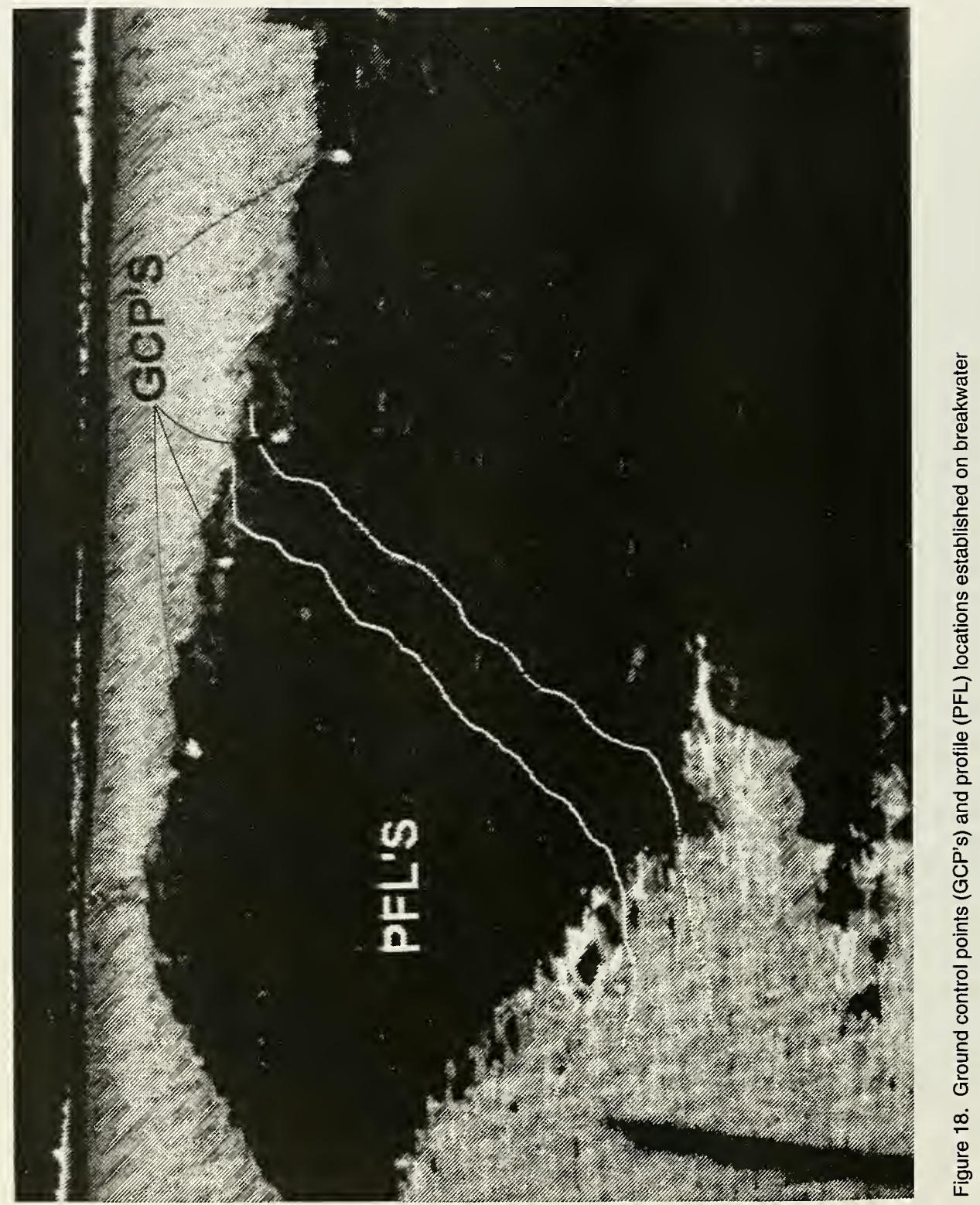


(average of highest one third of the runup values). Wave runup periods also were obtained from the time series.

\section{Wave overtopping}

To measure and quantify wave overtopping at the St. Paul Harbor main breakwater during storm wave events, a water collection container placed in the lee of the structure and flow meters were used. An open top container, approximately $12.2 \mathrm{~m}$ x $3 \mathrm{~m} \mathrm{x} 2.4 \mathrm{~m}$ ( $40 \mathrm{ft} \times 10 \mathrm{ft} \times 8 \mathrm{ft}$ ), was modified to serve as a collection box for waves overtopping the breakwater. The container was lined with metal to prevent leakage and included $20.3-\mathrm{cm}$ (8-in.) pipes, extending from its base, in which flow meters were installed to determine flow rates.

During the period 25 through 30 August 1994, a crew of WES personnel visited St. Paul Island to prepare a concrete slab to be used as a base for the container, to install the container, and to construct an apron from the top of the container up the breakwater slope. Heavy equipment was rented from the City of St. Paul. A 20.3-cm (8-in.) reinforced concrete slab was initially constructed in the lee of the breakwater (sta $8+20-8+60$ ). The open top container then was placed on the slab and anchored into position with chains. An apron extending from the top of the container up the slope of the breakwater then was constructed to direct overtopping volumes into the container. The apron consisted of $10.2 \mathrm{~cm} \mathrm{x} 10.2 \mathrm{~cm}(4 \mathrm{in}$. $\mathrm{x} 4 \mathrm{in}$.) wooden frames and bracing with a metal skin attached to the framing. A view of the completed container setup is shown in Figure 19.

To measure overtopping rates, ultrasonic flow transducers were mounted to the 3.1-cm (8-in.) pipe at the base of the container and connected to a recorder (Figure 20). By knowing the water level in the container at the beginning and end of a

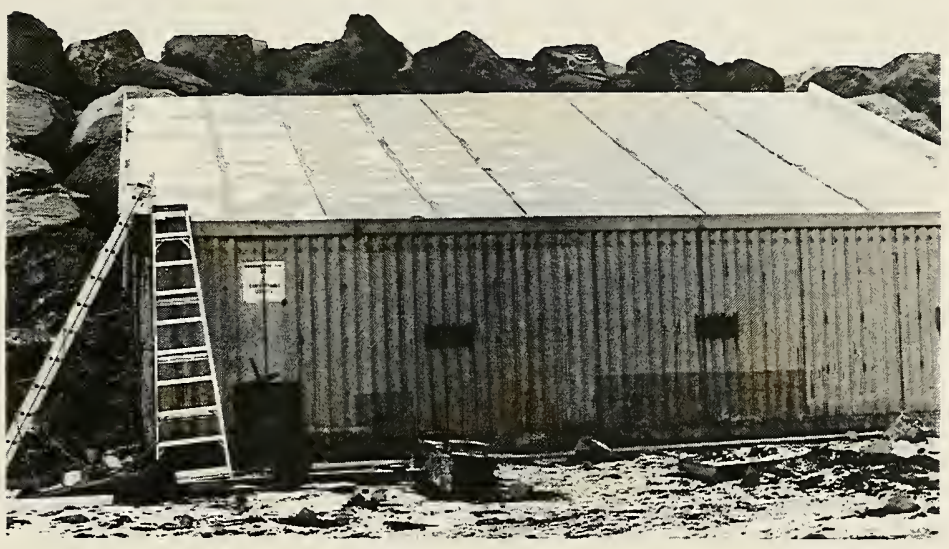

Figure 19. View of collection box used for measurement of wave overtopping 


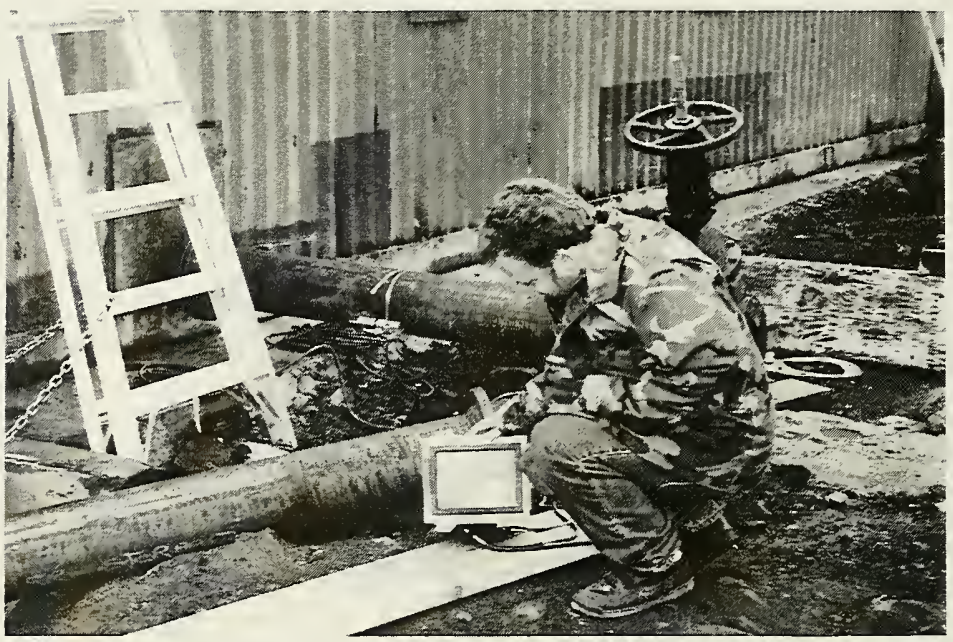

Figure 20. Flow transducers and recorder used to determine overtopping rates

test series, and the volume of water flowing through the outlet pipe over a certain time period, the overtopping rates may be calculated.

The first storm of the 1994-95 winter season that produced overtopping of the main breakwater occurred on 3 November 1994. WES personnel were onsite to measure these rates. Data were collected from 10:00 a.m. to 1:00 p.m. Massive overtopping of the structure occurred (Figure 21), and it is estimated that approximately 50 percent of the overtopping waves were not collected due to spray and waves "overshooting" the container. During the storm the apron extending from the top of the container up the slope of the breakwater collapsed, as shown in Figure 22. Before the storm system subsided, the forces of the overtopping waves caused the anchors to pull out of the concrete slab. The container tilted forward (shoreward), bending the pipes used to measure the flow rates. Due to logistical problems, it was not feasible to repair the container. Therefore, data obtained initially on 3 November 1994 were the extent of the wave overtopping obtained during the monitoring effort.

\section{Bathymetry}

Bathymetric data in and adjacent to St. Paul Harbor had been obtained in September 1986 (prior to construction of breakwater improvements) and again in August 1992 (after breakwater construction). These pre- and post-construction data were analyzed to determine the impact of the improvements on bathymetric conditions in and adjacent to the harbor. An additional bathymetric survey was completed in July 1995 as part of the monitoring program. This survey was analyzed 


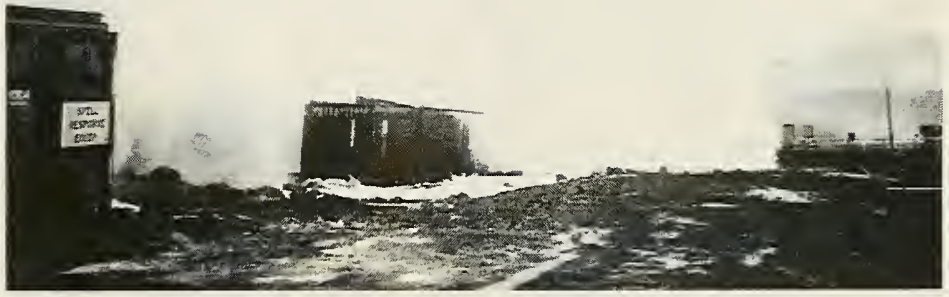

Figure 21. Massive overtopping of St. Paul Harbor main breakwater on 3 November 1994

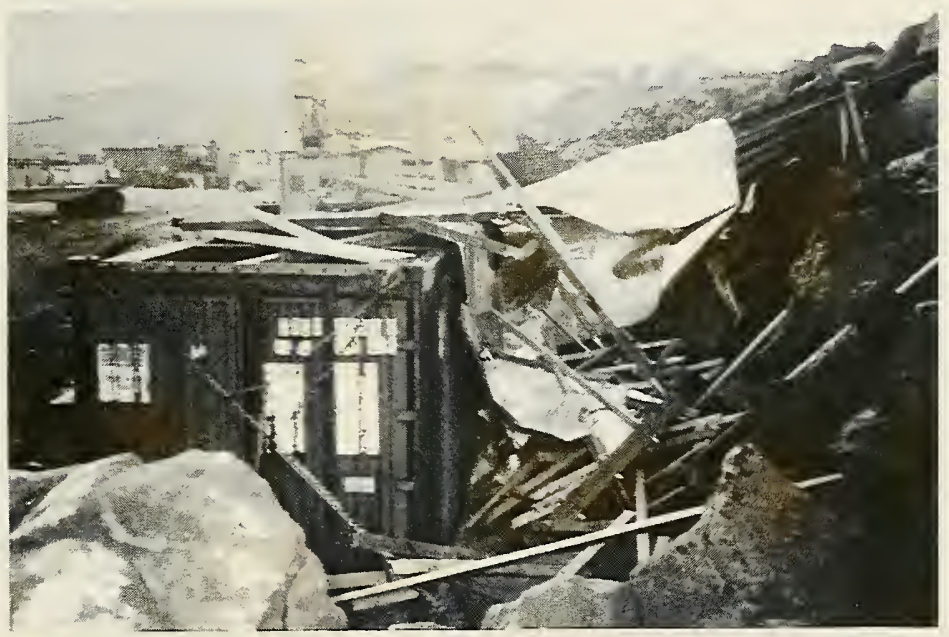

Figure 22. Collapsed apron resulting from 3 November 1994 storm 
to determine if bathymetric conditions had stabilized as a result of breakwater construction.

\section{Broken armor unit surveys}

A survey of broken/cracked armor stone above the waterline on the $320-\mathrm{m}$-long (1,050-ft-long) St. Paul Harbor outer main breakwater was conducted four times during the monitoring period. Surveys were conducted in July 1993, June 1994, June 1995, and June 1996. During the inspections, each broken armor stone was identified and photographed, and its approximate location relative to breakwater station and distance from a baseline was recorded. The baseline was the approximate centerline of the structure. Armor stones with hairline cracks were not counted; only those that were cracked all the way through. A geological assessment of the broken stone was conducted during the June 1995 survey.

\section{Photogrammetric surveys}

Photogrammetric surveys, as well as ground surveys for control, were conducted during May 1994 and May 1996. To establish control for the photogrammetric work, monuments were established on the breakwater. Ground surveys were initiated from existing known monuments, which included National Geodetic Survey stations and a Corps of Engineers station. They were established by GPS control and electronic land surveying techniques. In addition, targets were established at intervals of about $55 \mathrm{~m}(180 \mathrm{ft})$ along the sea side, harbor side, and approximate center of the breakwater. Each target was marked with a drill hole $0.64 \mathrm{~cm}(1 / 4 \mathrm{in}$.) in diameter, and $0.64 \mathrm{~cm}$ (1/4 in.) deep, and painted with a circular target to ensure visibility in aerial photography. A typical target is shown in Figure 23. Targets were electronically surveyed to form control by which the accuracy of the photogrammetric survey work could be validated. Horizontal positions were based on the Alaska State Plane Coordinate System and elevations were referenced to mean lower low water datum.

Aerial photography is a very effective means of capturing images of large areas for later analysis, study, visual comparison to previous or subsequent photography, or measurement and mapping. Its chief attribute is the ability to freeze a moment in time, while capturing extensive detail. Low-altitude aerial photography was obtained along the breakwater with a Wild RC-8 aerial mapping camera (22.9-cm by $22.9-\mathrm{cm}$ ( 9 -in. by 9 -in.) format). The photos were secured from a helicopter flying at an altitude of $91 \mathrm{~m}(300 \mathrm{ft})$, which resulted in high-resolution images and contact prints with scales of 1:600. Photographic stereo pairs were obtained during the flights.

When aerial photography is planned and conducted so that each photo image overlaps the next by 60 percent or more, the two photographs comprising the overlap area can be positioned under an instrument called a stereoscope and viewed in extremely sharp three-dimensional detail. If properly selected survey points on 


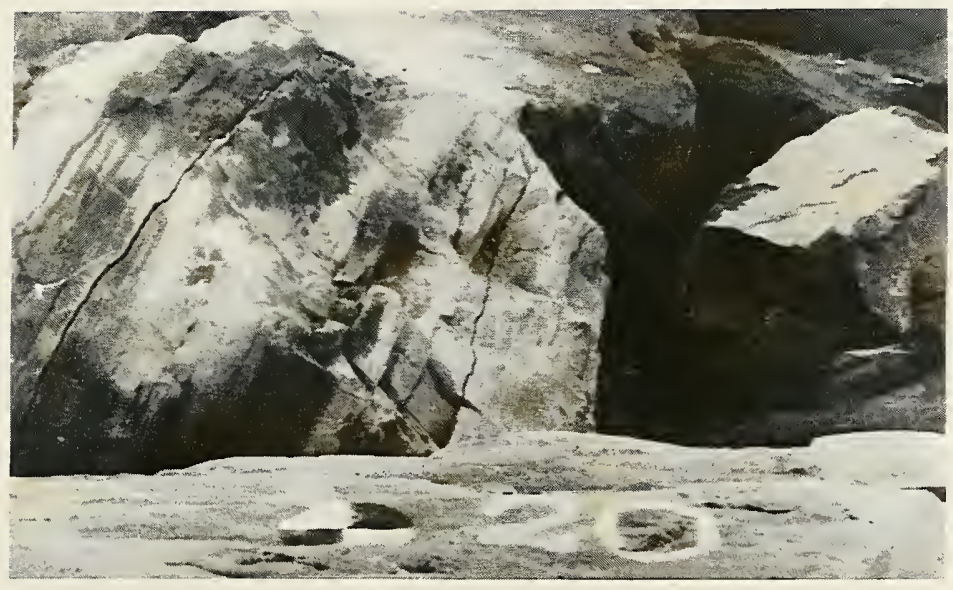

Figure 23. Example of target established on St. Paul breakwater

the ground have previously been targeted and are visible in the overlapping photography, very accurate measurements of any point appearing in the photographs can be obtained. This technique is called photogrammetry. The low-altitude stereo pair images obtained during aerial photography at St. Paul Harbor were viewed in a stereoscope and stereomodels were oriented to the monument and target data previously obtained. In the stereomodel, very accurate horizontal and vertical measurements can be made of any point on any armor stone appearing in the print. The stereomodel was used for all photogrammetric compilation and development of orthophotography.

Orthophotos combine the image characteristics of a photograph with the geometric qualities of a map. The digital orthophoto is created by scanning an aerial photograph with a precision imaging scanner. The scanned data file is digitally rectified to an orthographic projection by processing each image pixel. Orthophotos were prepared for the St. Paul Harbor main breakwater. Precise horizontal measurements may be obtained from the orthophotos using an engineer scale since the image has been rectified and is free from skewness and distortion.

In addition to digital orthophotos, point plot maps, contour maps, and cross sections were developed for the main breakwater using the digital terrain model (DTM). Point plot maps consisted of an approximately $0.5-\mathrm{m}(1.5-\mathrm{ft})$ grid pattern overlaid on the structure. Precise vertical and horizontal measurements were obtained at the intersections of the grid. Contour maps of the breakwater, developed from the DTM, for a $0.3-\mathrm{m}(1-\mathrm{ft})$ contour interval also were obtained. In addition, using the analytical stereoplotter and DTM grid, cross sections were developed along the breakwater at $30.5-\mathrm{m}(100-\mathrm{ft})$ intervals. 


\section{Data Results and Discussion}

The loss of the two DWGs placed outside the harbor significantly reduced the value of some of the other data obtained during the monitoring effort. The DWGs were deployed to obtain incident wave data that were required for correlation with wave heights inside the harbor, wave runup, and wave overtopping data. Since incident wave data were not obtained, these elements of the monitoring effort could not be validated or verified based on the physical modeling and/or numerical tools used in their predictions.

When working in an environment with a high-energy wave climate like St. Paul Harbor, extra precautions should be taken to ensure that data are collected. More appropriate anchoring of the gauge mounts and/or devices hard-wired to shore to obtain real-time data should be considered. Additional costs will be required, of course, and should be included when estimates for the monitoring program are prepared. In addition, when working at a remote site such as St. Paul Harbor, logistical problems are a factor. Equipment and supplies must be shipped and, in most cases, delivery times are uncertain. Shipping costs also are significantly higher when working in a remote environment, and equipment and materials are not readily available.

Wave height data obtained inside the harbor in the lee of the main breakwater are presented in Table 2. Gauge No. 276 was closest to the harbor entrance tied to the Unisea's bow, and gauge No. 277 was tied to the vessel's stern. Maximum significant wave heights obtained during the period of record were $0.58 \mathrm{~m}(1.9 \mathrm{ft})$. Even though a correlation cannot be made with incident incoming wave characteristics, it is known that storms occurred during the monitoring period. In the threedimensional model investigation of St. Paul Harbor, a range of extreme storm wave conditions were tested from several directions with maximum significant wave heights of $0.79 \mathrm{~m}(2.6 \mathrm{ft})$ predicted in the lee of the breakwater. Direct correlations cannot be made for specific incident waves; however, it appears the prototype and model data are in agreement. Model wave heights are slightly higher than those in the prototype, but the prototype may not have experienced an extreme storm from as critical a direction as the events tested in the model.

Results of the wave hindcast model are presented in Table 3 for the dates and times indicated. Output was generated to correlate with the dates and times that wave runup and overtopping were obtained. Wave hindcast results revealed maximum significant incident wave heights of $5 \mathrm{~m}(16.4 \mathrm{ft})$. Data indicated that storms with wave heights in excess of $3 \mathrm{~m}$ (10 ft) occurred on 11-12 November, 14-15 November, 25-26 November, and 10 December 1994. Initial results revealed that trends were established in that larger waves generally occurred with higher wave runup values and smaller waves occurred with lower runup. The absolute values of the wave heights, however, appeared low. These values will be discussed in more detail after presentation of wave runup and overtopping results.

Wave runup data secured for the St. Paul Harbor main breakwater, using the videotape methodology developed, are presented in Table 4 for the times and dates 
indicated. Wave runup values in excess of $6.1 \mathrm{~m}(20 \mathrm{ft})$ occurred on 15 occasions (19 and 22 October; 1, 2, 9, 10, 12, 14, 15, 16, 23 and 26 November; and 10, 11 and 12 December 1994) during the monitoring period. Overtopping of the structure also was observed on four occasions (3,11, 14, and 25 November 1994). Analysis of wave runup on the structure using the videotape methodology proved to be successful except during periods when visibility was low. Since incident wave data were not obtained, it was not possible to correlate runup results with those obtained in the two-dimensional model and/or those predicted by the Shore Protection Manual.

Wave overtopping rates of $1.7 \mathrm{l} / \mathrm{sec} / \mathrm{m}(0.022 \mathrm{cfs} / \mathrm{ft})$ were calculated from the container in the lee of the main breakwater during the 3-hr period prior to the collapse of the container apron on 3 November 1994. As mentioned previously, as much as 50 percent of the overtopping waves were not collected due to spray and "overshooting" of the container during the storm. Therefore, the actual rates are not quantifiable. It was also noted that significant volumes of water were reaching the road as a result of waves passing through the rubble-mound structure. These values could not be quantified with the equipment setup that was onsite. Waves passing through the structure and overtopping from this storm were obviously unacceptable since they resulted in washing out of the road in the lee of the breakwater. Since incident wave conditions were not known and overtopping rates could not be quantified for this storm event, no attempt was made to correlate overtopping results with the two-dimensional model study results or guidance provided in the Shore Protection Manual.

Logistical problems were experienced in the delivery of the container and materials for its apron to St. Paul Island. The container was modified, and materials for the apron were prefabricated, on the west coast of the U.S. mainland, since this work could not be done at the remote Alaskan location. These items were shipped to St. Paul Island by barge. Delivery dates to St. Paul were uncertain; however, coordination with the harbormaster resulted in the equipment being off-loaded at the harbor. Originally, plans were to design and construct the apron with a Z-beam steel frame and corrugated metal skin. Welders would have been required to assemble the apron. Since they were not available for hire at St. Paul, the decision was made to prefabricate the wooden frame and assemble it onsite. The apron was not expected to endure the entire storm season, but it was expected that data could be obtained for less severe storms. As stated earlier, it was destroyed during the first major storm of the season. These factors should be considered in future monitoring efforts in remote, high-wave-energy locations.

Measured wave runup data and observed wave overtopping were correlated with wave hindcast data. On the dates and times when runup values exceeded $6.1 \mathrm{~m}$ $(20 \mathrm{ft}$ ), incident wave height data predicted by the hindcast model ranged from 0.5 to $4.8 \mathrm{~m}$ ( 1.6 to $15.7 \mathrm{ft}$ ). During periods of observed overtopping, hindcast wave height predictions ranged from 2.3 to $5 \mathrm{~m}$ ( 7.6 to $16.4 \mathrm{ft}$ ). Wave periods obtained from the hindcast model ranged from 6 to $15 \mathrm{sec}$, and those measured from videotape ranged from 9.7 to $19.7 \mathrm{sec}$. A specific case compared was conditions on 3 November 1994, when the overtopping container apron was destroyed. Hindcast data indicated a wave height of $2.6 \mathrm{~m}(8.5 \mathrm{ft})$. Preliminary wave runup calculations 
for 2.6- $\mathrm{m}(8.5-\mathrm{ft})$ waves indicate a runup value between 4.9 and $5.2 \mathrm{~m}$ (16 and $17 \mathrm{ft}$ ) would occur (based on Shore Protection Manual predictions); however, massive overtopping actually occurred that resulted in destruction of the apron. Local forecasts indicated winds of 50 knots and seas of $9.1 \mathrm{~m}(30 \mathrm{ft})$ on 3 November 1994. Based on these comparisons, the hindcast data appear to have under-estimated wave conditions at the site. As stated earlier, in general, trends indicated larger waves occurred with higher runup values and wave overtopping, but absolute values of the wave heights generated by the hindcast model appeared low.

Bathymetric data obtained in and adjacent to the harbor in September 1986 (prior to construction of breakwater improvements) are shown in Figure 24. Note the 10.4-m (34-ft) el scour hole adjacent to the head of the breakwater. The scour hole formed after construction of the original 229-m-long (750-ft-long) breakwater in 1985. It was monitored by CENPA and did not tend to undermine the breakwater foundation. Depths adjacent to the vertical-walled, concrete caisson City Dock were dredged to greater than $6.1 \mathrm{~m}(20 \mathrm{ft})$. Though not shown in the bathymetry, CENPA noted that the cove appeared to begin filling in after initial breakwater construction with accretion along the southeast shoreline of Village Cove. At one point the connecting channel between the cove and saltwater lagoon was plugged and subsequently artificially reopened.

Bathymetric data obtained in August 1992 (after breakwater improvements) are shown in Figure 25. A 10.4-m (34-ft) scour hole formed adjacent to the head of the new main breakwater extension similar to the one formed after the original breakwater was constructed. The scour hole did not appear to have significantly undermined or impacted the stability of the structure head. Depths in the harbor between the northernmost dock and City Dock were greater than the $5.5-\mathrm{m}(18-\mathrm{ft})$ authorized federal channel and maneuvering area, and therefore, dredging was not required after construction. Local interests did, however, dredge an area in the harbor adjacent to the TDX dock. Note the change in contours north of and adjacent to the detached breakwater. Sediment began accumulating against the structure.

Contours of bathymetric changes that occurred between the September 1986 and the August 1992 surveys are shown in Figure 26. These contours show fill and scour conditions in and adjacent to the harbor. The figure shows a $3.7-\mathrm{m}(12-\mathrm{ft})$ scour hole had formed adjacent to the head of the outer breakwater. In addition, accretion up to $4.3 \mathrm{~m}$ (14 ft) had occurred adjacent to the north side of the detached breakwater. An underwater spit had formed north of the west end of the detached structure and has the potential to migrate across the channel. Accretion of $3 \mathrm{~m}$ (10 ft) occurred adjacent to the south side of the detached breakwater which suggested sediment may be moving through the structure. Inside the harbor, the scour north of the TDX dock was due to dredging by local interests. Also, the scour hole formed by the original 229 -m-long (750-ft-long) outer breakwater appeared to be filling. This may be due to settlement of suspended sediment caused by vessel prop wash, dredging operations, and/or hydrodynamic conditions. The August 1992 survey did not include bathymetry in the area in the lee of the east end of the detached breakwater and adjacent to the shoreline inside the harbor. 


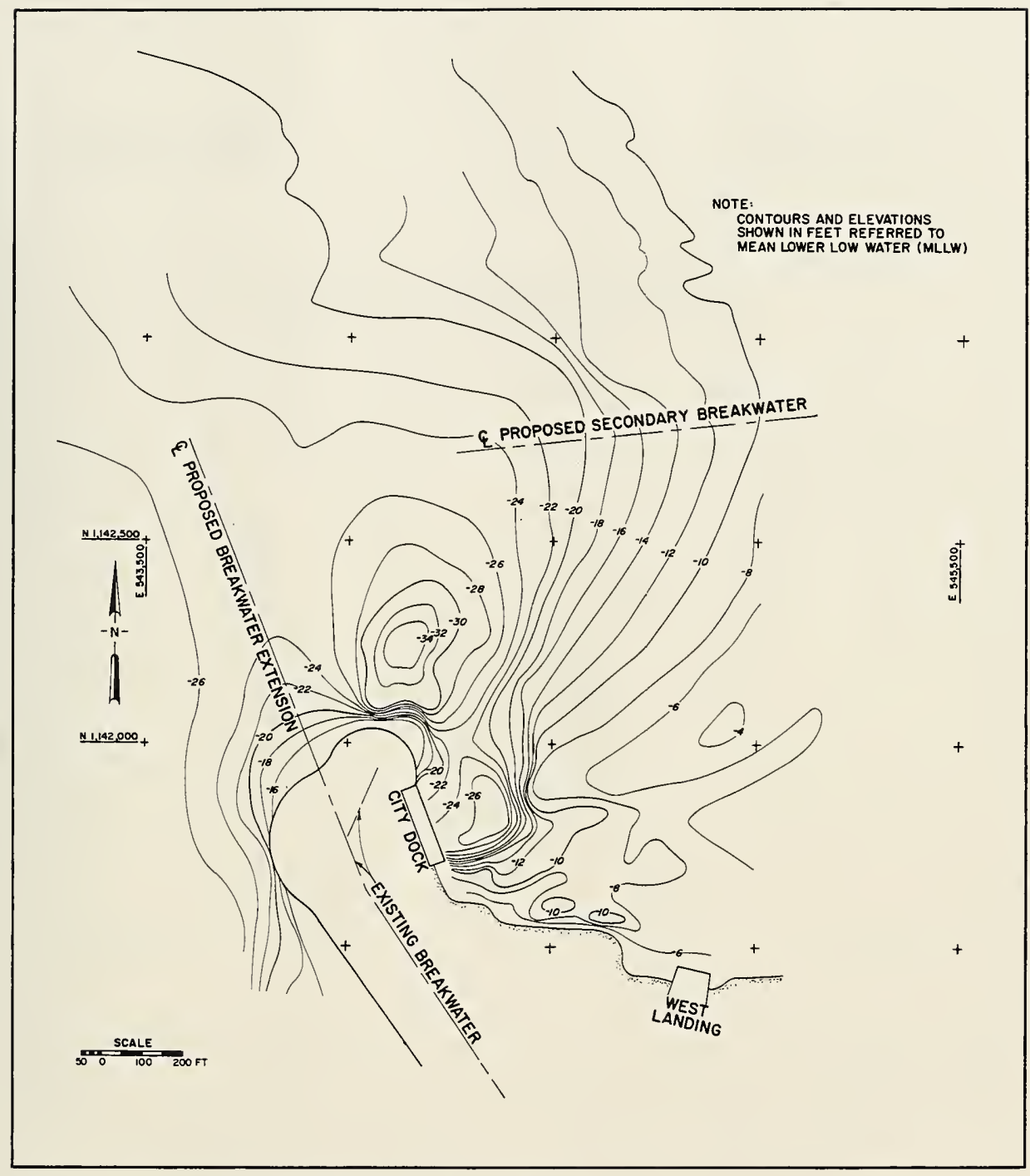

Figure 24. Bathymetry at St. Paul Harbor, September 1986 


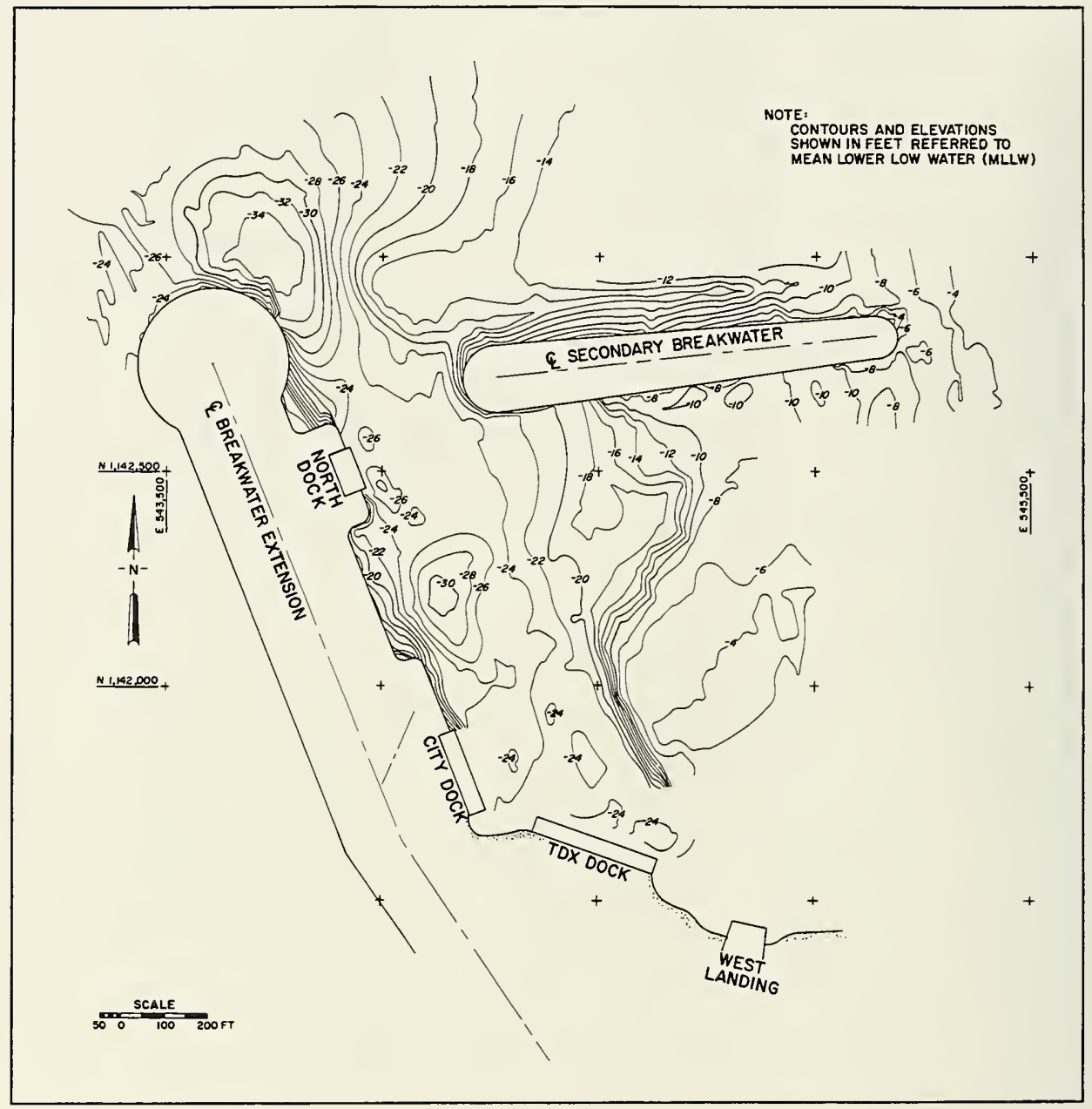

Figure 25. Bathymetry at St. Paul Harbor, August 1992

Bathymetric data obtained during the July 1995 survey are shown in Figure 27. The scour hole that had formed at the head of the structure in the August 1992 survey appears to have slightly filled in and shifted slightly west around the head of the structure. To this point, the scour hole has not impacted the stability of the head of the breakwater. The contours north of and adjacent to the detached breakwater are similar to the 1992 survey. To this point, the underwater spit has not had any negative impact on navigation. Local interests dredged an area inside the harbor 


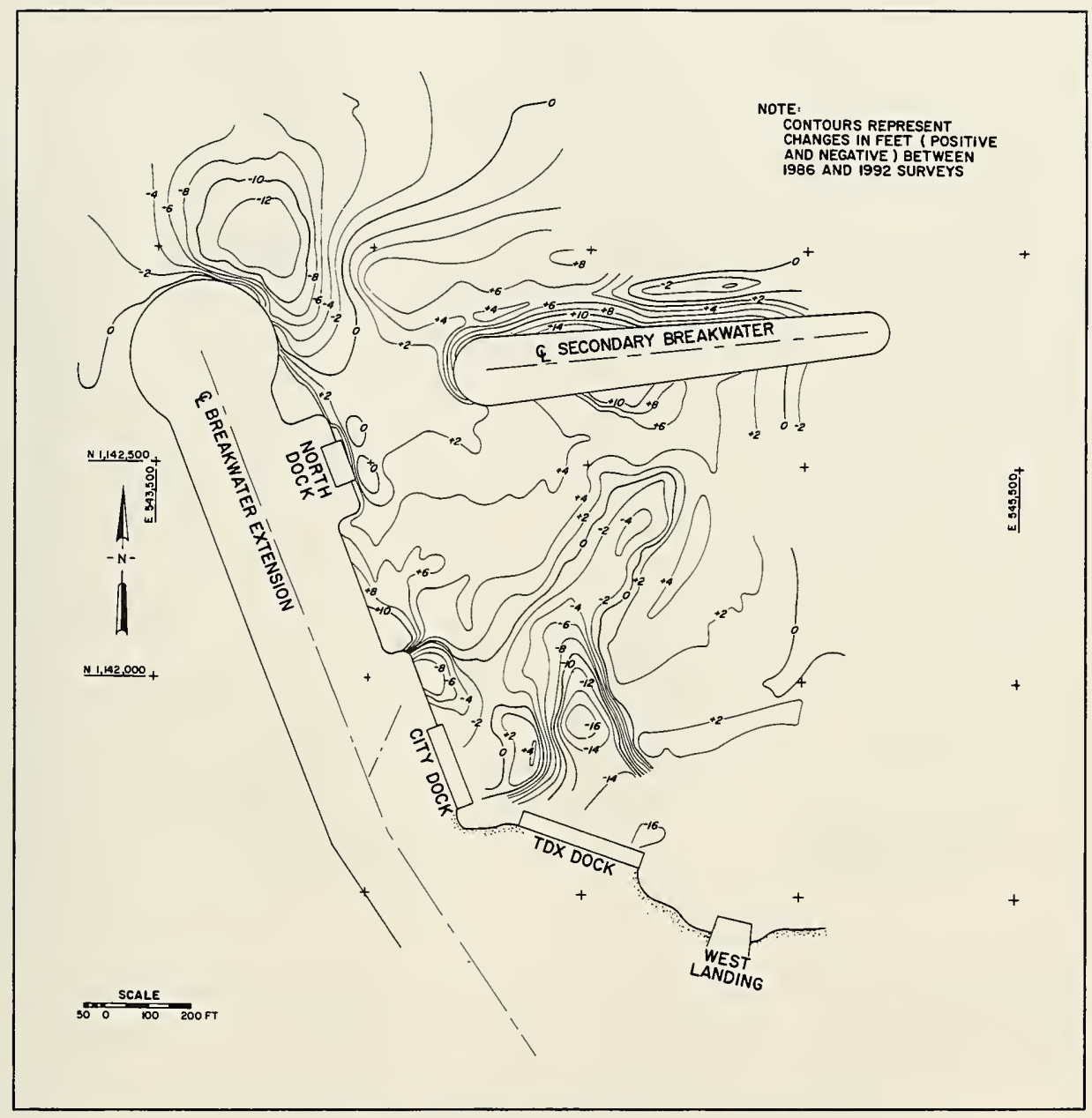

Figure 26. Contours of bathymetric changes between September 1986 and August 1992 surveys

north of the West Landing. The 1995 survey extended further north of the detached breakwater and included more data inside the harbor than the previous survey.

Contours of bathymetric changes that occurred between the August 1992 and July 1995 surveys are shown in Figure 28. The figure shows that the old (1992) scour hole location has filled in about $1.8 \mathrm{~m}(6 \mathrm{ft})$, with a $1.8-\mathrm{m}(6-\mathrm{ft})$ cut at the new location to the west. The accretion immediately adjacent to the north side of the detached breakwater in 1992 had subsided by $3 \mathrm{~m}$ (10 ft). Not shown on the figure (due to lack of data in 1992), however, is a slight shift in the underwater spit north 


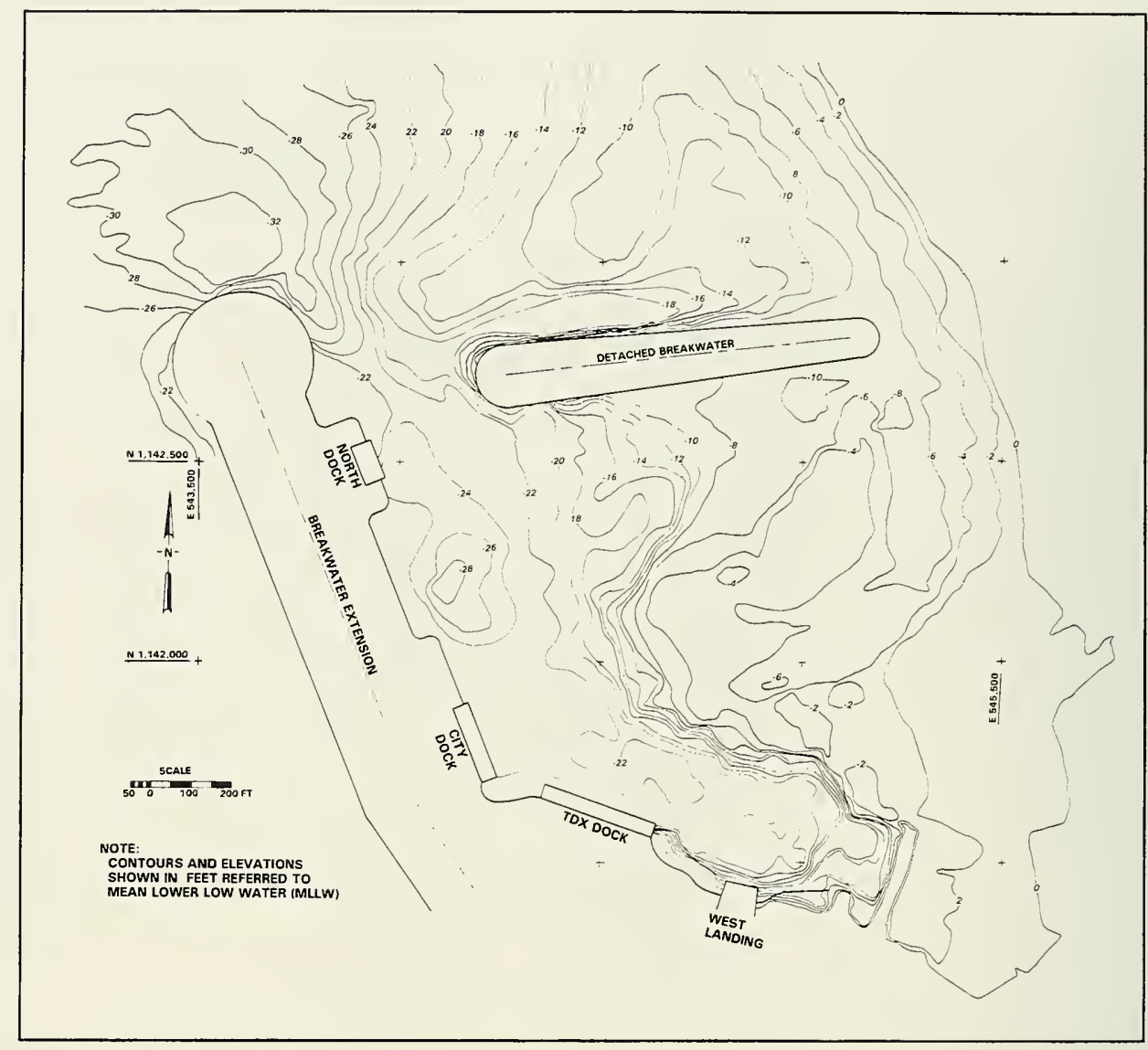

Figure 27. Bathymetry at St. Paul Harbor, July 1995

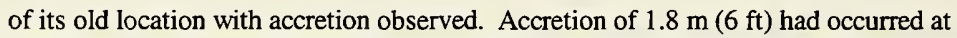
the seaward head of the detached breakwater. Cut and fill inside the harbor north of the TDX dock was probably related to the dredging operations at West Landing by local interests.

In an effort to better quantify scour and fill conditions at the harbor entrance, two areas were selected for more detailed analysis. Figure 29 presents the areas identified. Area A consists of $15,500 \mathrm{sq} \mathrm{m}(166,800 \mathrm{sq} \mathrm{ft})$ and was initially used to determine scour adjacent to the head of the breakwater extension; Area B includes $11,770 \mathrm{sq} \mathrm{m}(125,700 \mathrm{sq} \mathrm{ft})$ and was used to depict accretion across a portion of the entrance. Detailed bathymetry (0.3-m (1- ft) intervals) for Areas A and B are shown in Figures 30 through 32 for the 1986, 1992, and 1995 surveys, respectively; and 


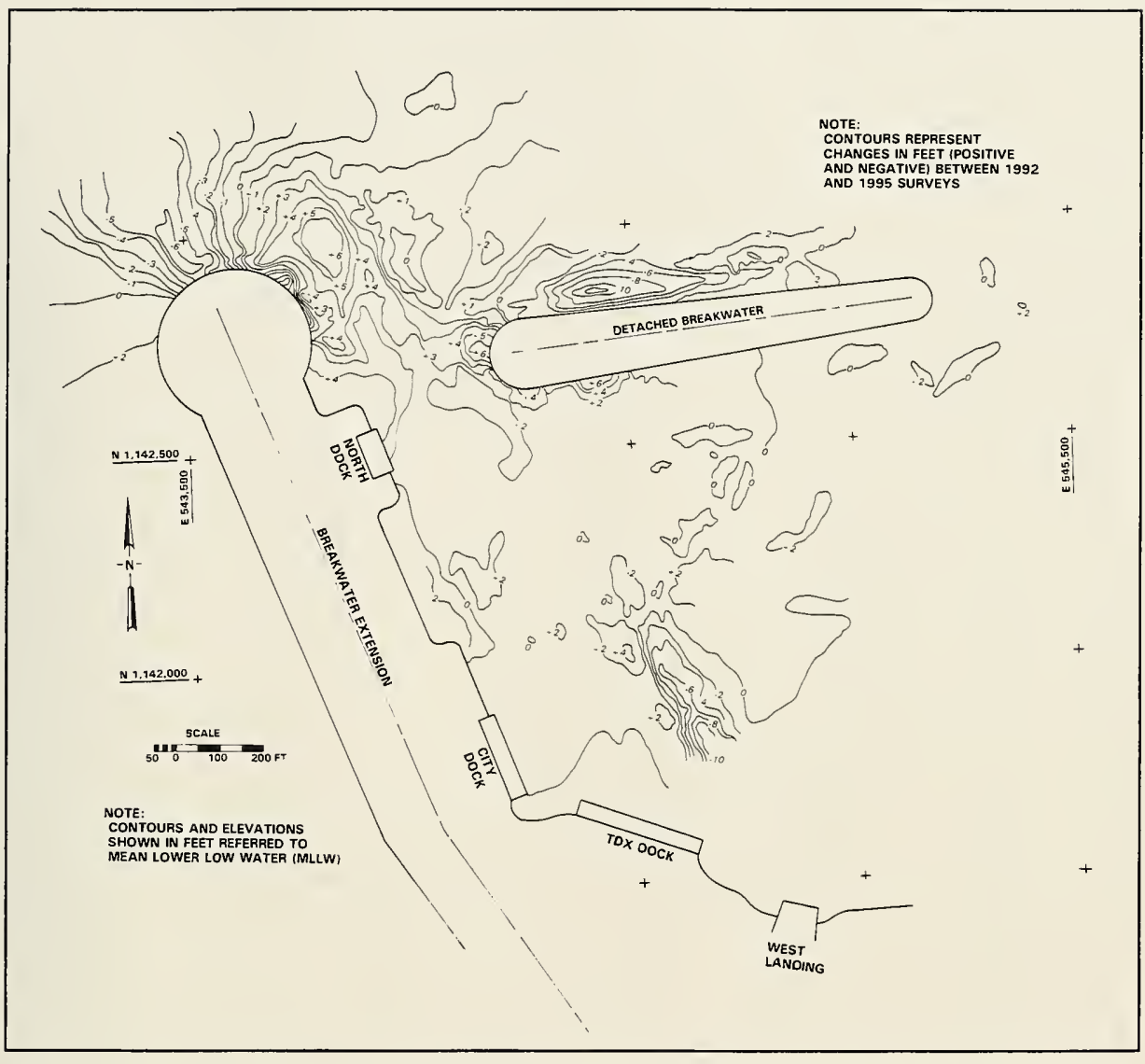

Figure 28. Contours of bathymetric changes between August 1992 and July 1995 surveys

cross sections through Areas A and B (at locations shown in Figure 29) are presented in Figures 33 through 35 for the various surveys. Contours of bathymetric changes that occurred between September 1986 and August 1992 are shown in Figure 36, and those occurring between August 1992 and July 1995 are presented in Figure 37. Erosion and accretion volumes were calculated for each area. Results indicate that, during the period 1986 through 1992, approximately $31,960 \mathrm{cu} \mathrm{m}$ (41,800 cu yd) of scour occurred in Area A and about $13,070 \mathrm{cu} \mathrm{m}(17,100 \mathrm{cu}$ yd) of accretion occurred in Area B. This was the result of post-breakwater modifications. Between 1992 and 1995, Area A accreted about 4,660 cu m (6,100 cu yd) and Area B accreted approximately $5,350 \mathrm{cu} \mathrm{m}(7,000 \mathrm{cu}$ yd) of material. Net volumes (between 1986 and 1992) are 27,300 cu m (35,700 cu yd) of scour in Area A and $18,420 \mathrm{cu} \mathrm{m}(24,100 \mathrm{cu}$ yd) of fill in Area B. 


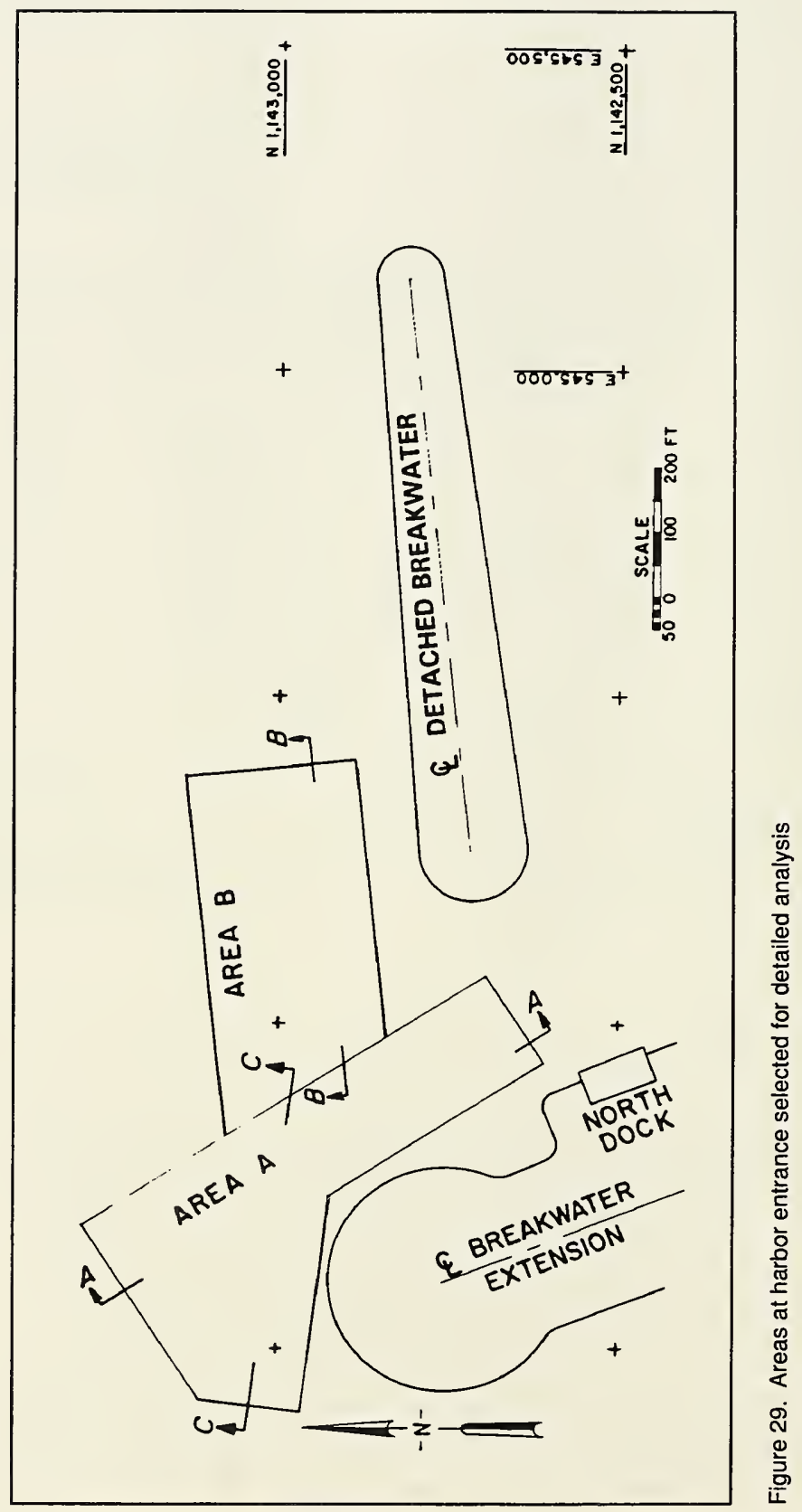




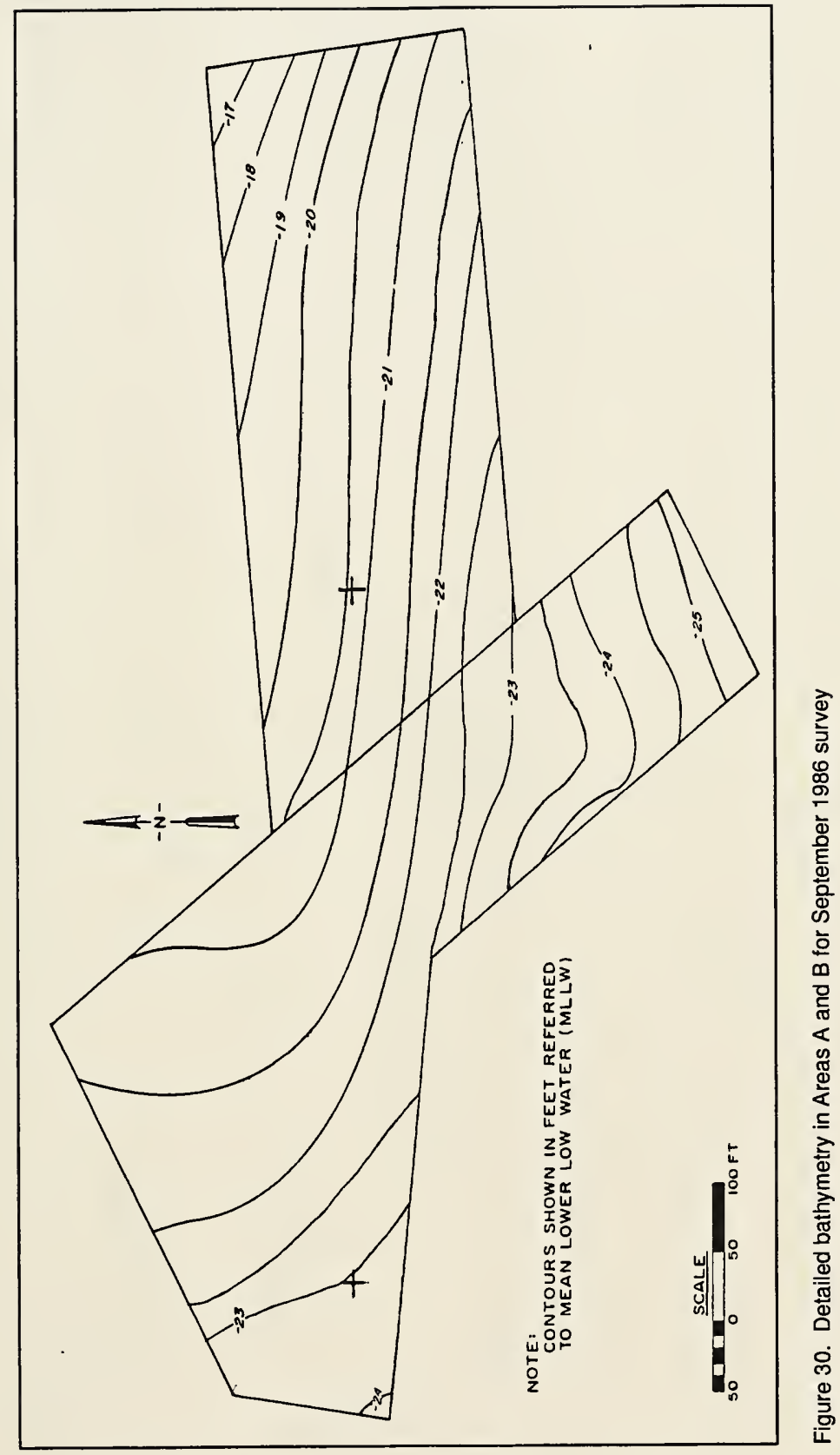




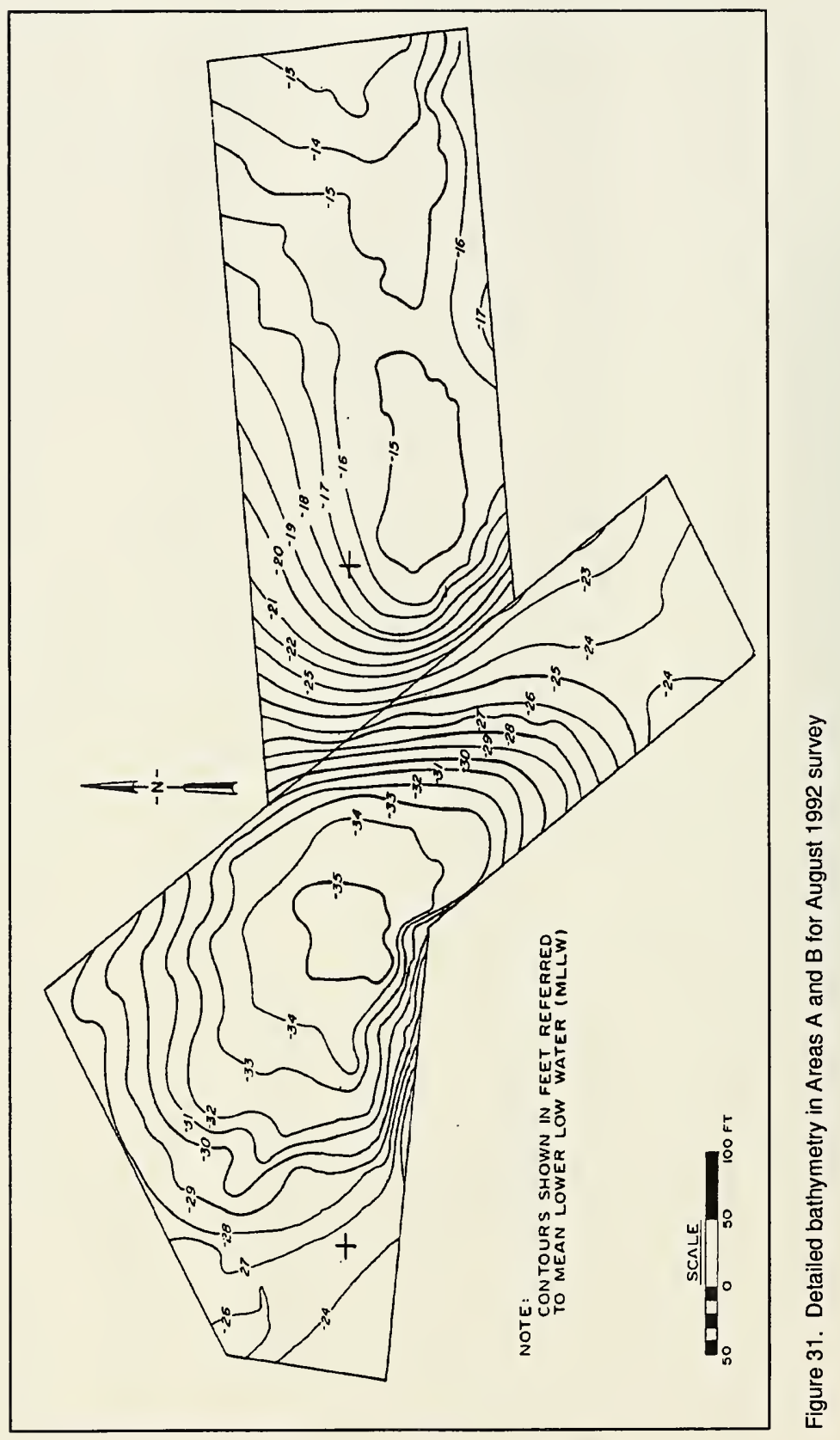




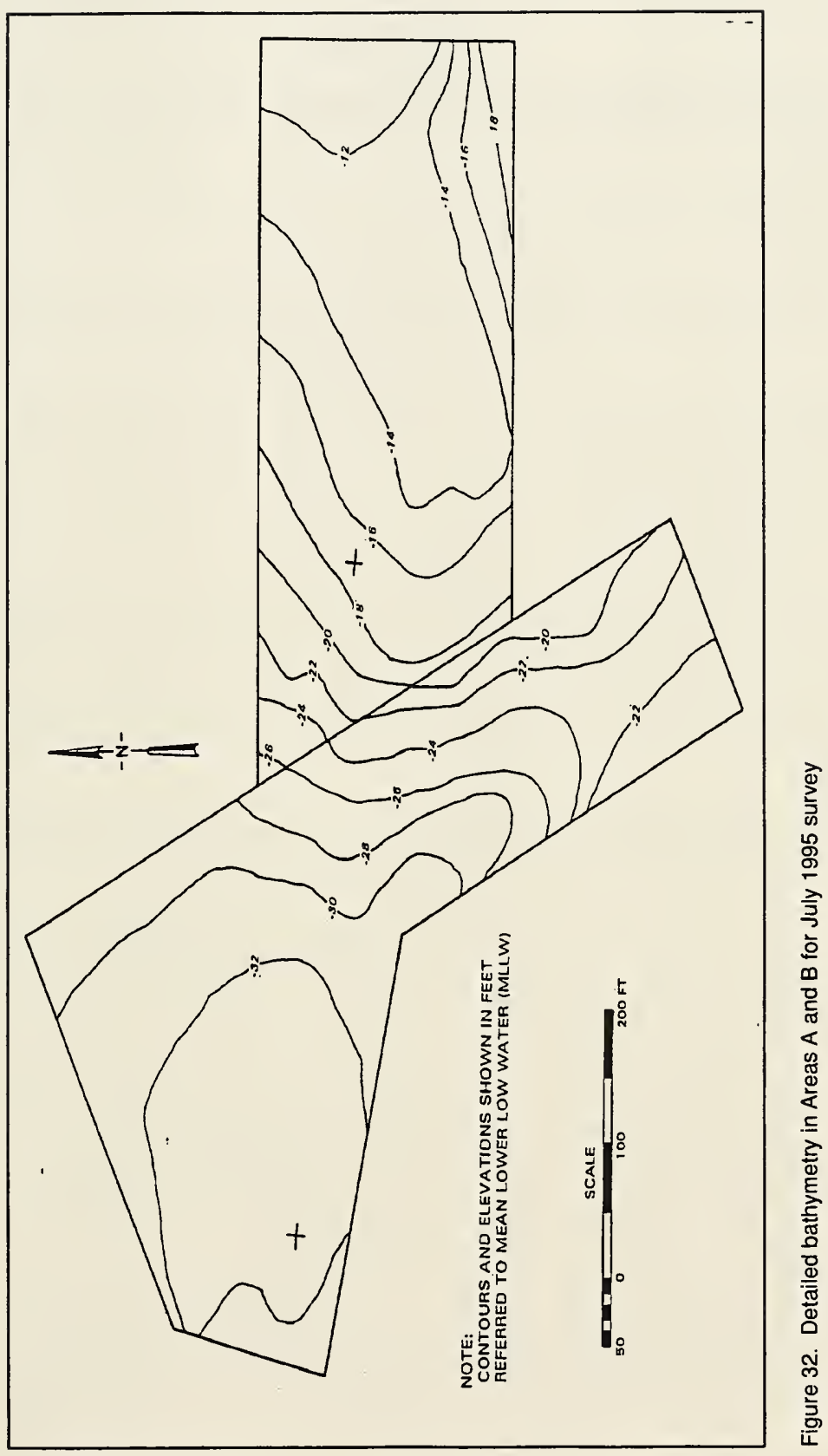




\section{SECTION A-A}

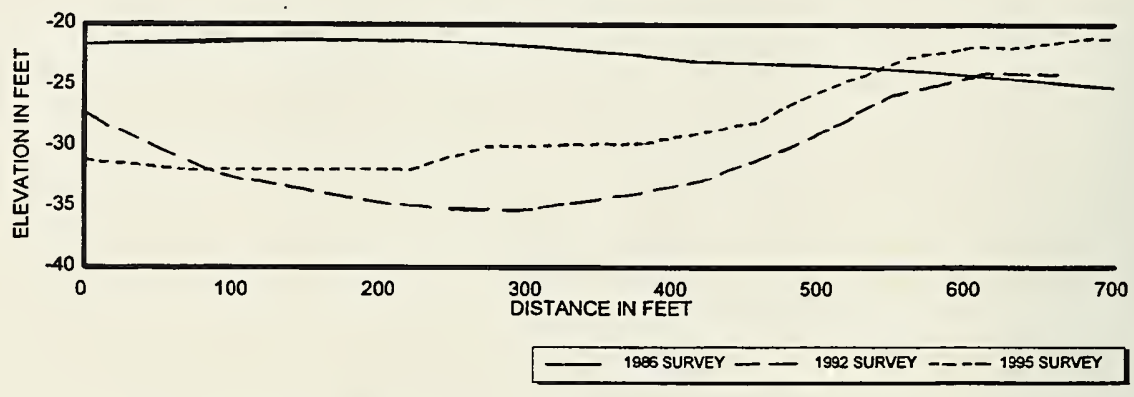

Figure 33. Cross sections through Area A, Section A-A for 1986, 1992, and 1995 surveys

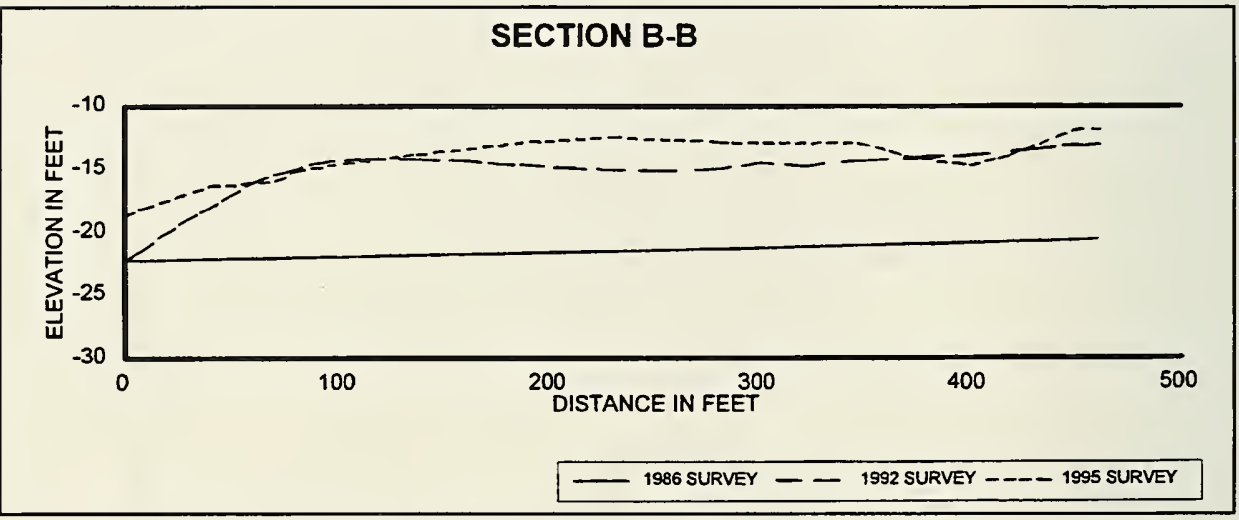

Figure 34. Cross sections through Area B, Section B-B for 1986, 1992, and 1995 surveys

The July 1995 survey was more comprehensive than the August 1992 survey in that it included more bathymetry inside the harbor. To determine changes as a result of the opening between the detached breakwater and the shoreline, the July 1995 survey was compared to pre-breakwater conditions (September 1986 survey). Contours of bathymetric changes in the lee of the eastern portion of the detached breakwater were prepared. Data indicate accretion of $2.4 \mathrm{~m}(8 \mathrm{ft})$ in areas inside the harbor between 1986 and 1995, as shown in Figure 38.

In summary, since construction of breakwater improvements at St. Paul Harbor, a scour hole initially formed at the head of the main breakwater extension similar to the one at the head of the structure prior to improvements. The scour hole has shifted in location somewhat, but has not undermined the toe of the breakwater head 


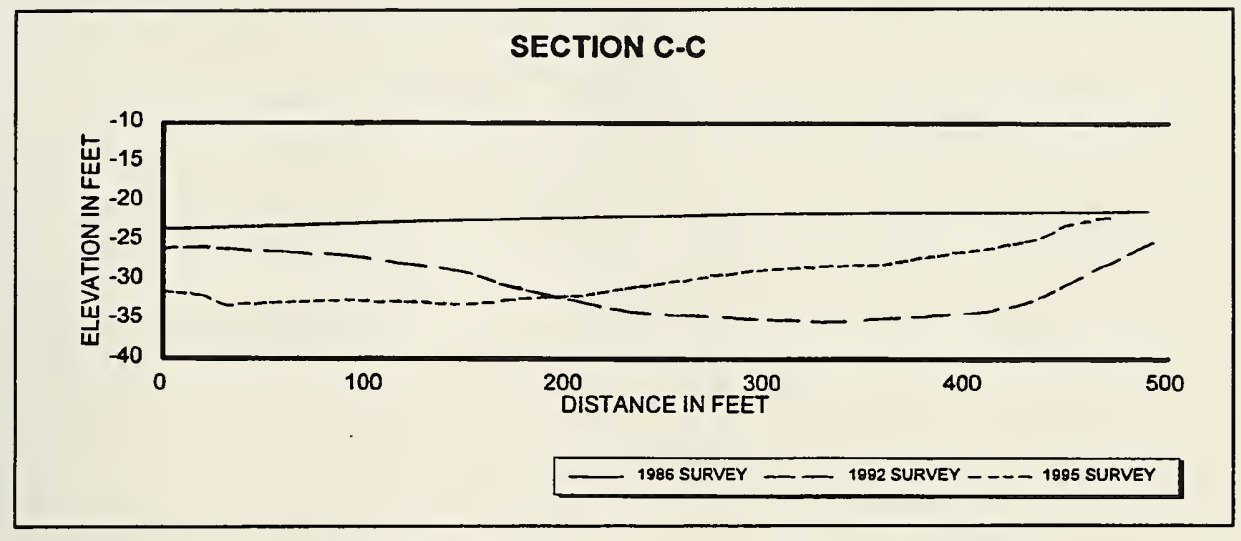

Figure 35. Cross sections through Area A, Section C-C for 1986, 1992, and 1995 surveys

or impacted the structure's stability. An accumulation of sediment has developed north of and adjacent to the detached breakwater with an underwater spit migrating toward the entrance channel. The underwater spit also has shifted in location somewhat, but no navigational difficulties have been experienced to this point. Inside the harbor, an accumulation has occurred due to material moving in between the east end of the detached breakwater and the shoreline. This material, however, is not depositing in the navigation channel or mooring areas.

Results of the three-dimensional model investigation predicted shoaling patterns precisely at St. Paul Harbor. The fixed-bed model could not be used to quantify the volume of sediment moving in the area, but could qualitatively predict sediment patterns and areas of accumulation. The model indicated sediment would accumulate north of and adjacent to the detached breakwater and migrate toward the entrance channel. It also indicated sediment would move into the harbor between the detached breakwater and the shoreline, but would not accumulate in the mooring areas. These predictions are shown in Figure 10. Also note that tracer material in the model was swept clean at the head of the breakwater extension, which would indicate possible scour conditions.

The broken/cracked armor unit survey of the St. Paul Harbor main breakwater during July 1993 revealed a total of 73 broken or cracked armor stones above the waterline. Of the 73 stones, 7 stones were located on the crest, 31 on the seaward slope, and 35 on the harbor-side slope. In the vicinity of the northernmost dock at sta $14+30$ (the seaward end of the additional layer of armor stones on the breakwater), some void areas between adjacent capstones were noted. The capstones had migrated away from each other.

The June 1994 survey yielded a total of 131 broken or cracked armor stones. Of these 131 units, 24 were located on the crest, 59 on the seaward slope, and 48 on the 


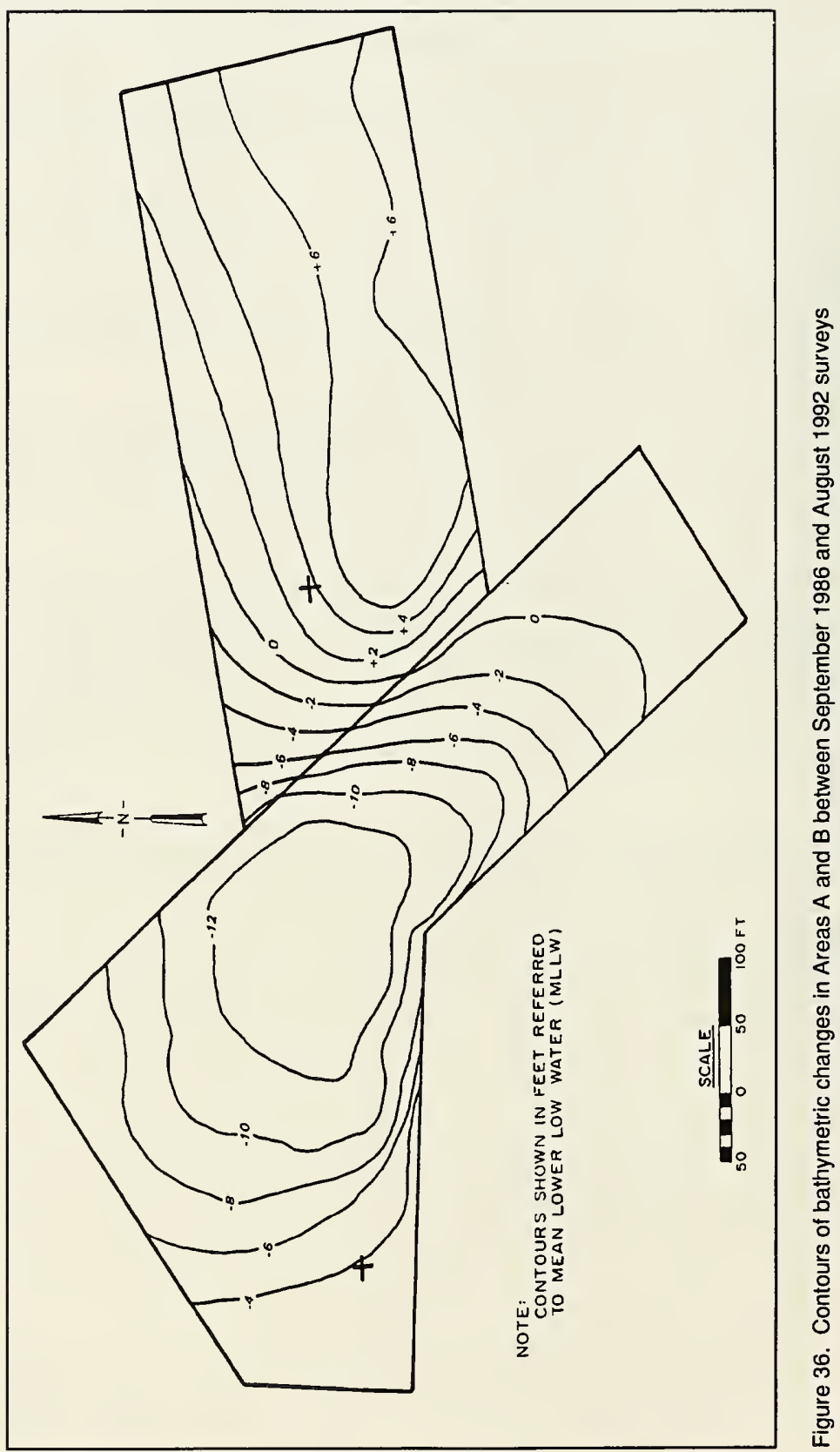




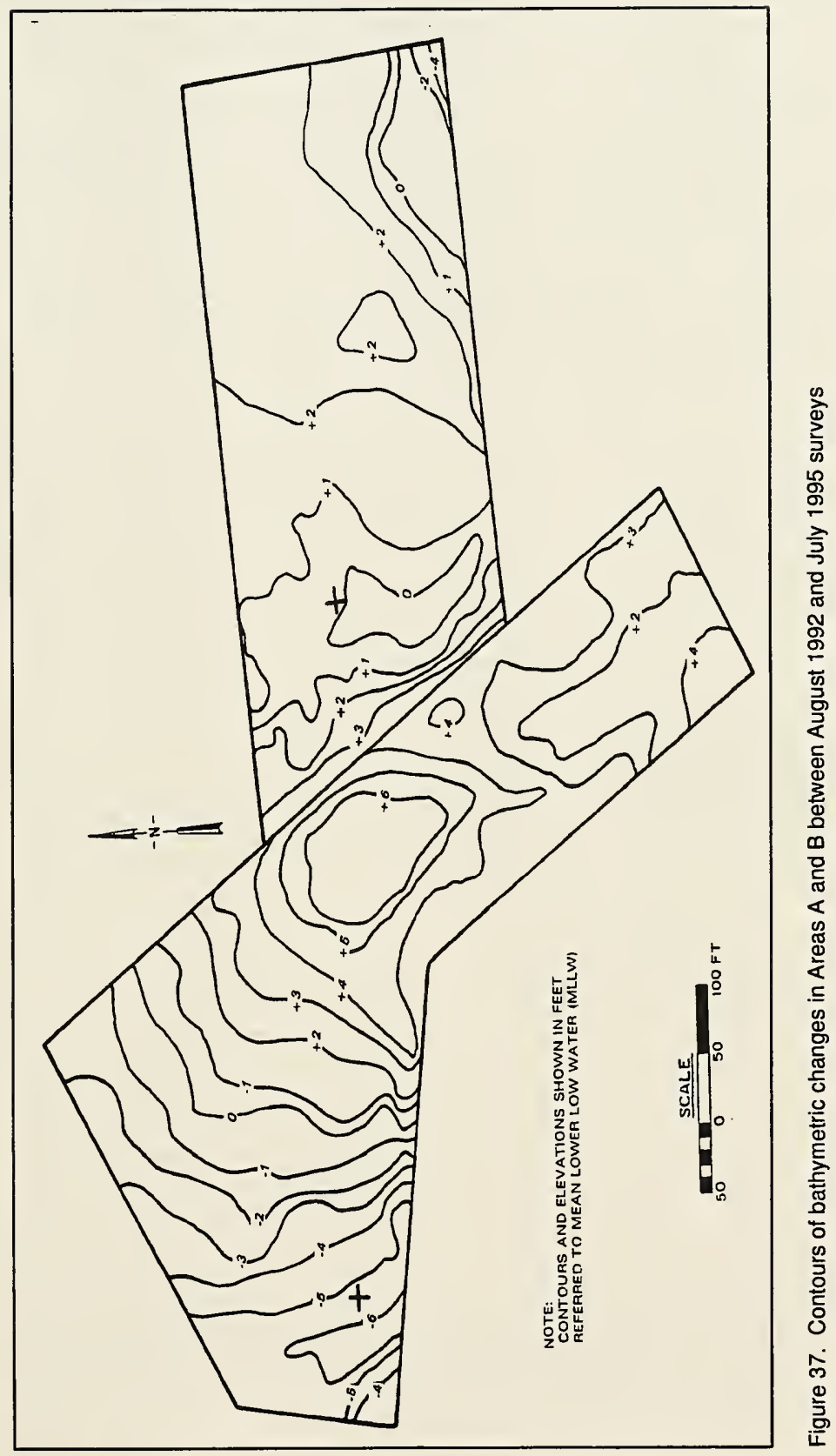




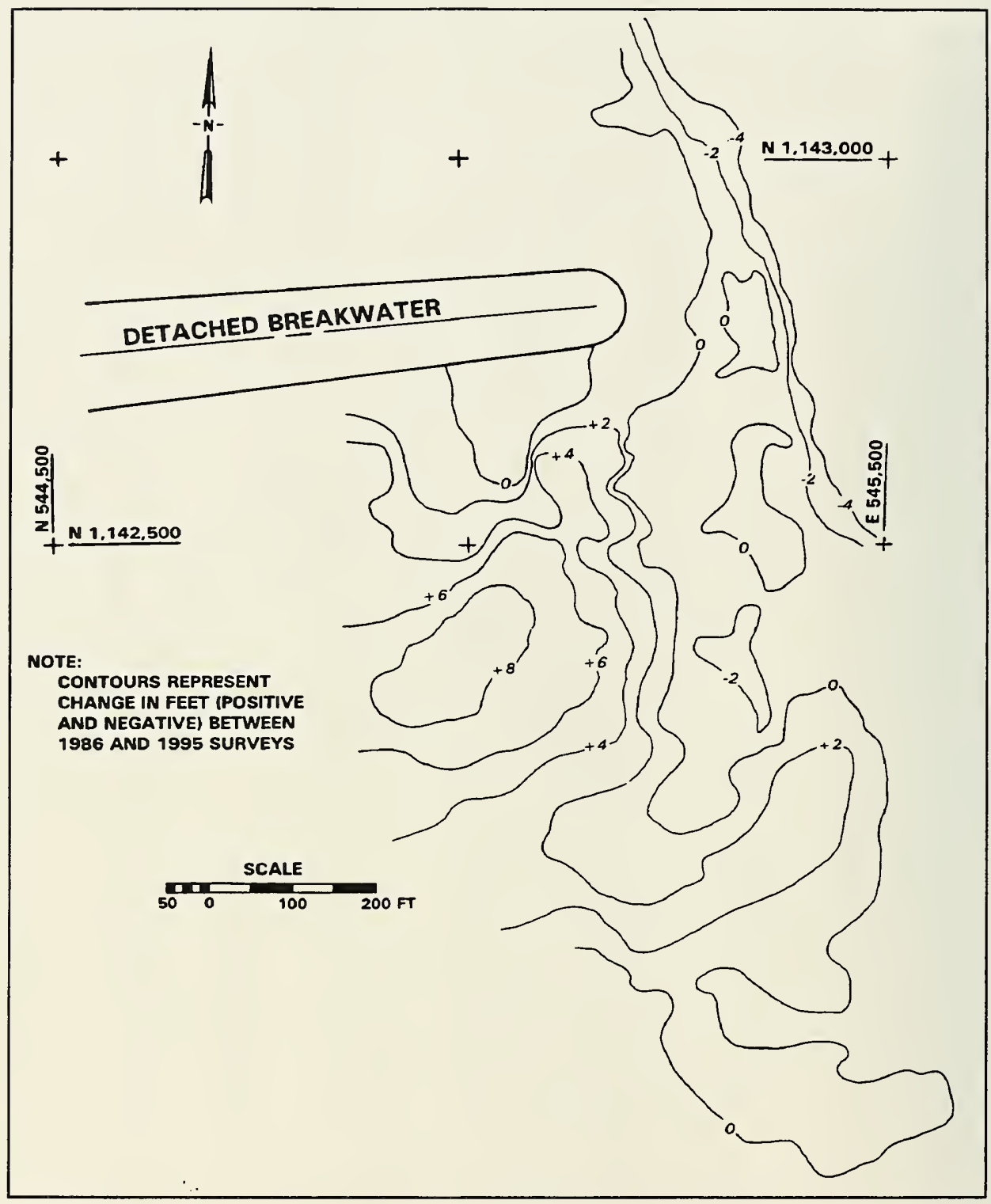

Figure 38. Contours of bathymetric changes in the lee of the eastern end of the detached breakwater between September 1986 and July 1995 
harbor-side slope. Observations during this inspection revealed that the separated capstones identified in 1993 (sta 14+30) were in about the same position.

During the broken/cracked armor unit survey of June 1995, a total of 191 broken or cracked armor stones were identified. Of the 191 stones, 35 broken/cracked armor units were located on the crest, 93 on the seaward slope, and 63 on the harbor-side slope. Several broken stones documented during previous surveys could not be found, indicating they had been moved away by wave and/or ice action. Also, it was observed that stones were missing along the water's edge on the seaward face of the structure at approximately stas $8+85$ and $9+50$. The 1994-95 winter was relatively severe with the presence of much floating ice. The voids at the waterline on the main breakwater were subsequently repaired by CENPA during the summer of 1995 using selected stones from the St. Paul Island quarry.

During the 1995 survey, a detailed geologic inspection of the breakwater was conducted by representatives of the Buffalo District. These personnel had experience in armor-stone quality and durability for coastal projects. Based on their analyses, 22 percent of the above-water stones are experiencing advanced degradation. This degradation is attributed to two factors. First, the project contains about 25 percent geologically unacceptable stone. The unacceptable stone is a light gray, vesicular banded basalt that has a marked platy structure. This stone likely came from the Smithrock Quarry in Camas, WA. About one half of this stone contains one or more significant cracks. These cracked stones exhibit common freeze-type and/or blasting crack characteristics. The delamination process is being enhanced at the St. Paul location because of the number of cycles of freeze-thaw and wet-dry conditions as well as large waves and sea ice action. Secondly, a significant amount of the stone on the structure is blast damaged. Fracture patterns and shape characteristics observed on much of the stone are common in overshot rock. As observed commonly in other breakwaters, this structure is predicted to continue to deteriorate, and the degradation rate is likely to increase as time progresses at this environmentally harsh location. It was also predicted that future project performance would be significantly impacted in the next 3 to 7 years and repairs should be expected.

During the breakwater survey of June 1996, a total of 230 broken/cracked armor stones were identified on the main breakwater. Of the 230 stones, 54 were located on the crest, 105 on the seaward slope, and 71 on the harbor-side slope. The rate of breakage was slightly less for this survey than for previous years; however, the harbor master indicated that the 1995-96 winter was milder than normal. As of the June 1996 survey, the approximate locations of broken/cracked armor stones along the outer portion of the breakwater are shown in Figure 39, and detailed data obtained during the survey are presented in Table 5 . Armor stone numbers identified in Figure 39 correspond to those listed in Table 5. As shown, only two broken armor units are located around the head of the structure. Armor stone for the breakwater head consisted of sound and durable granite from a quarry in Nome, AK. Shoreward of the breakwater head, broken stones were, generally, evenly distributed along the length of the structure. The survey showed that 49 percent of the broken stones were located on the shoreward half of the breakwater extension, and 51 percent on the outer half. About 23 percent of the observed broken stones were along the crest, 46 percent on the seaward slope, and 31 percent on the harbor-side 


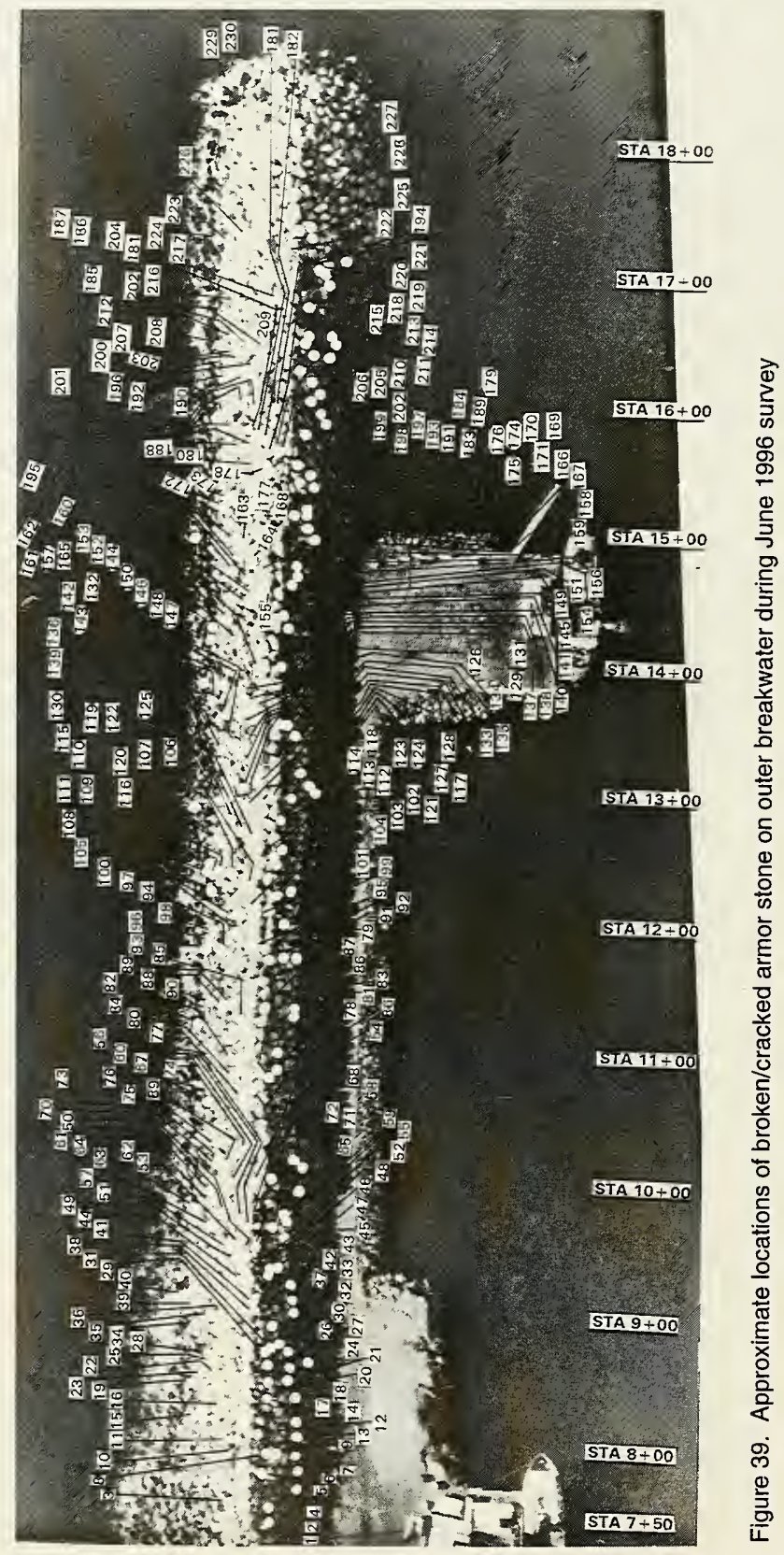


slope. The survey also showed that 50 percent of the broken stones were located on the upper half of the breakwater slopes (27 percent on the sea side and 23 percent on the harbor side); and 27 percent were on the lower half of the structure slopes (18 percent on the sea side and 9 percent on the harbor side). Views of representative types of breaks for the armor stones are shown in Figures 40 through 43.

Armor stones with hairline cracks on one side were not counted; only those that were cracked all the way through were considered a break for recording purposes. It was noted during the June 1996 survey that the separated capstones at sta 14+30, initially observed in July 1993, were about in the same position. Overall, the St. Paul Harbor main breakwater appears to be functional and in good condition.

Prior to the photogrammetric survey work for the St. Paul Harbor main break water, limited ground surveys were conducted. Monuments and targets established on the breakwater are shown in Figures 44 and 45 for the May 1994 and May 1996 surveys, respectively. Positions and elevations of the monuments/targets are presented in Table 6 for the two surveys. Although slight movement may have occurred between 1994 and 1996, the 1994 control points were used for truthing during the 1994 photogrammetric flight and the 1996 control points for the 1996 photogrammetric flight. In some cases, targets were re-established.

An example of photographic stereo pairs secured for the breakwater is shown in Figure 46. After orientation in the stereomodel to the monument and document data previously obtained, orthophotos were developed. Accuracy of photogrammetric spot elevations was on the order of $\pm 9 \mathrm{~cm}( \pm-0.03 \mathrm{ft})$. Figure 47 is a typical orthophoto for a portion of the breakwater. In addition, point plot maps were developed for the breakwater for the 1994 and 1996 surveys. An example of a point plot map showing elevations on the structure is shown in Figure 48. Areas where no elevations are shown are shadowed areas, or voids between the armor stones. Contour maps of the breakwater were developed from the DTM for the 1994 and 1996 surveys. Topography of the breakwater in 1996 is shown in Appendix A. Contours depicting the difference in elevations of the breakwater between 1994 and 1996 are shown in Appendix B, and cross sections of the breakwater in 1994 and 1996 are shown in Appendix C.

An examination of the breakwater topography for 1996 (Appendix A) reveals low areas along much of the breakwater. Only about 5 percent of the higher portion of the structure (sta $7+50-15+10$ ) is at its design el of $+11.3 \mathrm{~m}(+37 \mathrm{ft})$, and 9 percent of the lower portion of the breakwater (sta $15+10-18+00$ ) is at its design el of $+9.1 \mathrm{~m}(+30 \mathrm{ft})$. For the higher portion of the structure, the el of about 24 percent of the length of the breakwater is within $0.3 \mathrm{~m}(1.0 \mathrm{ft})$ of its design el, or between +11.0 and $+11.3 \mathrm{~m}(+36$ and $+37 \mathrm{ft})$; and approximately 66 percent of the structure is between +11.0 and $+11.3 \mathrm{~m}(+35$ and $+37 \mathrm{ft}$ ), or within $0.61 \mathrm{~m}(2 \mathrm{ft})$ of its design el. About 29 percent of the structure length is below $+10.7 \mathrm{~m}(+35 \mathrm{ft})$. Most of the low area (that below $+10.7 \mathrm{~m}(+35 \mathrm{ft})$ ) appears to be concentrated between stas $13+70$ and $15+10$. For the lower portion of the structure, the el of about 50 percent of the length of the breakwater is within $0.3 \mathrm{~m}(1.0 \mathrm{ft})$ of its design el, or between +8.8 and $+9.1 \mathrm{~m}(+29$ and $+30 \mathrm{ft})$; and approximately 89 percent of the structure is within $0.61 \mathrm{~m}(2.0 \mathrm{ft})$ of its design el, or between +8.5 and $+9.1 \mathrm{~m}(+28$ and $+30 \mathrm{ft})$. Only 2 percent of the structure length is below $+8.5 \mathrm{~m}(+28 \mathrm{ft})$. 


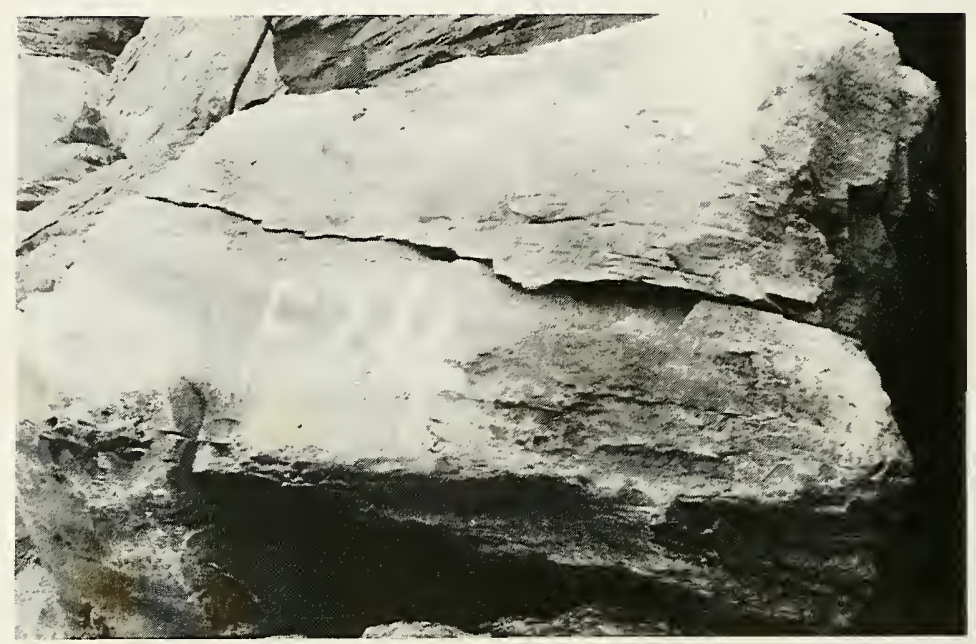

Figure 40. View of broken armor stone on St. Paul Harbor breakwater (station 10+21)

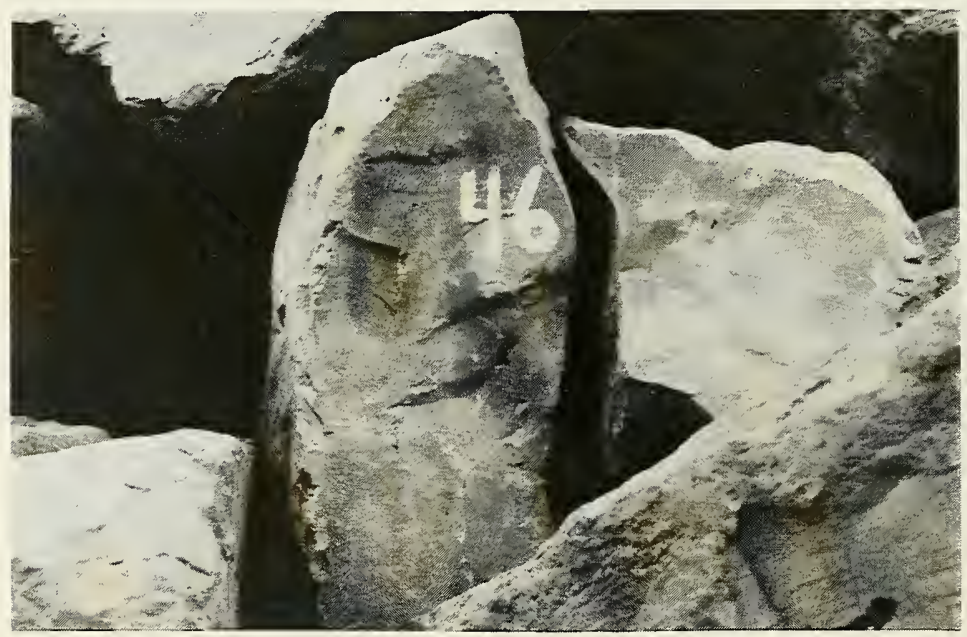

Figure 41. View of broken armor stone on St. Paul Harbor breakwater (station 11+78)

Contours showing the difference in elevation of the St. Paul Harbor breakwater extension from 1994 to 1996 (Appendix B) reveal very slight change. Results indicate essentially no change along the crown of the structure. In the vicinity of sta $9+50$, a change up to $0.9 \mathrm{~m} \mathrm{(} 3 \mathrm{ft}$ ) occurred along the waterline on the sea side of 


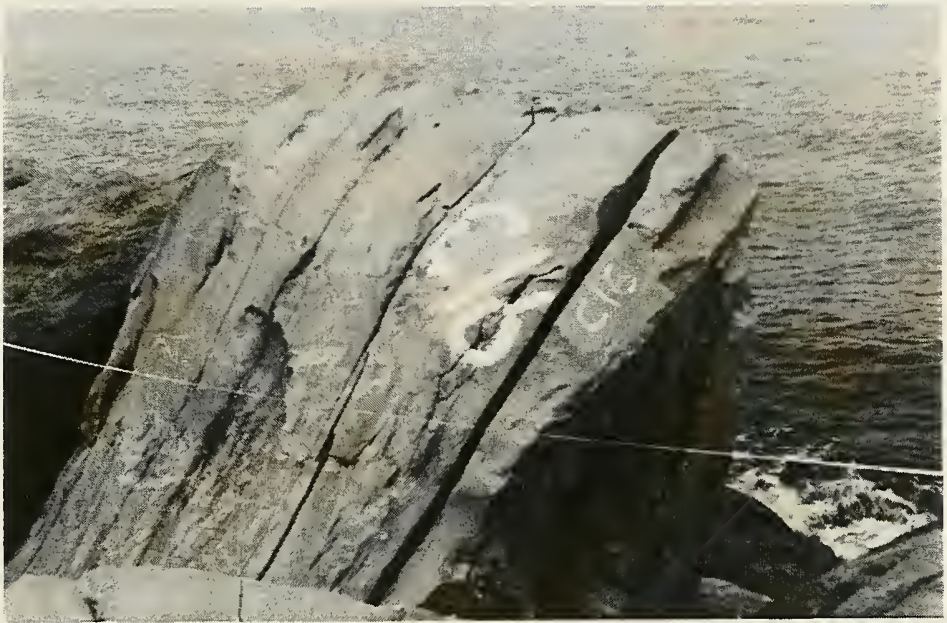

Figure 42. View of broken armor stone on St. Paul Harbor breakwater (station 11+87)

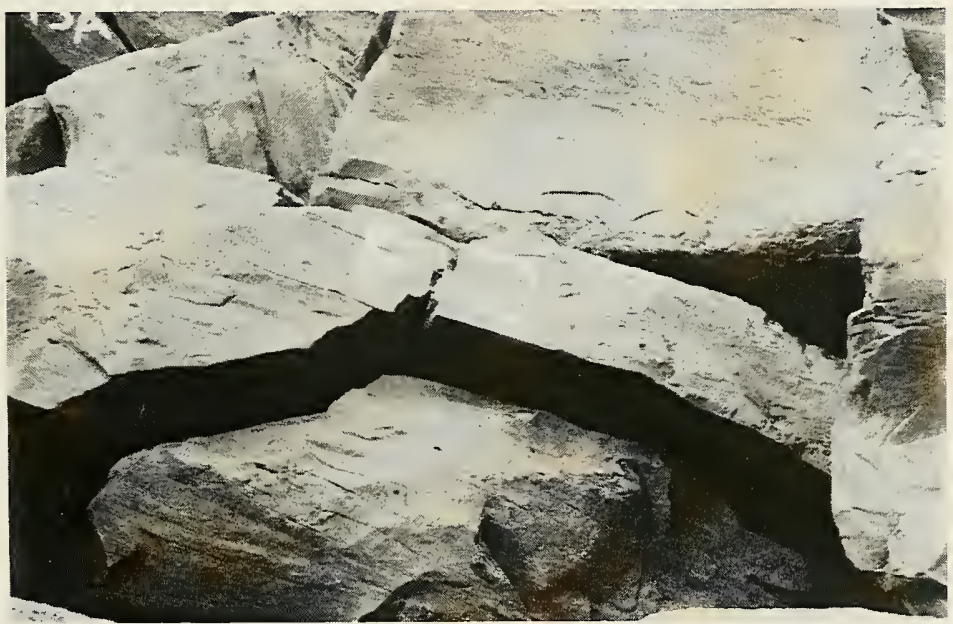

Figure 43. View of broken armor stone on St. Paul Harbor breakwater (station 17+34)

the structure. This was one of the areas, however, where emergency repairs were made in 1995 following the broken armor stone survey. Other changes (between 0.3 and $0.9 \mathrm{~m}$ ( 1 and $3 \mathrm{ft}$ ) ) generally occurred on the harbor side of the breakwater. These data indicate no settlement of the structure between 1994 and 1995. 

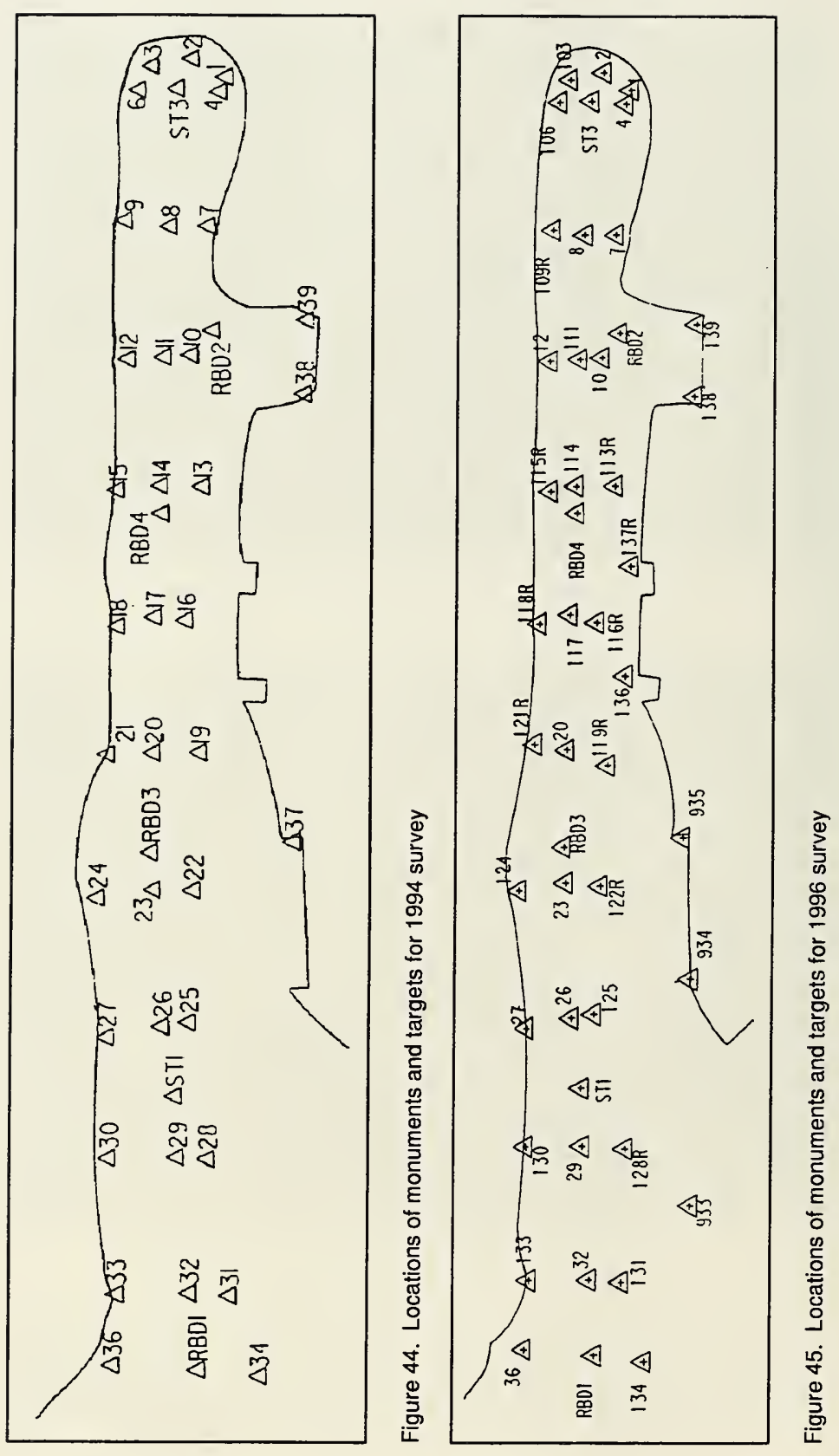

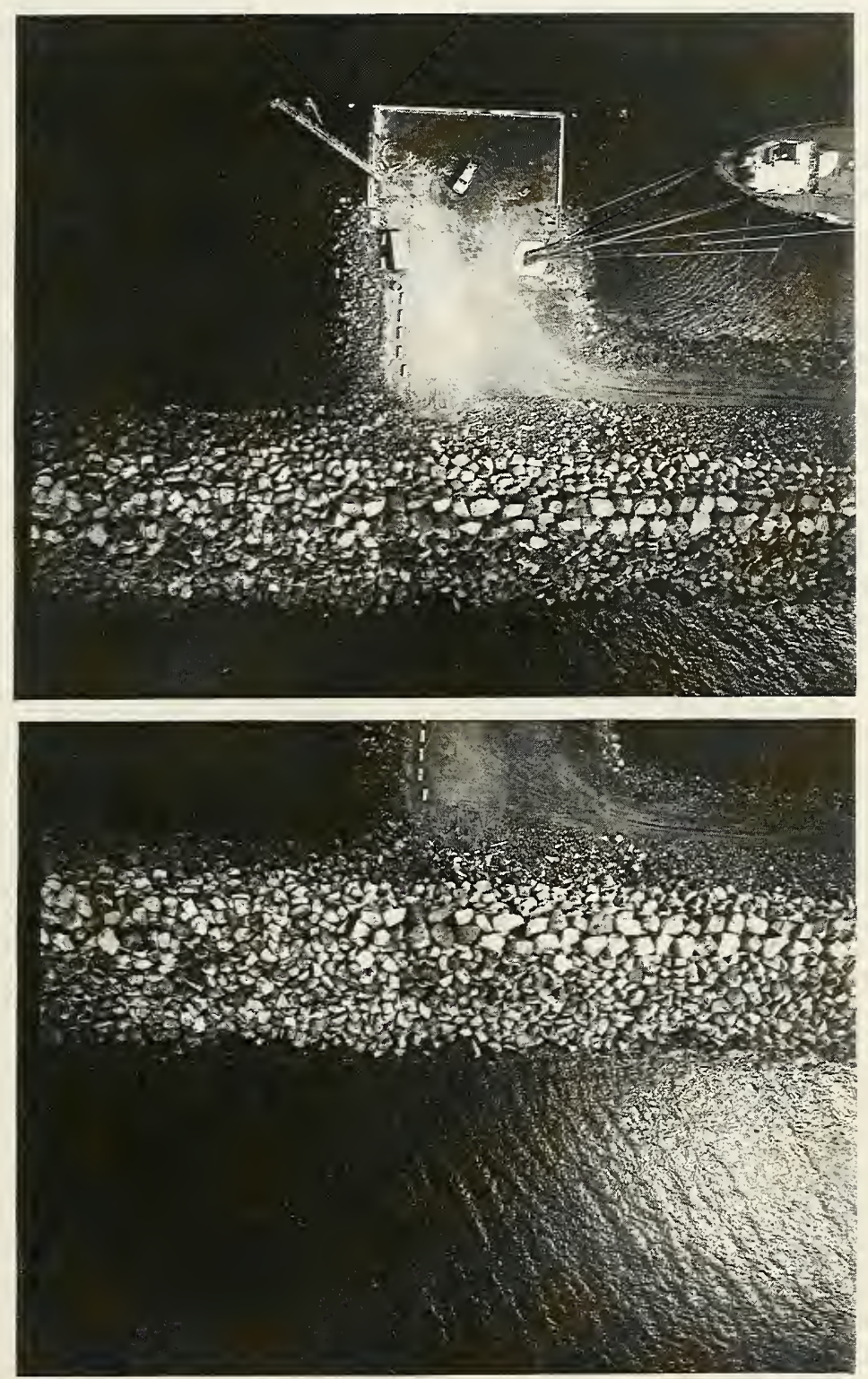

Figure 46. Example of stereo pair photos for a portion of the breakwater in May 1996 


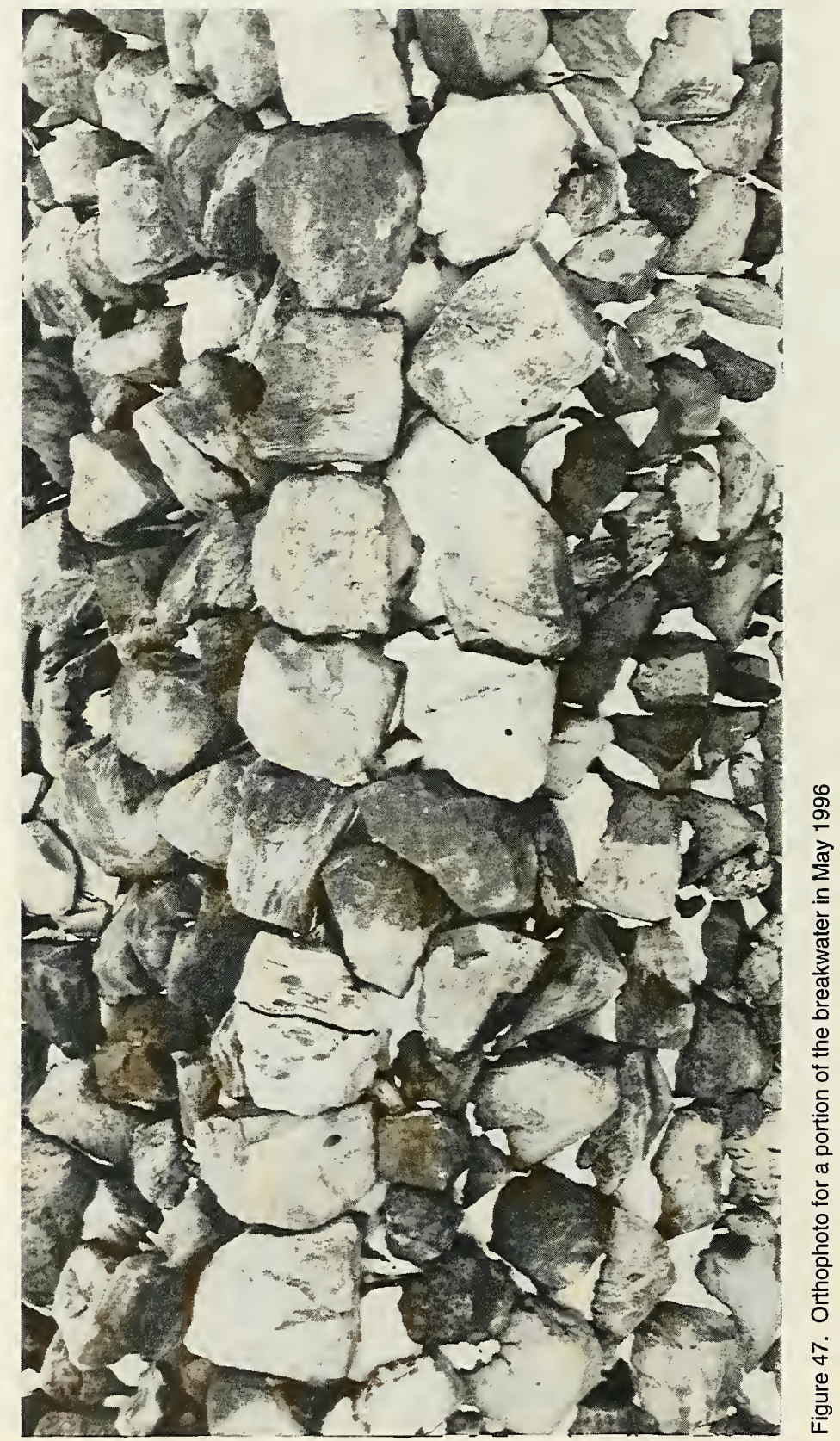




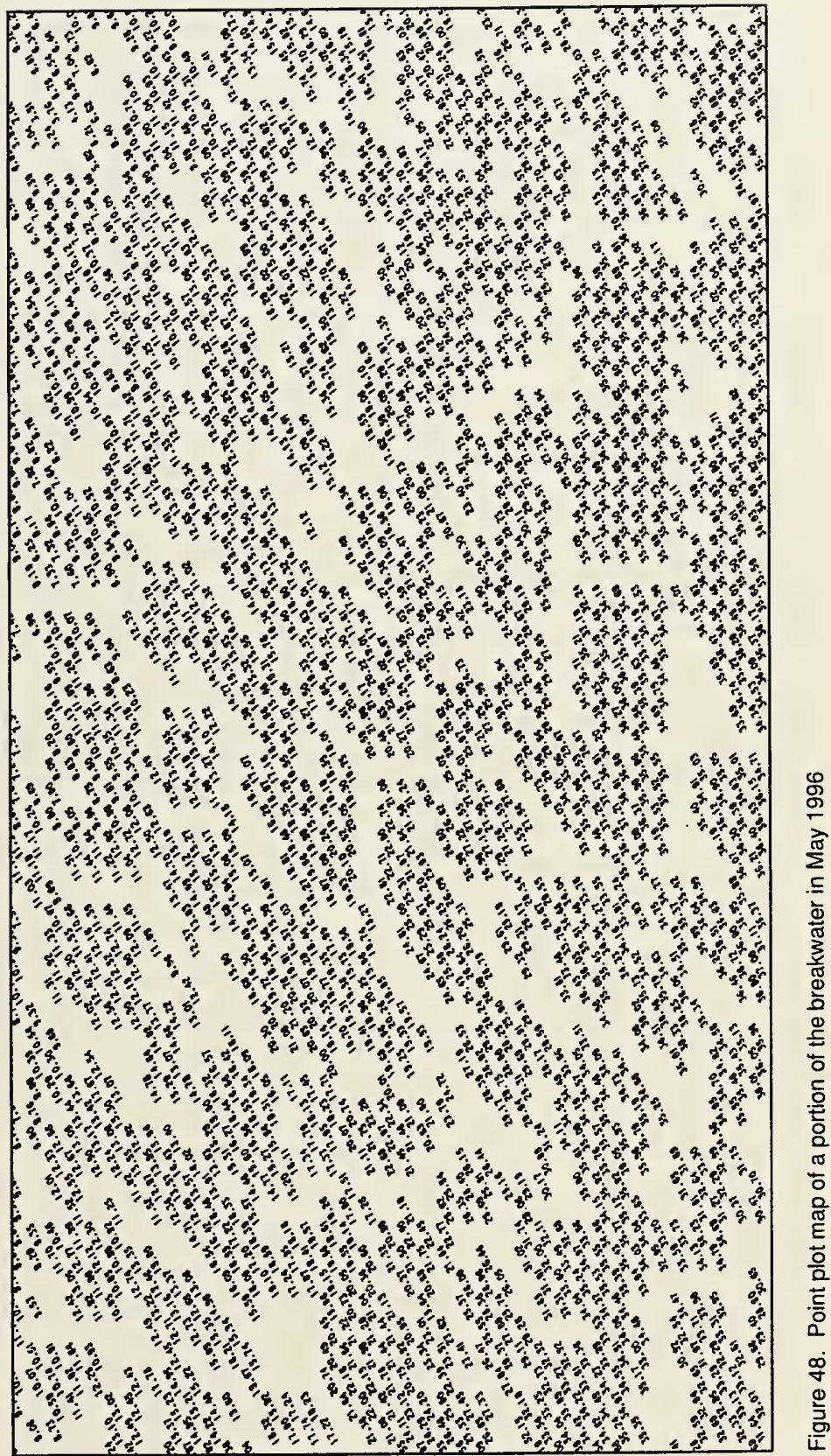


Examination of the data in Appendix $\mathrm{C}$ reveals that cross sections of the breakwater were similar in both 1994 and 1996. Accretion of stone along the toe of the harbor-side slope of the structure is shown at stas $11+00,12+00$, and $13+00$. This was an accumulation of small stones which were noted during the 1996 broken armor stone survey. CENPA personnel inspected the breakwater in November 1996 after a large storm and determined the small stones coming out of the structure were chinking stone used during breakwater construction. Approximately a 1.8-m (6-ft) layer of this small stone was placed directly under the armor layer during construction.

In summary, the photogrammetric surveys of the St. Paul Harbor breakwater extension were very effective in accurately mapping the above-water portion of the structure and showing changes in el occurring from 1994 to 1996. Results indicated that low areas existed along the length of the breakwater. The higher portion of the breakwater extension seaward of the roadway was at least $0.61 \mathrm{~m}(2 \mathrm{ft})$ below its design el over 29 percent of the length of the structure. Only 5 percent of the breakwater length was at, or above, its design el. This could contribute to the undesirable overtopping of the breakwater being experienced. As stated earlier, quantifiable overtopping rates were not obtained during the monitoring effort. However, it would have been difficult to correlate them with the two-dimensional model results had they been secured. The elevation of most of the prototype breakwater in this vicinity is below its $+11.3-\mathrm{m}(+37-\mathrm{ft})$ design, and the el of the structure tested in, and recommended by, the model was $+11.9 \mathrm{~m}(+39 \mathrm{ft})$. For the outer portion of the breakwater extension, 9 percent of the structure length is at, or above, its design el

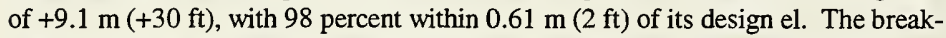
water extension may have subsided after initial construction, causing the lowerthan-design elevations; however, essentially no change in el occurred between 1994 and 1996 based on results of the photogrammetric analysis. 


\section{Conclusions and Recommendations}

\section{Conclusions}

Failure to obtain incident wave data outside the harbor had a negative impact on analysis of some of the other data collected during the monitoring effort. Incident wave data were required for correlation with wave data obtained inside the harbor, wave runup, and wave overtopping data to validate design methods and procedures.

Wave height data obtained inside the harbor (from the Unisea vessel) appeared to validate the three-dimensional model study. Maximum significant wave heights measured in the immediate lee of the main breakwater during storm wave events were in agreement with those predicted during the physical model study.

The videotape analysis used to obtain wave runup data along the face of the St. Paul Harbor main breakwater was successful, except during periods of low visibility. The technique is relatively low cost, logistically simple, and provides relatively accurate measurements.

Trends in wave hindcast data obtained outside the harbor (to define incident wave conditions) correlated reasonably well with runup data in a qualitative sense (i.e. larger wave heights correlated with higher runup and smaller wave heights with low runup). The absolute values of the hindcast significant wave heights, however, appeared to be substantially lower than the waves experienced in the prototype based on runup values measured, overtopping observed, and local forecasts.

Since construction of breakwater improvements, a scour hole has formed at the head of the main breakwater extension, sediment has accumulated north of and adjacent to the detached breakwater (forming an underwater spit that is migrating toward the entrance channel), and sediment has moved into the harbor between the detached breakwater and the shoreline. To this point, the scour hole has not impacted the structure's stability, nor has the underwater spit interfered with navigation. Accretion inside the harbor has not occurred in the federal channel or mooring areas. Sediment patterns in the harbor, as predicted by the threedimensional model, were validated by the prototype data. 
The St. Paul Harbor main breakwater is currently functioning in an acceptable manner and is in good condition structurally; however, the armor stone continues to degrade. The number of broken/cracked armor stones on the 320-m-long (1,050-ftlong) breakwater extension increased from 73 in July 1993 to 230 in June 1996. A geologic assessment indicated that about 25 percent of the original stone placed was geologically unacceptable, and a significant amount of the stone on the structure was blast damaged. Continued deterioration is predicted due to freeze-thaw and wet-dry cycles as well as large waves and sea ice action.

Photogrammetric analysis of the St. Paul Harbor main breakwater proved to be an excellent tool in mapping the above-water portion of the structure extension and quantifying changes in elevation. Results revealed most of the breakwater extension was below its design elevation. Almost a third of the higher portion of the breakwater seaward of the harbor roadway was at least $0.61 \mathrm{~m}(2 \mathrm{ft})$ below its design el of $+11.3 \mathrm{~m}(+37 \mathrm{ft})$. Analysis also indicated essentially no change in el of the breakwater crown between 1994 and 1996.

\section{Recommendations}

Extra precautions should be taken when monitoring future projects in extremely high-wave-energy environments to ensure that required data are obtained. The loss of the prototype wave gauges and the destruction of the wave overtopping container reduced the value of the monitoring effort at St. Paul Harbor. In the future, in-depth research of conditions should be conducted to assure success.

When monitoring projects in remote areas, logistical problems may be experienced. Delivery dates and/or availability of equipment, supplies, materials, etc. are uncertain. These problems should be considered during the development of future monitoring plans in remote locations. Additional time and costs associated with these problems also should be considered.

The St. Paul Harbor main breakwater should be observed very closely due to the continued degradation of armor stone on the structure. Preparatory work for repair considerations should be initiated since the deterioration rate is not expected to decrease. When repair or rehabilitation occurs, the highest grade of geologically acceptable stone should be placed above the waterline. Inspection of 100 percent of shot stone for near-invisible hairline blast fractures also should be conducted by skilled personnel. Only the most sound and durable stone should be used in this extremely harsh environment. 


\section{References}

Bottin, R. R., Jr., and Mize, M. G. (1988). "St. Paul Harbor, St. Paul Island, Alaska, design for wave and shoaling protection; hydraulic model investigation," Technical Report CERC-88-13, U.S. Army Engineer Waterways Experiment Station, Vicksburg, MS.

Ebersole, B. A. (1985). "Refractional-diffraction model for linear water waves," Journal of Waterway, Port, Coastal, and Ocean Engineering, American Society of Civil Engineers, New York, III (6), 985-999.

Hathaway, K., Howd, P., and Oltman-Shay, J. "Infragravity waves in the nearshore zone," in preparation, U.S. Army Engineer Waterways Experiment Station, Vicksburg, MS.

Howell, G. L. (1993). "Design of an in-situ directional wave gage for one year deployments." WAVES '93, Proceedings of the Second International Symposium on Ocean Wave Measurement and Analysis. American Society of Civil Engineers, New York, 264-276.

Hubertz, J. M. (1992). "User's guide to Wave Information Studies (WIS) wave model, Version 2.0," WIS Report 27, U.S. Army Engineer Waterways Experiment Station, Vicksburg, MS.

Noda, E. K. (1972). "Equilibrium beach profile scale-model relationship," Journal, Waterways, Harbors, and Coastal Engineering Division, American Society of Civil Engineers, New York, 98 (WW4), 511-528.

Shore protection manual. (1984). 4th ed., 2 Vol, U.S. Army Engineer Waterways Experiment Station, U.S. Government Printing Office, Washington, DC.

Tetra Tech, Inc. (1987). "St. Paul Harbor and breakwater technical design report," TC-3263-07, Pasadena, CA; prepared for the City of St. Paul, Alaska.

U.S. Army Engineer District, Alaska. (1981). "St. Paul Island, Alaska; harbor feasibility report," Anchorage, AK. 
Ward, D. L. (1988). "St. Paul Harbor breakwater stability study, St. Paul, Alaska; Hydraulic Model Investigation," Technical Report CERC-88-10, U.S. Army Engineer Waterways Experiment Station, Vicksburg, MS. 


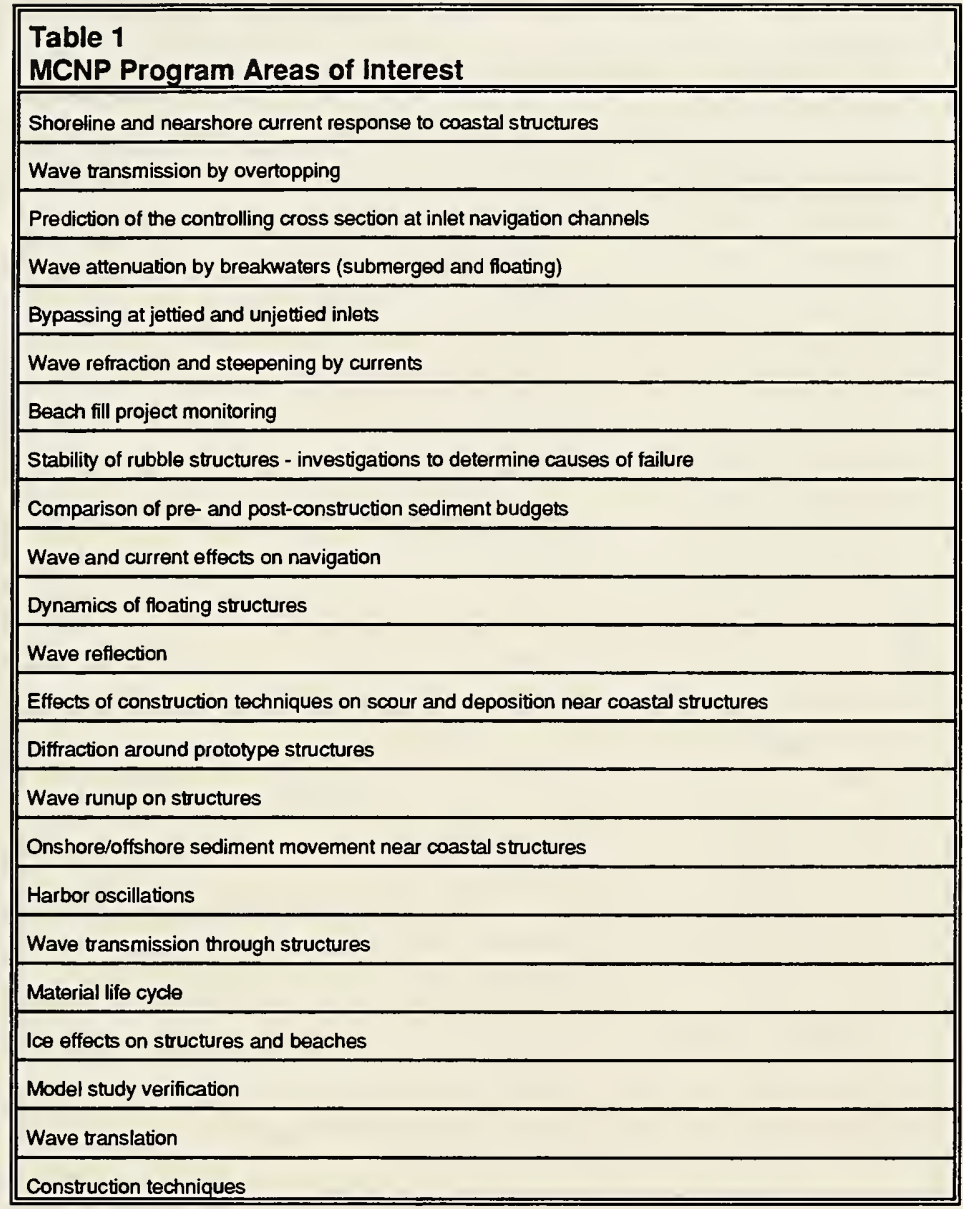




\begin{tabular}{|c|c|c|c|c|c|}
\hline \multicolumn{6}{|c|}{$\begin{array}{l}\text { Table } 2 \\
\text { Significant Wave Heights and Peak Periods from Unisea Data }\end{array}$} \\
\hline \multicolumn{2}{|c|}{ Observation Date and Time } & \multicolumn{2}{|c|}{ Gauge Number 276} & \multicolumn{2}{|c|}{ Gauge Number 277} \\
\hline Date & Time & $T_{p}(\sec )$ & $H, \mathbf{m}(t)$ & $T_{p}(\mathrm{sec})$ & $H, m(f t)$ \\
\hline 5 Sep 94 & 2302 & 10.7 & $0.15(0.5)$ & & \\
\hline 5 Sep 94 & 2319 & & & 10.7 & $0.15(0.5)$ \\
\hline 6 Sep 94 & 1153 & & & 9.1 & $0.15(0.5)$ \\
\hline 6 Sep 94 & 1810 & & & 9.1 & $0.15(0.5)$ \\
\hline 13 Sep 94 & 1133 & & & 10.2 & $0.30(1.0)$ \\
\hline 13 Sep 94 & 1234 & 11.6 & $0.30(1.0)$ & & \\
\hline 13 Sep 94 & 1749 & & & 11.6 & $0.34(1.1)$ \\
\hline 13 Sep 94 & 1851 & 10.9 & $0.37(1.2)$ & & \\
\hline 14 Sep 94 & 0006 & & & 11.6 & $0.27(0.9)$ \\
\hline 14 Sep 94 & 0109 & 10.2 & $0.24(0.8)$ & & \\
\hline 14 Sep 94 & 0623 & & & 10.8 & $0.18(0.6)$ \\
\hline 14 Sep 94 & 0726 & 10.2 & $0.18(0.6)$ & & \\
\hline 14 Sep 94 & 1240 & & & 10.2 & $0.15(0.5)$ \\
\hline 14 Sep 94 & 1343 & 9.7 & $0.15(0.5)$ & & \\
\hline 14 Sep 94 & 1857 & & & 9.7 & $0.15(0.5)$ \\
\hline 14 Sep 94 & 2000 & 9.7 & $0.15(0.5)$ & & \\
\hline 15 Sep 94 & 0114 & & & 10.7 & $0.18(0.6)$ \\
\hline 15 Sep 94 & 0217 & 10.2 & $0.15(0.5)$ & & \\
\hline 16 Sep 94 & 1456 & & & 9.1 & $0.15(0.5)$ \\
\hline 1 Oct 94 & 0316 & 11.6 & $0.09(0.3)$ & & \\
\hline 1 Oct 94 & 1550 & 12.5 & $0.12(0.4)$ & & \\
\hline 3 Oct 94 & 1808 & 10.7 & $0.09(0.3)$ & & \\
\hline 7 Dec 94 & 1443 & 11.6 & $0.09(0.3)$ & & \\
\hline 7 Dec 94 & 2100 & 14.6 & $0.15(0.5)$ & & \\
\hline 8 Dec 94 & 0318 & 10.2 & $0.12(0.4)$ & & \\
\hline 8 Dec 94 & 0936 & 9.1 & $0.21(0.7)$ & & \\
\hline 8 Dec 94 & 1553 & 10.2 & $0.21(0.7)$ & & \\
\hline 8 Dec 94 & 2211 & 10.2 & $0.21(0.7)$ & & \\
\hline 9 Dec 94 & 0429 & 10.2 & $0.18(0.6)$ & & \\
\hline 9 Dec 94 & 1046 & 10.2 & $0.21(0.7)$ & & \\
\hline
\end{tabular}




\begin{tabular}{|c|c|c|c|c|c|}
\hline \multicolumn{6}{|c|}{ Table 2 (Continued) } \\
\hline \multicolumn{2}{|c|}{ Observation Date and Time } & \multicolumn{2}{|c|}{ Gauge Number 276} & \multicolumn{2}{|c|}{ Gauge Number 277} \\
\hline Date & Time & $\mathrm{T}_{\mathrm{p}}(\mathrm{sec})$ & $\mathrm{H}_{\mathrm{a}} \mathrm{m}(\mathrm{ft})$ & $T_{p}$ (sec) & $H, m(t)$ \\
\hline 9 Dec 94 & 1704 & 10.2 & $0.18(0.6)$ & & \\
\hline 9 Dec 94 & 2322 & 11.6 & $0.21(0.7)$ & & \\
\hline 10 Dec 94 & 0539 & 11.6 & $0.18(0.6)$ & & \\
\hline 10 Dec 94 & 1157 & 10.2 & $0.58(1.9)$ & & \\
\hline 10 Dec 94 & 1815 & 10.2 & $0.34(1.1)$ & & \\
\hline 11 Dec 94 & 0032 & 10.2 & $0.24(0.8)$ & & \\
\hline 11 Dec 94 & 0650 & 11.6 & $0.21(0.7)$ & & \\
\hline 11 Dec 94 & 1308 & 10.2 & $0.24(0.8)$ & & \\
\hline 11 Dec 94 & 1925 & 17.7 & $0.52(1.7)$ & & \\
\hline 12 Dec 94 & 0143 & 17.7 & $0.58(1.9)$ & & \\
\hline 12 Dec 94 & 0801 & 17.7 & $0.49(1.6)$ & & \\
\hline 12 Dec 94 & 1418 & 14.6 & $0.40(1.3)$ & & \\
\hline 12 Dec 94 & 2036 & 9.7 & $0.30(1.0)$ & & \\
\hline 13 Dec 94 & 0254 & 14.6 & $0.30(1.0)$ & & \\
\hline 13 Dec 94 & 0911 & 14.6 & $0.24(0.8)$ & & \\
\hline 13 Dec 94 & 1529 & 14.6 & $0.21(0.7)$ & & \\
\hline 13 Dec 94 & 2147 & 13.4 & $0.15(0.5)$ & & \\
\hline 14 Dec 94 & 0404 & 11.6 & $0.15(0.5)$ & & \\
\hline 16 Dec 94 & 0008 & 12.8 & $0.09(0.3)$ & & \\
\hline 16 Dec 94 & 0626 & 10.7 & $0.18(0.6)$ & & \\
\hline 16 Dec 94 & 1244 & 10.7 & $0.15(0.5)$ & & \\
\hline 16 Dec 94 & 1901 & 10.7 & $0.15(0.5)$ & & \\
\hline 17 Dec 94 & 2012 & 12.5 & $0.09(0.3)$ & & \\
\hline 18 Dec 94 & 1505 & 11.6 & $0.09(0.3)$ & & \\
\hline 18 Dec 94 & 2123 & 10.7 & $0.12(0.4)$ & & \\
\hline 19 Dec 94 & 0340 & 10.7 & $0.12(0.4)$ & & \\
\hline 19 Dec 94 & 1616 & 9.8 & $0.15(0.5)$ & & \\
\hline 23 Dec 94 & 1441 & 11.6 & $0.09(0.3)$ & & \\
\hline 23 Dec 94 & 2058 & 11.6 & $0.27(0.9)$ & & \\
\hline 24 Dec 94 & 0316 & 11.6 & $0.15(0.5)$ & & \\
\hline & & & & & (She \\
\hline
\end{tabular}




\begin{tabular}{|c|c|c|c|c|c|}
\hline \multicolumn{6}{|c|}{ Table 2 (Continued) } \\
\hline \multicolumn{2}{|c|}{ Observation Date and Time } & \multicolumn{2}{|c|}{ Gauge Number 276} & \multicolumn{2}{|c|}{ Gauge Number 277} \\
\hline Dale & Time & $T_{p}(s e c)$ & $H, m(f t)$ & $T_{p}$ (sec) & $H_{2} m(t)$ \\
\hline 24 Dec 94 & 0934 & 10.7 & $0.09(0.3)$ & & \\
\hline 6 Feb 95 & $\infty 001$ & 10.2 & $0.18(0.6)$ & & \\
\hline 6 Feb 95 & 0002 & 10.9 & $0.18(0.6)$ & & \\
\hline 6 Feb 95 & 0003 & 10.6 & $0.15(0.5)$ & & \\
\hline 6 Feb 95 & 0009 & 11.6 & $0.15(0.5)$ & & \\
\hline 18 Mar 95 & 0609 & & & 7.5 & $0.21(0.7)$ \\
\hline $18 \mathrm{Mar} 95$ & 1226 & & & 7.5 & $0.18(0.6)$ \\
\hline 19 Mar 95 & 0100 & & & 8 & $0.18(0.6)$ \\
\hline $19 \operatorname{Mar} 95$ & 0716 & & & 9.1 & $0.21(0.7)$ \\
\hline 19 Mar 95 & 1333 & & & 8.5 & $0.12(0.4)$ \\
\hline $19 \mathrm{Mar} 95$ & 1950 & & & 8.5 & $0.12(0.4)$ \\
\hline 20 Mar 95 & 0207 & & & 9.1 & $0.12(0.4)$ \\
\hline 20 Mar 95 & 0824 & & & 9.1 & $0.15(0.5)$ \\
\hline 20 Mar 95 & 1441 & & & 8.5 & $0.12(0.4)$ \\
\hline 20 Mar 95 & 2057 & & & 8.5 & $0.12(0.4)$ \\
\hline 21 Mar 95 & 0314 & & & 8.5 & $0.12(0.4)$ \\
\hline $21 \mathrm{Mar} 95$ & 2205 & & & 8 & $0.15(0.5)$ \\
\hline $22 \operatorname{Mar} 95$ & 1038 & & & 8.5 & $0.43(1.4)$ \\
\hline 22 Mar 95 & 1655 & & & 9.1 & $0.15(0.5)$ \\
\hline 22 Mar 95 & 2312 & & & 8.5 & $0.18(0.6)$ \\
\hline 28 Mar 95 & 1106 & & & 9.1 & $0.15(0.5)$ \\
\hline 28 Mar 95 & 1722 & & & 9.1 & $0.21(0.7)$ \\
\hline $29 \operatorname{Mar} 95$ & 0556 & & & 8.5 & $0.18(0.6)$ \\
\hline 5 Apr 95 & 0114 & & & 8.5 & $0.21(0.7)$ \\
\hline 5 Apr 95 & 0350 & 8.5 & $0.18(0.6)$ & & \\
\hline 5 Apr 95 & 0731 & & & 8.5 & $0.15(0.5)$ \\
\hline 5 Apr 95 & 1007 & 8.5 & $0.18(0.6)$ & & \\
\hline 5 Apr 95 & 1347 & & & 8.5 & $0.15(0.5)$ \\
\hline 5 Apr 95 & 1624 & 8.5 & $0.24(0.8)$ & & \\
\hline 5 Apr 95 & 2004 & & & 8.5 & $0.15(0.5)$ \\
\hline
\end{tabular}




\begin{tabular}{|c|c|c|c|c|c|}
\hline \multicolumn{2}{|c|}{ Observation Date and Time } & \multicolumn{2}{|c|}{ Gauge Number 276} & \multicolumn{2}{|c|}{ Gouge Number 277} \\
\hline Date & Time & $T_{p}(\sec )$ & $H_{3} m(t)$ & $T_{p}(\mathbf{s e c})$ & $H, m(f t)$ \\
\hline 5 Apr 95 & 2240 & 8.5 & $0.21(0.7)$ & & \\
\hline 6 Apr 95 & 0221 & & & 8.5 & $0.15(0.5)$ \\
\hline 6 Apr 95 & 0838 & & & 8.5 & $0.15(0.5)$ \\
\hline 6 Apr 95 & 1455 & & & 8.5 & $0.15(0.5)$ \\
\hline 6 Apr 95 & 2112 & & & 8.5 & $0.15(0.5)$ \\
\hline 7 Apr 95 & 0328 & & & 8.5 & $0.15(0.5)$ \\
\hline 7 Apr 95 & 0945 & & & 8.5 & $0.15(0.5)$ \\
\hline 7 Apr 95 & 1602 & & & 8.5 & $0.15(0.5)$ \\
\hline 7 Apr 95 & 2219 & & & 8.5 & $0.15(0.5)$ \\
\hline 8 Apr 95 & 0436 & & & 8.5 & $0.15(0.5)$ \\
\hline 8 Apr 95 & 1053 & & & 8.5 & $0.15(0.5)$ \\
\hline 8 Apr 95 & 1700 & & & 8.5 & $0.15(0.5)$ \\
\hline 8 Apr 95 & 2326 & & & 8.5 & $0.15(0.5)$ \\
\hline 9 Apr 95 & 0543 & & & 8.5 & $0.15(0.5)$ \\
\hline 9 Apr 95 & 1200 & & & 8.5 & $0.15(0.5)$ \\
\hline 9 Apr 95 & 1817 & & & 8.5 & $0.15(0.5)$ \\
\hline 10 Apr 95 & 0034 & & & 8.5 & $0.15(0.5)$ \\
\hline 10 Apr 95 & 0650 & & & 8.5 & $0.15(0.5)$ \\
\hline 13 Apr 95 & 0105 & 12.8 & $0.09(0.3)$ & & \\
\hline 13 Apr 95 & 0632 & 11.6 & $0.37(1.2)$ & & \\
\hline 13 Apr 95 & 1249 & 10.7 & $0.24(0.8)$ & & \\
\hline 13 Apr 95 & 1905 & 10.7 & $0.27(0.9)$ & & \\
\hline 14 Apr 95 & 0122 & 10.7 & $0.15(0.5)$ & & \\
\hline 14 Apr 95 & 0739 & 9.8 & $0.18(0.6)$ & & \\
\hline 15 Apr 95 & 0846 & 11.6 & $0.18(0.6)$ & & \\
\hline 17 Apr 95 & 2335 & 11.6 & $0.09(0.3)$ & & \\
\hline 18 Apr 95 & 1208 & 10.7 & $0.09(0.3)$ & & \\
\hline
\end{tabular}




\begin{tabular}{|c|c|c|c|}
\hline \multicolumn{4}{|c|}{$\begin{array}{l}\text { Table } 3 \\
\text { Significant Wave Heights and Peak Periods from Hindcast } \\
\text { Data }\end{array}$} \\
\hline \multicolumn{2}{|c|}{ Observation Date and Time } & \multicolumn{2}{|c|}{ WIS Model Results } \\
\hline Date & Time & $T_{p}(\sec )$ & $H_{1} m(f)$ \\
\hline 17 Oct 94 & 1044 & 8 & $0.61(2.0)$ \\
\hline 17 Oct 94 & 1829 & 7 & $0.91(3.0)$ \\
\hline 18 Oct 94 & 1054 & 9 & $1.31(4.3)$ \\
\hline 18 Oct 94 & 1733 & 9 & $1.40(4.6)$ \\
\hline 19 Oct 94 & 1025 & 9 & $0.70(2.3)$ \\
\hline 19 Oct 94 & 1700 & 9 & $0.49(1.6)$ \\
\hline 20 Oct 94 & 1044 & 9 & $0.91(3.0)$ \\
\hline 20 Oct 94 & 1752 & 10 & $1.19(3.9)$ \\
\hline 21 Oct 94 & 1022 & 9 & $1.40(4.6)$ \\
\hline 21 Oct 94 & 1800 & 10 & $1.62(5.3)$ \\
\hline 22 Oct 94 & 1054 & 10 & $1.49(4.9)$ \\
\hline $220 c t 94$ & 1541 & 10 & $1.49(4.9)$ \\
\hline 23 Oct 94 & 1051 & 8 & $0.79(2.6)$ \\
\hline 23 Oct 94 & 1534 & 8 & $0.61(2.0)$ \\
\hline 25 Oct 94 & 1058 & 6 & $0.21(0.7)$ \\
\hline 25 Oct 94 & 1711 & 6 & $0.30(1.0)$ \\
\hline 26 Oct 94 & 1150 & 8 & $0.37(1.2)$ \\
\hline $260 \mathrm{ct} 94$ & 1932 & 8 & $0.49(1.6)$ \\
\hline 28 Oct 94 & 1039 & 8 & 0.49 (1.6) \\
\hline 28 Oct 94 & 1750 & 9 & $0.70(2.3)$ \\
\hline 31 Oct 94 & 1044 & 11 & $2.41(7.9)$ \\
\hline 31 Oct 94 & 1651 & 11 & $2.50(8.2)$ \\
\hline 1 Nov 94 & 1015 & 8 & 1.01 (3.3) \\
\hline 1 Nov 94 & 1730 & 10 & $2.01(6.6)$ \\
\hline 2 Nov 94 & 1039 & 9 & $1.10(3.6)$ \\
\hline 2 Nov 94 & 1814 & 9 & 1.31 (4.3) \\
\hline 3 Nov 94 & 1409 & 13 & $2.59(8.5)$ \\
\hline 3 Nov 94 & 1836 & 14 & $2.32(7.6)$ \\
\hline 4 Nov 94 & 1207 & 12 & $1.40(4.6)$ \\
\hline
\end{tabular}




\begin{tabular}{|c|c|c|c|}
\hline \multicolumn{4}{|c|}{ Table 3 (Continued) } \\
\hline \multicolumn{2}{|c|}{ Observation Date and Time } & \multicolumn{2}{|c|}{ Wis Model Results } \\
\hline Date & Time & $T_{p}$ (sec) & $H_{1}, m(f t)$ \\
\hline 4 Nov 94 & 1726 & 10 & $1.62 \quad(5.3)$ \\
\hline 9 Nov 94 & 1109 & 11 & $2.19 \quad(7.2)$ \\
\hline 10 Nov 94 & 1102 & 11 & $2.50 \quad(8.2)$ \\
\hline 10 Nov 94 & 1558 & 11 & $2.59 \quad(8.5)$ \\
\hline 11 Nov 94 & 0950 & 12 & $4.69(15.4)$ \\
\hline 11 Nov 94 & 1603 & 13 & $5.00(16.4)$ \\
\hline 12 Nov 94 & 1147 & 13 & $3.51(11.5)$ \\
\hline 12 Nov 94 & 1738 & 13 & $2.50 \quad(8.2)$ \\
\hline 13 Nov 94 & 1006 & 10 & $2.01 \quad(6.6)$ \\
\hline 13 Nov 94 & 1800 & 8 & $1.49 \quad(4.9)$ \\
\hline 14 Nov 94 & 0950 & 11 & $2.90 \quad(9.5)$ \\
\hline 14 Nov 94 & 1550 & 12 & $3.99(13.1)$ \\
\hline 15 Nov 94 & 1222 & 13 & $3.81(12.5)$ \\
\hline 15 Nov 94 & 1706 & 12 & $3.29(10.8)$ \\
\hline 16 Nov 94 & 1121 & 10 & $\begin{array}{ll}1.80 & (5.9) \\
\end{array}$ \\
\hline 16 Nov 94 & 1730 & 9 & $2.01 \quad(6.6)$ \\
\hline 17 Nov 94 & 1224 & 10 & 1.62 \\
\hline 17 Nov 94 & 1812 & 7 & $1.10 \quad(3.6)$ \\
\hline 18 Nov 94 & 1013 & 6 & $1.01 \quad(3.3)$ \\
\hline 18 Nov 94 & 1699 & 6 & $\begin{array}{ll}1.10 \quad(3.6) \\
\end{array}$ \\
\hline 19 Nov 94 & 1126 & 10 & $2.01 \quad(6.6)$ \\
\hline 19 Nov 94 & 1644 & 10 & $\begin{array}{ll}2.10 \quad(6.9) \\
\end{array}$ \\
\hline 20 Nov 94 & 1241 & 9 & $\begin{array}{ll}1.62 \quad(5.3) \\
\end{array}$ \\
\hline 20 Nov 94 & 1704 & 9 & $1.40 \quad(4.6)$ \\
\hline 21 Nov 94 & 1015 & 8 & $0.49 \quad(1.6)$ \\
\hline 21 Nov 94 & 1728 & 9 & $0.49 \quad(1.6)$ \\
\hline 22 Nov 94 & 1044 & 8 & $0.37 \quad(1.2)$ \\
\hline 22 Nov 94 & 1735 & 9 & $0.30 \quad(1.0)$ \\
\hline 23 Nov 94 & 1049 & 12 & $1.31 \quad(4.3)$ \\
\hline
\end{tabular}




\begin{tabular}{|c|c|c|c|}
\hline \multicolumn{4}{|c|}{ Table 3 (Concluded) } \\
\hline \multicolumn{2}{|c|}{ Observation Date and Time } & \multicolumn{2}{|c|}{ WIS Model Results } \\
\hline Date & Time & $T_{p}(\sec )$ & $H_{2} \mathbf{m}(t)$ \\
\hline 23 Nov 94 & 1706 & 11 & $0.91 \quad(3.0)$ \\
\hline 24 Nov 94 & 1044 & 8 & $0.37 \quad(1.2)$ \\
\hline 24 Nov 94 & 1548 & 8 & $0.70 \quad(2.3)$ \\
\hline 25 Nov 94 & 1111 & 11 & $2.80 \quad(9.2)$ \\
\hline 25 Nov 94 & 1514 & 12 & $3.69(12.1)$ \\
\hline 26 Nov 94 & 1111 & 15 & $4.79(15.7)$ \\
\hline 26 Nov 94 & 1630 & 15 & $3.90(12.8)$ \\
\hline 27 Nov 94 & 1111 & 10 & $1.49 \quad(4.9)$ \\
\hline 27 Nov 94 & 1618 & 10 & $1.01 \quad$ (3.3) \\
\hline 28 Nov 94 & 1056 & 8 & $0.30 \quad(1.0)$ \\
\hline 28 Nov 94 & 1536 & 8 & $0.21(0.7)$ \\
\hline 29 Nov 94 & 1100 & 7 & $0.09 \quad(0.3)$ \\
\hline 4 Dec 94 & 1106 & 7 & $0.49 \quad(1.6)$ \\
\hline 5 Dec 94 & 1735 & 7 & $0.37 \quad(1.2)$ \\
\hline 6 Dec 94 & 1051 & 8 & $1.19 \quad(3.9)$ \\
\hline 6 Dec 94 & 1630 & 8 & $1.10 \quad(3.6)$ \\
\hline 8 Dec 94 & 1126 & 9 & $1.01 \quad$ (3.3) \\
\hline 8 Dec 94 & 1546 & 9 & $1.10 \quad(3.6)$ \\
\hline 9 Dec 94 & 1030 & 10 & $1.31 \quad(4.3)$ \\
\hline 10 Dec 94 & 1116 & 11 & $3.11(10.2)$ \\
\hline 10 Dec 94 & 1601 & 12 & $3.60(11.8)$ \\
\hline 11 Dec 94 & 1130 & 10 & $1.62 \quad(5.3)$ \\
\hline 11 Dec 94 & 1630 & 10 & $1.49 \quad(4.9)$ \\
\hline 12 Dec 94 & 1130 & 11 & $1.89 \quad(6.2)$ \\
\hline 12 Dec 94 & 1704 & 11 & $1.80 \quad(5.9)$ \\
\hline
\end{tabular}




\section{Table 4 \\ Wave Runup Data Secured with Videotape Analysis}

\begin{tabular}{|c|c|c|c|c|}
\hline \multicolumn{2}{|c|}{ Observation Date and Time } & \multicolumn{2}{|c|}{ Profile 1} & \multirow[b]{2}{*}{ Comments } \\
\hline Date & Time & $T_{p}(\sec )$ & $\begin{array}{l}\text { Runup el } \\
m(\mathrm{ft})\end{array}$ & \\
\hline 17 Oct 94 & 1044 & & & negligible runup \\
\hline 17 Oct 94 & 1829 & & & negligible runup \\
\hline 18 Oct 94 & 1054 & & & negligible runup \\
\hline 18 Oct 94 & 1733 & & & raining, targets not visible \\
\hline 19 Oct 94 & 1025 & 13.5 & $6.77(22.2)$ & \\
\hline 19 Oct 94 & 1700 & 14.6 & $7.11(23.3)$ & \\
\hline 20 Oct 94 & 1044 & & & negligible runup \\
\hline 20 Oct 94 & 1752 & & & negligible runup \\
\hline 21 Oct 94 & 1022 & & & negligible runup \\
\hline 21 Oct 94 & 1800 & & & negligible runup \\
\hline 22 Oct 94 & 1054 & 11.6 & $5.73(18.8)$ & \\
\hline 22 Oct 94 & 1541 & 14.6 & $10.62(34.8)$ & \\
\hline 23 Oct 94 & 1051 & 14.6 & $6.97(22.9)$ & \\
\hline 23 Oct 94 & 1534 & & & foggy, targets not visible \\
\hline 25 Oct 94 & 1058 & & & negligible runup \\
\hline 25 Oct 94 & 1711 & & & negligible runup \\
\hline 26 Oct 94 & 1150 & & & negligible runup \\
\hline 26 Oct 94 & 1932 & & & negligible runup \\
\hline 28 Oct 94 & 1039 & & & foggy, targets not visible \\
\hline 28 Oct 94 & 1750 & & & negligible runup \\
\hline 1 Nov 94 & 1015 & 11.6 & $6.62(22.7)$ & \\
\hline 1 Nov 94 & 1730 & 11.6 & $5.91(19.4)$ & \\
\hline 2 Nov 94 & 1039 & 9.8 & $7.12(23.4)$ & \\
\hline 2 Nov 94 & 1814 & & & raining, targets not visible \\
\hline 3 Nov 94 & 1409 & 12.8 & $12.92(42.4)$ & overtopping \\
\hline 3 Nov 94 & 1836 & & & overtopping, too dark \\
\hline 9 Nov 94 & 1109 & 12.8 & $11.37(37.3)$ & \\
\hline 10 Nov 94 & 1102 & 12.8 & $12.92(42.3)$ & overtopping \\
\hline
\end{tabular}




\begin{tabular}{|c|c|c|c|c|}
\hline \multicolumn{2}{|c|}{ Observation Date and Time } & \multicolumn{2}{|c|}{ Profile 1} & \multirow[b]{2}{*}{ Comments } \\
\hline Date & Time & $T_{p}$ (sec) & $\begin{array}{l}\text { Runup el } \\
\mathrm{m}(\mathrm{t})\end{array}$ & \\
\hline 10 Nov 94 & 1558 & 15.1 & $9.81(32.2)$ & \\
\hline 11 Nov 94 & 0950 & 12.8 & $13.23(43.4)$ & overtopping \\
\hline 11 Nov 94 & 1603 & 18.3 & $13.54(44.4)$ & overtopping \\
\hline 12 Nov 94 & 1147 & 15.1 & $9.63(31.6)$ & \\
\hline 12 Nov 94 & 1738 & 12.8 & $6.68(21.9)$ & \\
\hline 14 Nov 94 & 0950 & 12.8 & $10.59(34.8)$ & \\
\hline 14 Nov 94 & 1550 & 15.1 & $13.82(45.3)$ & overtopping \\
\hline 15 Nov 94 & 1222 & 12.8 & $10.38(34.1)$ & \\
\hline 15 Nov 94 & 1706 & 13.5 & $10.20(33.5)$ & \\
\hline 16 Nov 94 & 1121 & & & foggy, targets not visible \\
\hline 16 Nov 94 & 1730 & 10.2 & $7.18(23.6)$ & \\
\hline 17 Nov 94 & 1224 & & & negligible runup \\
\hline 17 Nov 94 & 1812 & & & negligible runup \\
\hline 18 Nov 94 & 1013 & & & negligible runup \\
\hline 18 Nov 94 & 1699 & & & negligible runup \\
\hline 19 Nov 94 & 1126 & 9.8 & $5.36(17.6)$ & \\
\hline 19 Nov 94 & 1644 & & & negligible runup \\
\hline 20 Nov 94 & 1241 & & & negligible runup \\
\hline 20 Nov 94 & 1704 & & & negligible runup \\
\hline 21 Nov 94 & 1015 & & & negligible runup \\
\hline 21 Nov 94 & 1728 & & & negligible runup \\
\hline 22 Nov 94 & 1044 & & & negligible runup \\
\hline 22 Nov 94 & 1735 & & & negligible runup \\
\hline 23 Nov 94 & 1049 & & & negligible runup \\
\hline
\end{tabular}




\begin{tabular}{|c|c|c|c|c|}
\hline \multicolumn{2}{|c|}{ Observation Date and Time } & \multicolumn{2}{|c|}{ Protile 1} & \multirow[b]{2}{*}{ Comments } \\
\hline Date & Time & $T_{p}(s \theta c)$ & $\begin{array}{l}\text { Runup of } \\
\mathrm{m}(\mathrm{tt})\end{array}$ & \\
\hline 23 Nov 94 & 1706 & 11.6 & $2.73(24.5)$ & \\
\hline 24 Nov 94 & 1044 & & & $\begin{array}{l}\text { too dark, targets not } \\
\text { visible }\end{array}$ \\
\hline 24 Nov 94 & 1548 & 9.8 & $5.07(16.6)$ & \\
\hline 25 Nov 94 & 1111 & 15.1 & $13.05(43.0)$ & overtopping \\
\hline 25 Nov 94 & 1514 & 15.1 & $13.42(44.0)$ & overtopping \\
\hline 26 Nov 94 & 1111 & 12.8 & $9.26(30.4)$ & \\
\hline 26 Nov 94 & 1630 & 12.8 & $5.40(17.7)$ & \\
\hline 27 Nov 94 & 1111 & 9.8 & $3.26(10.7)$ & \\
\hline 27 Nov 94 & 1618 & 9.7 & $3.69(12.1)$ & \\
\hline 28 Nov 94 & 1056 & & & negligible runup \\
\hline 28 Nov 94 & 1536 & & & negligible runup \\
\hline 29 Nov 94 & 1100 & & & negligible runup \\
\hline 4 Dec 94 & 1106 & & & negligible runup \\
\hline 5 Dec 94 & 1735 & & & negligible runup \\
\hline 6 Dec 94 & 1051 & & & negligible runup \\
\hline 6 Dec 94 & 1630 & & & negligible runup \\
\hline 8 Dec 94 & 1126 & 10.9 & $5.71(18.7)$ & \\
\hline 8 Dec 94 & 1546 & 10.9 & $5.32(17.5)$ & \\
\hline 9 Dec 94 & 1030 & & & negligible runup \\
\hline 10 Dec 94 & 1116 & 12.8 & $9.76(32.0)$ & \\
\hline 10 Dec 94 & 1601 & 12.8 & $7.67(25.2)$ & \\
\hline 11 Dec 94 & 1130 & & & negligible runup \\
\hline 11 Dec 94 & 1630 & 19.7 & $6.45(21.2)$ & \\
\hline 12 Dec 94 & 1704 & 14.6 & $6.30(20.7)$ & \\
\hline
\end{tabular}




\section{Table 5}

Broken Armor Stone Inventory as of June 1996

\begin{tabular}{|c|c|c|c|c|c|c|c|}
\hline \multirow[b]{2}{*}{ Station } & \multirow[b]{2}{*}{ Stone No. } & \multicolumn{2}{|c|}{$\begin{array}{l}\text { Distance from Baseline } \\
\qquad \mathrm{m}(\mathrm{t})\end{array}$} & \multirow[b]{2}{*}{ Station } & \multirow[b]{2}{*}{ Stone No. } & \multicolumn{2}{|c|}{$\begin{array}{l}\text { Distance from Baseline } \\
\qquad m(\mathrm{ft})\end{array}$} \\
\hline & & Sea Side & Harbor Side & & & Sea Side & Harbor Side \\
\hline $7+56$ & 1 & & $3.1(10)$ & $8+83$ & 30 & & $6.1(20)$ \\
\hline $7+64$ & 2 & & $3.1(10)$ & $8+84$ & 31 & & $3.1(10)$ \\
\hline $7+68$ & 3 & 4.3 (14) & & $8+86$ & 32 & & $4.6(15)$ \\
\hline $7+82$ & 4 & & $8.5(28)$ & $8+97$ & 33 & & $2.4(8)$ \\
\hline $7+90$ & 5 & & $8.8(29)$ & $9+03$ & 34 & $13.7(45)$ & \\
\hline $7+91$ & 6 & & $1.5 \quad(5)$ & $9+07$ & 35 & 11.0 (36) & \\
\hline $7+97$ & 7 & & $9.1(30)$ & $9+07$ & 36 & 7.9 (26) & \\
\hline $7+99$ & 8 & & $2.4 \quad(8)$ & $9+10$ & 37 & & 7.9 (26) \\
\hline $7+99$ & 9 & & $4.6(15)$ & $9+12$ & 38 & $0.3 \quad$ (1) & \\
\hline $8+10$ & 10 & 4.3 (14) & & $9+13$ & 39 & $13.7(45)$ & \\
\hline $8+10$ & 11 & $5.8 \quad(19)$ & & $9+16$ & 40 & $14.6(48)$ & \\
\hline $8+14$ & 12 & & $0.3 \quad(1)$ & $9+22$ & 41 & $0.3 \quad$ (1) & \\
\hline $8+15$ & 13 & & $8.8(29)$ & $9+22$ & 42 & & $7.0(23)$ \\
\hline $8+27$ & 14 & & $8.8(29)$ & $9+28$ & 43 & & $7.6(25)$ \\
\hline $8+29$ & 15 & $13.4 \quad(44)$ & & $9+34$ & 44 & $4.3(14)$ & \\
\hline $8+35$ & 16 & $7.0 \quad(23)$ & & $9+37$ & 45 & & $2.1(7)$ \\
\hline $8+44$ & 17 & & $1.5 \quad(5)$ & $9+44$ & 46 & & 2.7 (9) \\
\hline $8+44$ & 18 & & $8.2(27)$ & $9+44$ & 47 & & $3.1(10)$ \\
\hline $8+57$ & 19 & 14.9 (49) & & $9+53$ & 48 & $2.1 \quad(7)$ & \\
\hline $8+57$ & 20 & & $3.1(10)$ & $9+53$ & 49 & $5.2(17)$ & \\
\hline $8+60$ & 21 & & $7.3(24)$ & $9+55$ & 50 & 3.4 (11) & \\
\hline $8+63$ & 22 & 9.5 (31) & & $9+58$ & 51 & $6.4(21)$ & \\
\hline $8+63$ & 23 & $11.3 \quad(37)$ & & $9+58$ & 52 & & $4.9(16)$ \\
\hline $8+70$ & 24 & & 7.9 (26) & $9+59$ & 53 & 4.0 (13) & \\
\hline $8+71$ & 25 & $10.1 \quad(33)$ & & $9+61$ & 54 & $0.3 \quad$ (1) & \\
\hline $8+72$ & 26 & & $1.8 \quad(6)$ & $9+68$ & 55 & & $5.8(19)$ \\
\hline $8+73$ & 27 & & $12.2(40)$ & $9+73$ & 56 & $3.1(10)$ & \\
\hline $8+77$ & 28 & $10.4 \quad(34)$ & & $9+73$ & 57 & 10.7 (35) & \\
\hline $8+79$ & 29 & & $1.8 \quad(6)$ & $9+74$ & 58 & & $2.4(8)$ \\
\hline
\end{tabular}




\begin{tabular}{|c|c|c|c|c|c|c|c|}
\hline \multirow[b]{2}{*}{ Station } & \multirow[b]{2}{*}{ Stone No. } & \multicolumn{2}{|c|}{$\begin{array}{c}\text { Distance from Baseline } \\
\mathbf{m}(\mathrm{ft})\end{array}$} & \multirow[b]{2}{*}{ Station } & \multirow[b]{2}{*}{ Stone No. } & \multicolumn{2}{|c|}{$\begin{array}{c}\text { Distance from Baseline } \\
\mathrm{m}(\mathrm{ft})\end{array}$} \\
\hline & & Sea Side & Harbor Side & & & Sea Side & Harbor Side \\
\hline $9+79$ & 59 & & 5.8 (19) & $11+44$ & 89 & 5.5 (18) & \\
\hline $9+81$ & 60 & 4.3 (14) & & $11+46$ & 90 & $12.2(40)$ & \\
\hline $9+81$ & 61 & $7.0 \quad(23)$ & & $11+78$ & 91 & & $7.9(26)$ \\
\hline $9+90$ & 62 & $11.3 \quad(37)$ & & $11+78$ & 92 & & $4.6(15)$ \\
\hline $9+90$ & 63 & $14.6 \quad(48)$ & & $11+83$ & 93 & 13.1 (43) & \\
\hline $9+95$ & 64 & $11.3 \quad(37)$ & & $11+83$ & 94 & $9.1(30)$ & \\
\hline $9+98$ & 65 & & 9.8 (32) & $11+87$ & 95 & $1.2 \quad(4)$ & \\
\hline $10+08$ & 66 & $0.3 \quad$ (1) & & $11+94$ & 96 & $12.2(40)$ & \\
\hline $10+08$ & 67 & 6.7 (22) & & $11+99$ & 97 & $7.0(23)$ & \\
\hline $10+12$ & 68 & & $1.8 \quad(6)$ & $12+\infty$ & 98 & $12.2(40)$ & \\
\hline $10+21$ & 69 & $7.3 \quad(24)$ & & $12+06$ & 99 & & $4.6(15)$ \\
\hline $10+21$ & 70 & $7.3 \quad(24)$ & & $12+13$ & 100 & $6.4(21)$ & \\
\hline $10+21$ & 71 & & $8.5(28)$ & $12+13$ & 101 & $0.9 \quad$ (3) & \\
\hline $10+23$ & 72 & & $7.0(23)$ & $12+15$ & 102 & $3.1(10)$ & \\
\hline $10+23$ & 73 & $9.8 \quad(32)$ & & $12+26$ & 103 & & $3.7(12)$ \\
\hline $10+33$ & 74 & 3.7 (12) & & $12+31$ & 104 & & $6.7(22)$ \\
\hline $10+38$ & 75 & 8.2 (27) & & $12+32$ & 105 & $12.2(40)$ & \\
\hline $10+71$ & 76 & $12.5(41)$ & & $12+35$ & 106 & 3.4 (11) & \\
\hline $10+76$ & $\pi$ & 3.7 (12) & & $12+43$ & 107 & $7.3(24)$ & \\
\hline $10+78$ & 78 & $1.2 \quad$ (4) & & $12+44$ & 108 & 13.1 (43) & \\
\hline $10+88$ & 79 & & $1.5 \quad(5)$ & $12+44$ & 109 & $11.3(37)$ & \\
\hline $10+90$ & 80 & 6.4 (21) & & $12+46$ & 110 & $11.6(38)$ & \\
\hline $10+94$ & 81 & & $2.7 \quad(9)$ & $12+49$ & 111 & $12.2(40)$ & \\
\hline $11+03$ & 82 & 6.7 (22) & & $12+54$ & 112 & & $1.8(6)$ \\
\hline $11+06$ & 83 & & 3.4 (11) & $12+55$ & 113 & & $1.8(6)$ \\
\hline $11+27$ & 84 & $14.6 \quad(48)$ & & $12+62$ & 114 & & $3.7(12)$ \\
\hline $11+31$ & 85 & $4.9 \quad(16)$ & & $12+70$ & 115 & $3.1(10)$ & \\
\hline $11+32$ & 86 & & $9.8(32)$ & $12+72$ & 116 & $11.3(37)$ & \\
\hline $11+40$ & 87 & & $9.8(32)$ & $12+77$ & 117 & 4.9 (16) & \\
\hline $11+44$ & 88 & $9.1 \quad(30)$ & & $12+85$ & 118 & & $3.7(12)$ \\
\hline
\end{tabular}




\begin{tabular}{|c|c|c|c|c|c|c|c|}
\hline \multirow[b]{2}{*}{ Station } & \multirow[b]{2}{*}{ Stone No. } & \multicolumn{2}{|c|}{$\begin{array}{l}\text { Distance from Baseline } \\
\text { m ( }(t)\end{array}$} & \multirow[b]{2}{*}{ Station } & \multirow[b]{2}{*}{ Stone No. } & \multicolumn{2}{|c|}{$\begin{array}{l}\text { Distance from Baseline } \\
\qquad \mathrm{m}(\mathrm{ft})\end{array}$} \\
\hline & & Sea Side & Harbor Side & & & Sea Side & Harbor Side \\
\hline $12+87$ & 119 & 7.9 (26) & & $14+35$ & 149 & & $4.6(15)$ \\
\hline $12+96$ & 120 & $16.2(53)$ & & $14+42$ & 150 & $9.1(30)$ & \\
\hline $13+03$ & 121 & & $1.5 \quad(5)$ & $14+43$ & 151 & & $4.3(14)$ \\
\hline $13+04$ & 122 & $9.1 \quad(30)$ & & $14+54$ & 152 & 3.7 (12) & \\
\hline $13+05$ & 123 & & 5.5 (18) & $14+62$ & 153 & $2.4 \quad(8)$ & \\
\hline $13+10$ & 124 & & 10.7 (35) & $14+70$ & 154 & & $6.1(20)$ \\
\hline $13+10$ & 125 & $5.2(17)$ & & $14+74$ & 155 & 3.7 (12) & \\
\hline $13+17$ & 126 & $0.3 \quad$ (1) & & $14+75$ & 156 & & $7.0(23)$ \\
\hline $13+21$ & 127 & & $7.6(25)$ & $14+80$ & 157 & $7.6(25)$ & \\
\hline $13+36$ & 128 & & $1.5 \quad(5)$ & $14+81$ & 158 & $1.5 \quad(5)$ & \\
\hline $13+38$ & 129 & 5.5 (18) & & $14+82$ & 159 & & $6.7(22)$ \\
\hline $13+40$ & 130 & 10.4 (34) & & $14+91$ & 160 & $6.4(21)$ & \\
\hline $13+43$ & 131 & 5.2 (17) & & $14+91$ & 161 & 4.3 (14) & \\
\hline $13+43$ & 132 & $7.0 \quad(23)$ & & $15+\infty$ & 162 & $6.1(20)$ & \\
\hline $13+50$ & 133 & & $6.1(20)$ & $15+04$ & 163 & $10.7(35)$ & \\
\hline $13+62$ & 134 & & 2.7 (9) & $15+05$ & 164 & $7.3(24)$ & \\
\hline $13+62$ & 135 & & 4.0 (13) & $15+05$ & 165 & $16.2(53)$ & \\
\hline $13+66$ & 136 & 10.7 (35) & & $15+12$ & 166 & & $8.5(28)$ \\
\hline $13+72$ & 137 & $4.6 \quad(15)$ & & $15+12$ & 167 & & 6.7 (22) \\
\hline $13+74$ & 138 & 3.7 (12) & & $15+20$ & 168 & $3.1(10)$ & \\
\hline $13+76$ & 139 & 12.8 (42) & & $15+23$ & 169 & & $8.2(27)$ \\
\hline $13+80$ & 140 & $5.2(17)$ & & $15+23$ & 170 & & $5.2(17)$ \\
\hline $13+83$ & 141 & $5.8 \quad(19)$ & & $15+27$ & 171 & & $8.2(27)$ \\
\hline $13+89$ & 142 & 9.1 (30) & & $15+31$ & 172 & 11.6 (38) & \\
\hline $13+92$ & 143 & 13.7 (45) & & $15+34$ & 173 & $9.1(30)$ & \\
\hline $14+04$ & 144 & $0.9 \quad$ (3) & & $15+45$ & 174 & & $11.3(37)$ \\
\hline $14+04$ & 145 & & $3.1(10)$ & $15+48$ & 175 & & $7.3(24)$ \\
\hline $14+23$ & 146 & $6.1 \quad(22)$ & & $15+50$ & 176 & & $9.8(32)$ \\
\hline $14+25$ & 147 & $12.8 \quad(42)$ & & $15+53$ & 177 & $0.6 \quad$ (2) & \\
\hline $14+35$ & 148 & 11.9 & & $15+57$ & 178 & $2.4 \quad(8)$ & \\
\hline
\end{tabular}




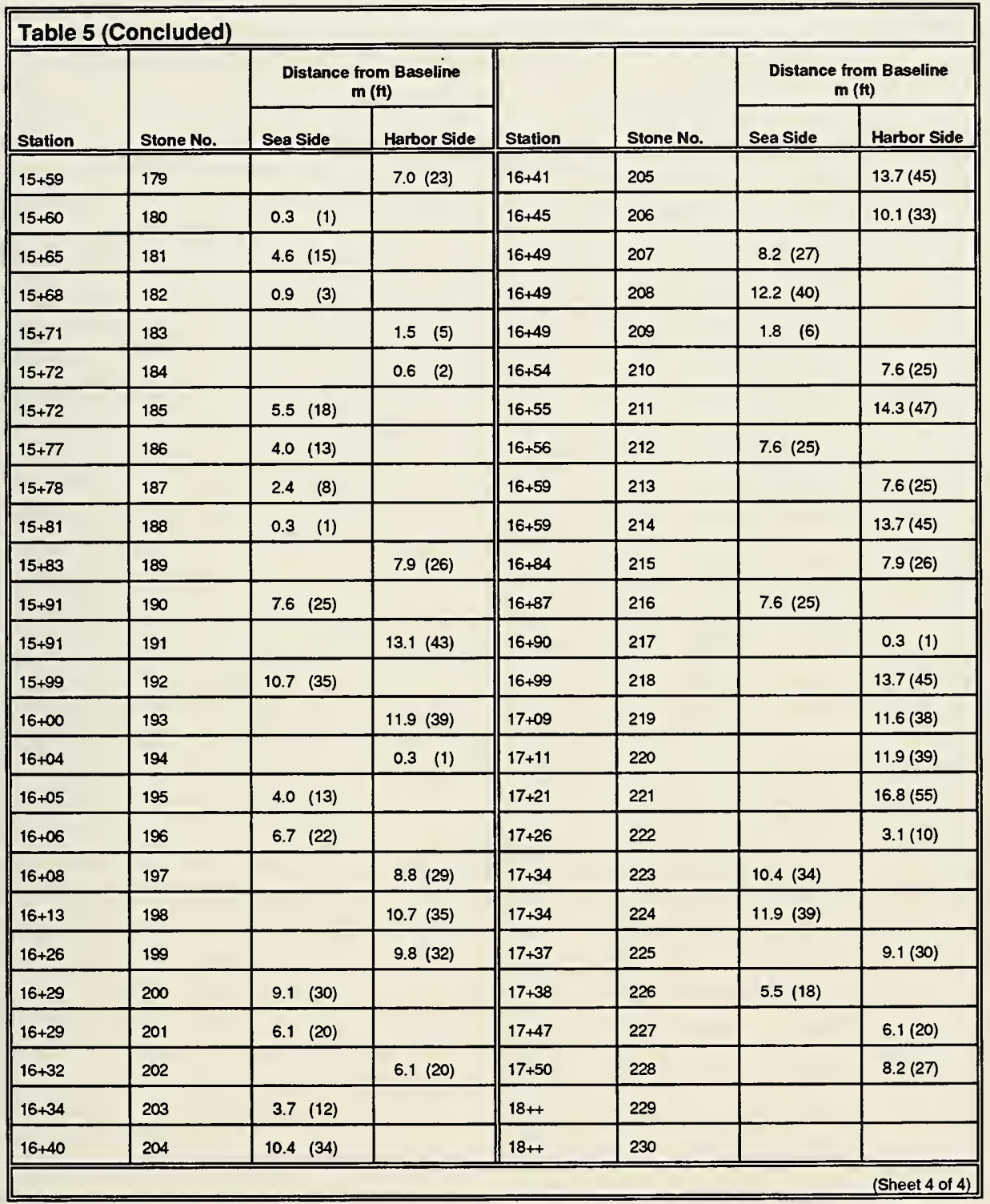




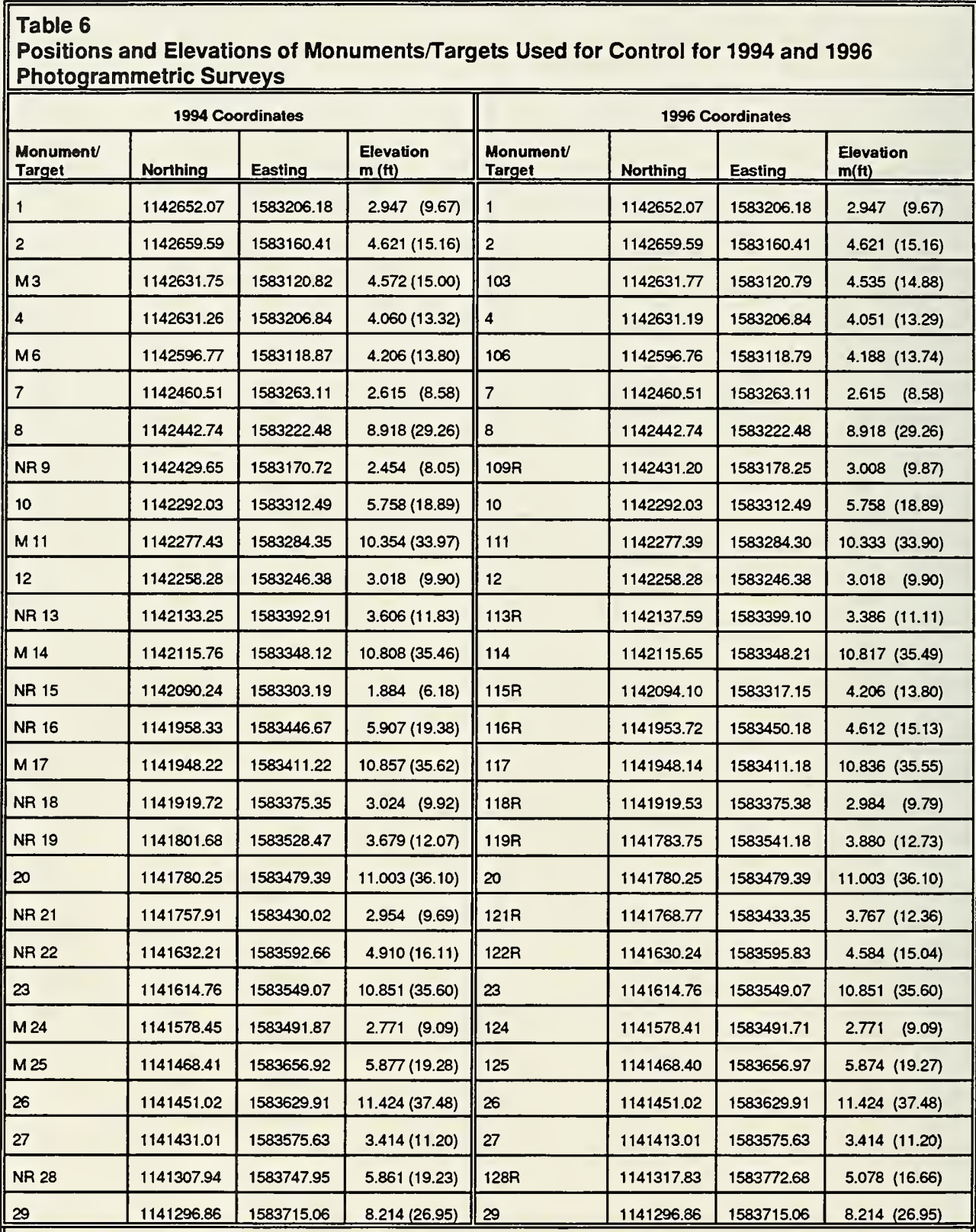




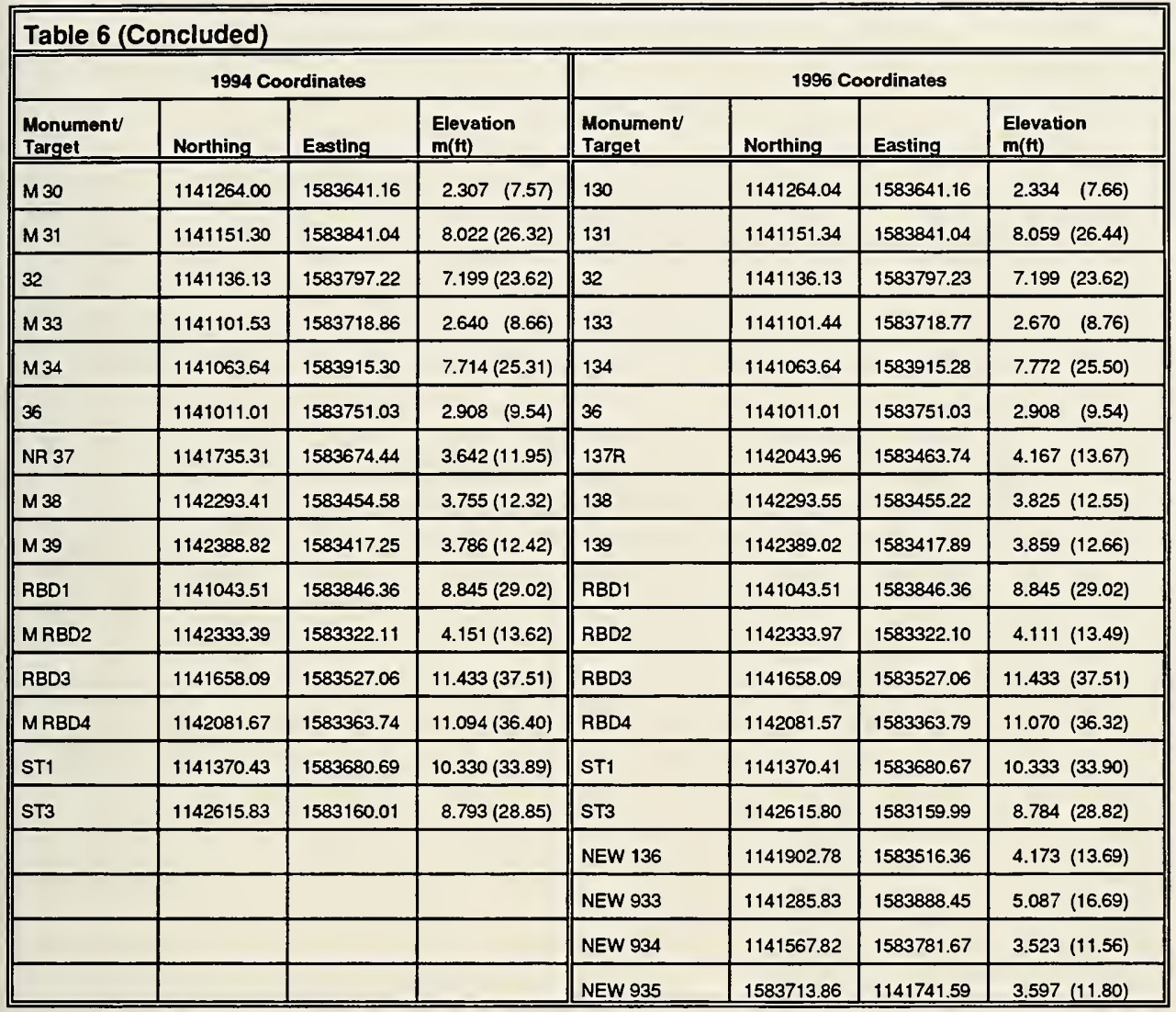





\section{Appendix A Breakwater Topography, 1996}

This appendix presents contour maps of the St. Paul Harbor breakwater extension as a result of the photogrammetric analysis conducted in May 1996. Topography was developed using the digital terrain model (DTM) as stated in the main text of this report. The breakwater topography is shown on a $0.3-\mathrm{m}(1.0-\mathrm{ft})$ contour interval. Elevations shown are in feet referred to mean lower low water (mllw) datum. Station numbering on the contour maps is a southerly to northerly direction. The scale of the maps is $2.54 \mathrm{~cm}=6.1 \mathrm{~m}(1 \mathrm{in} .=20 \mathrm{ft})$. 


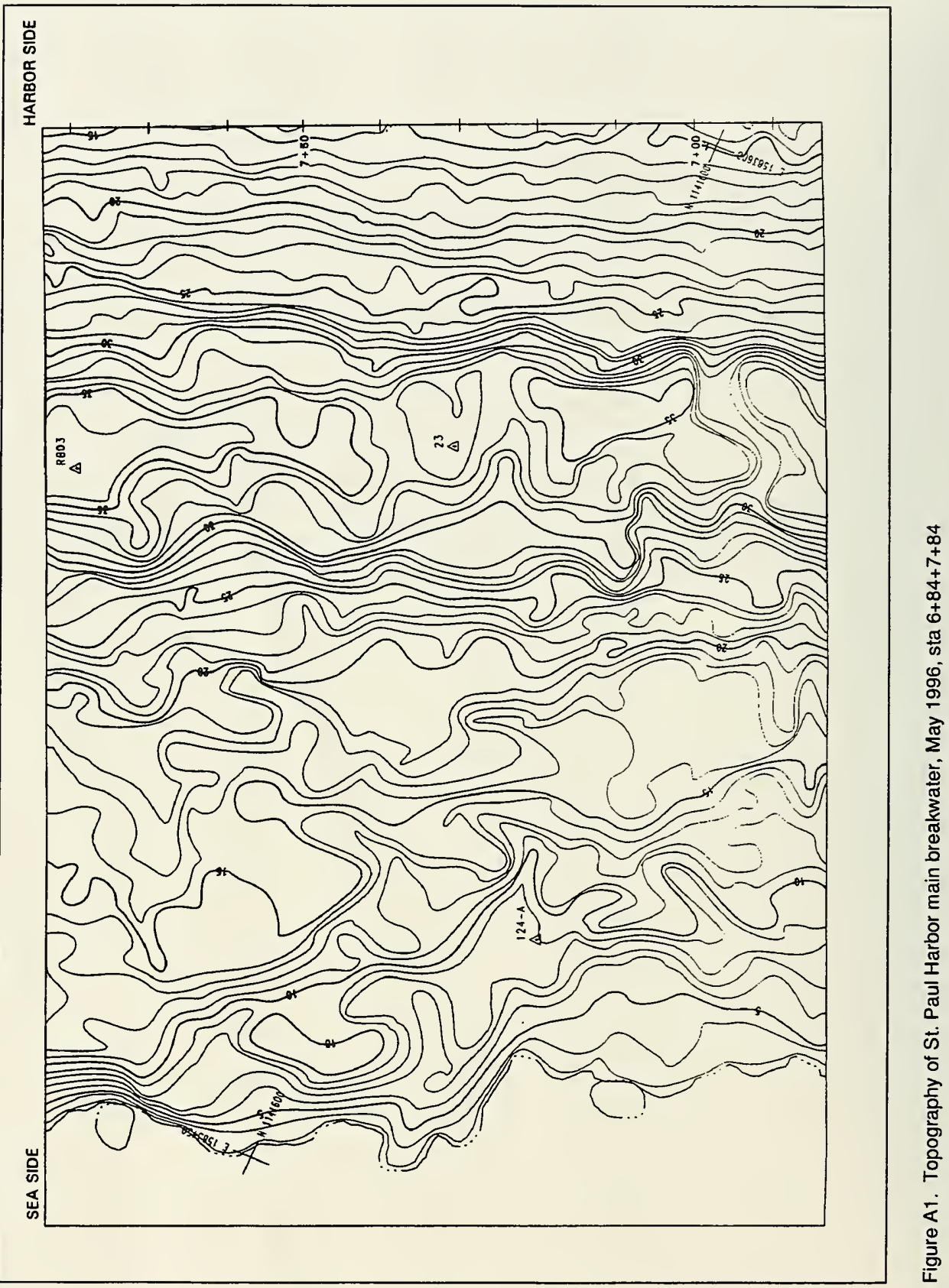




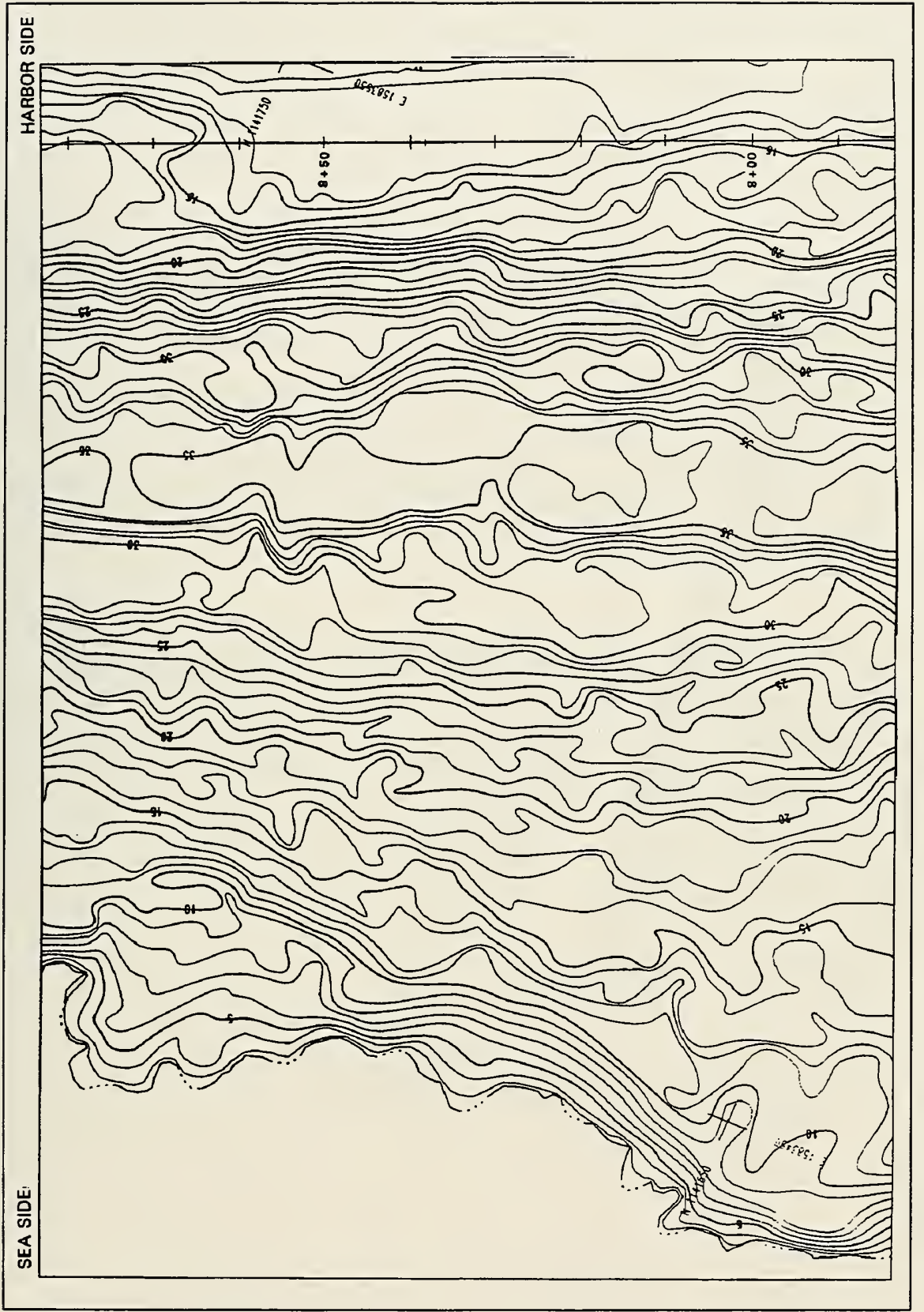

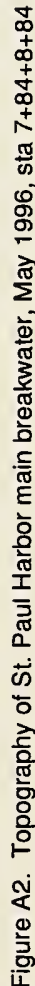




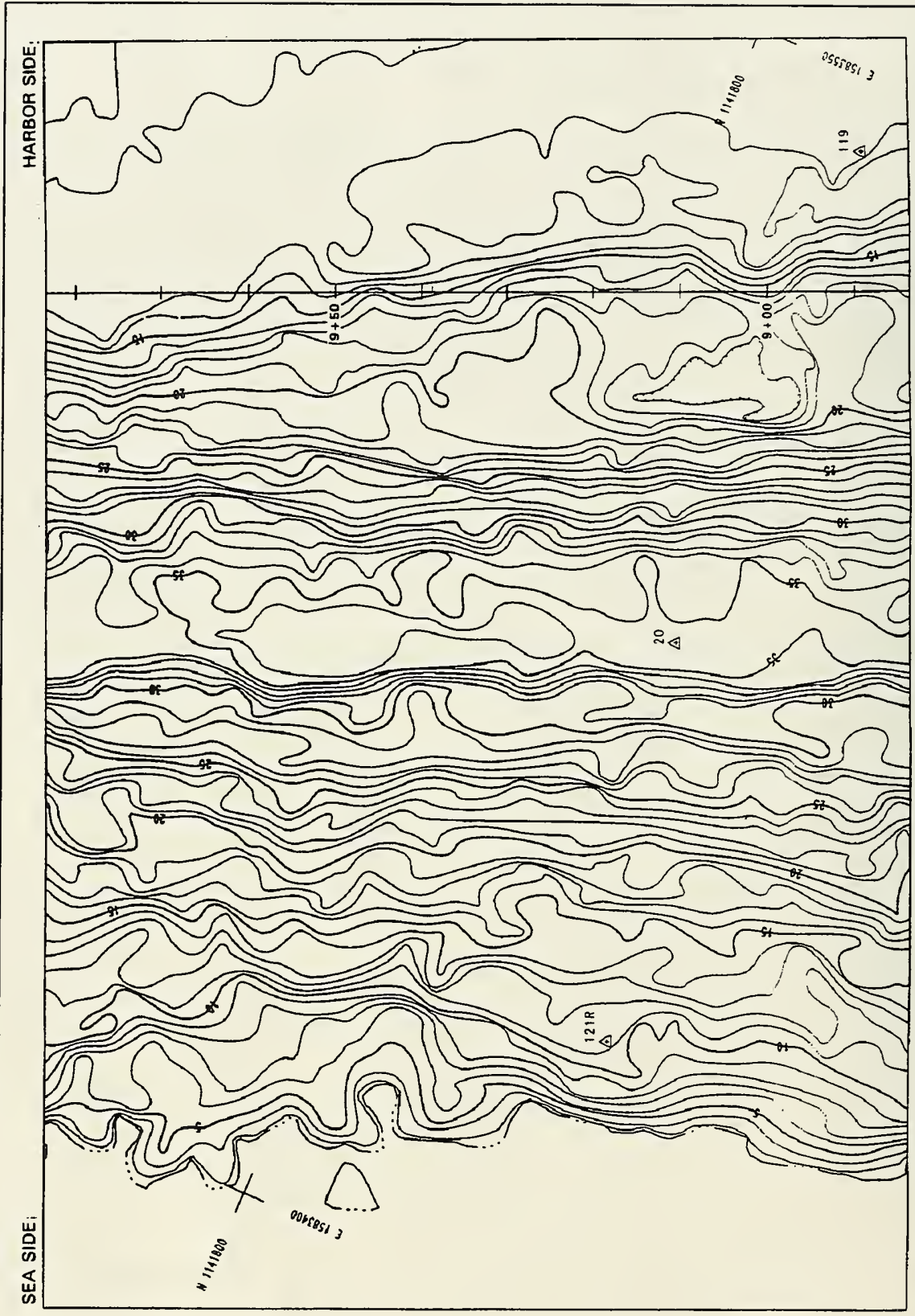

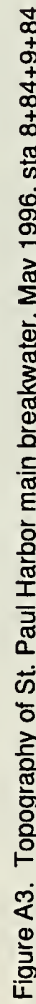




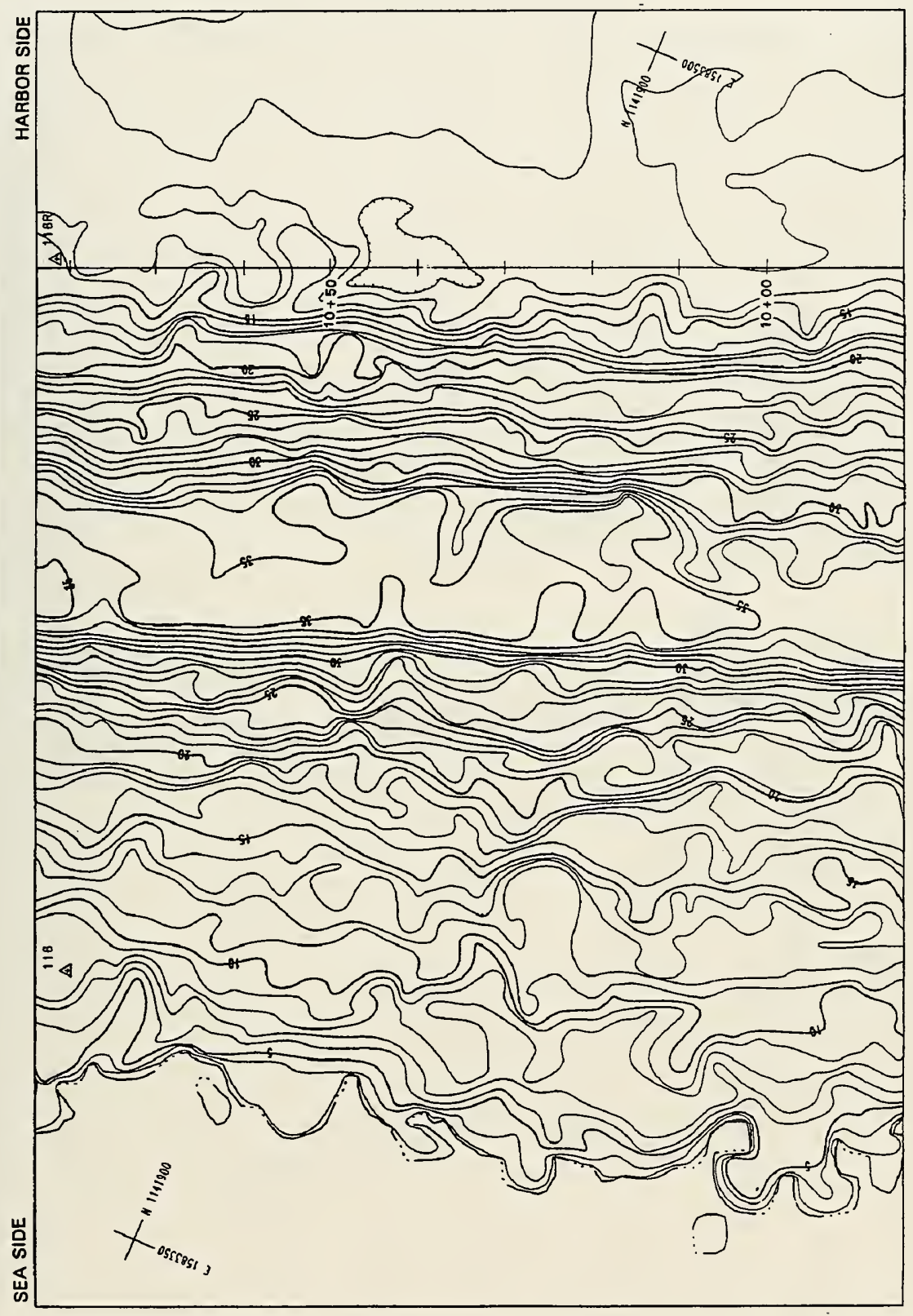

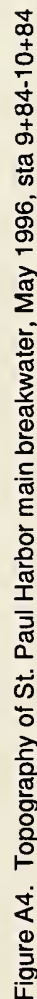




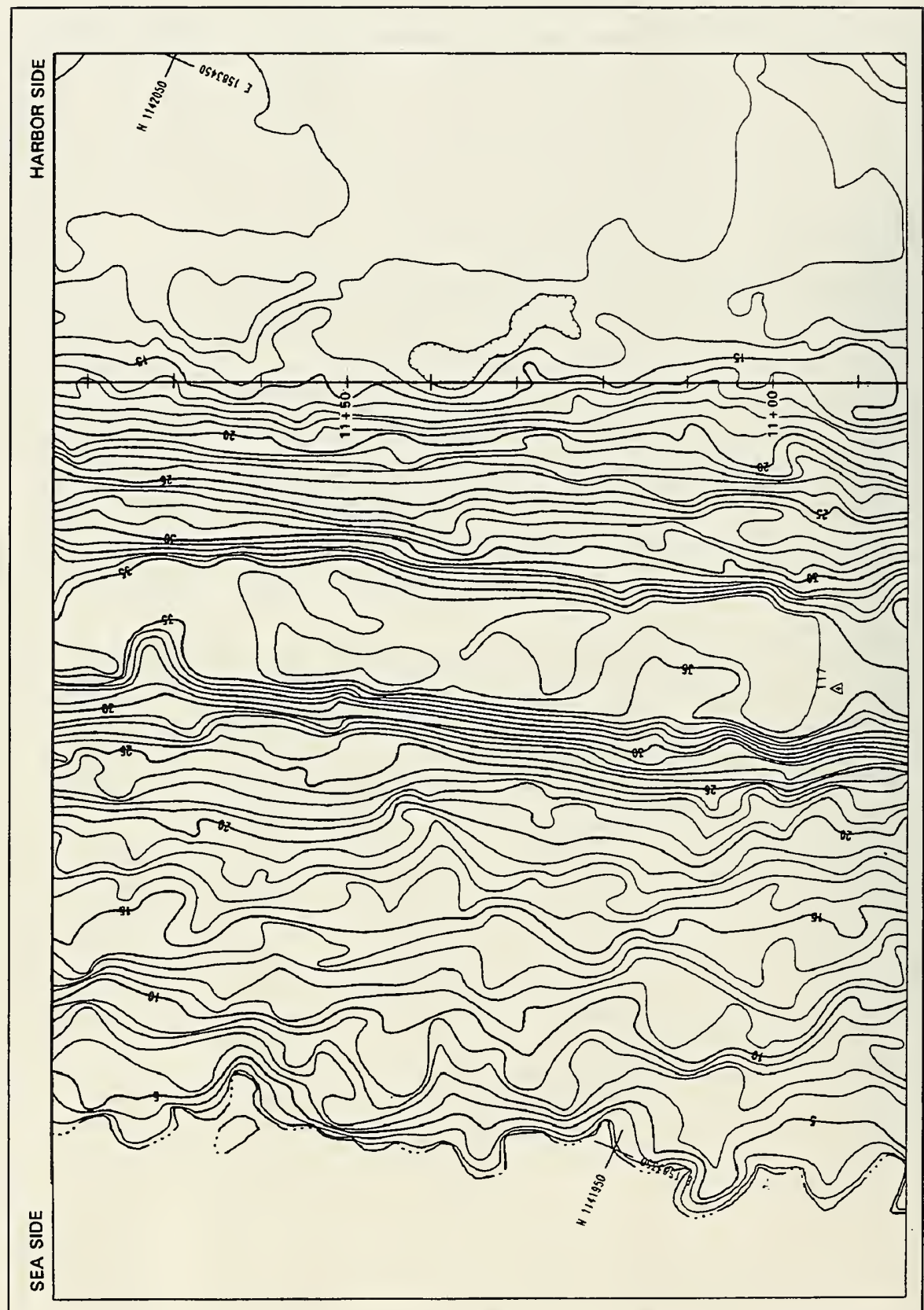

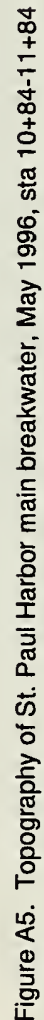




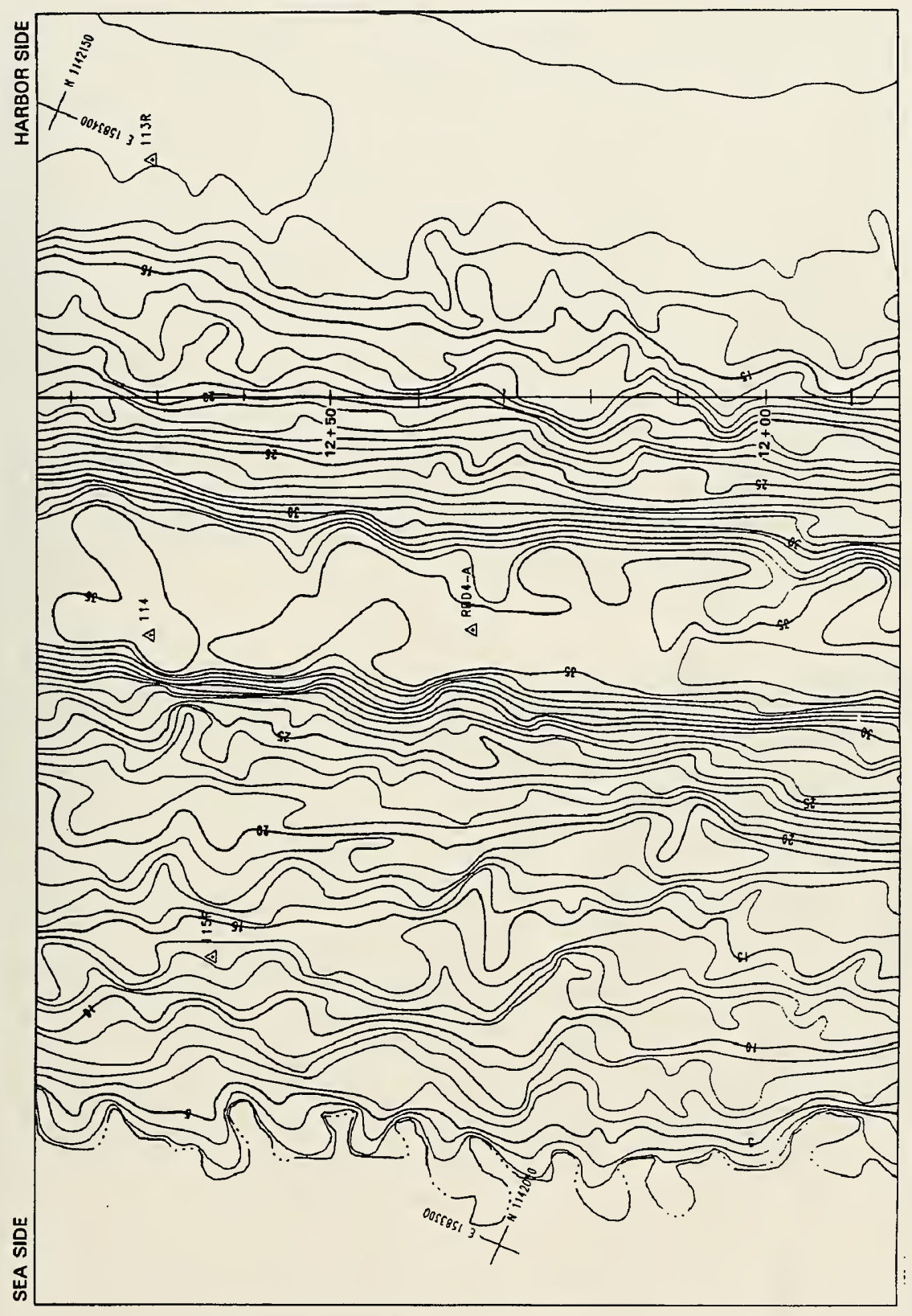

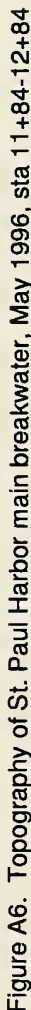




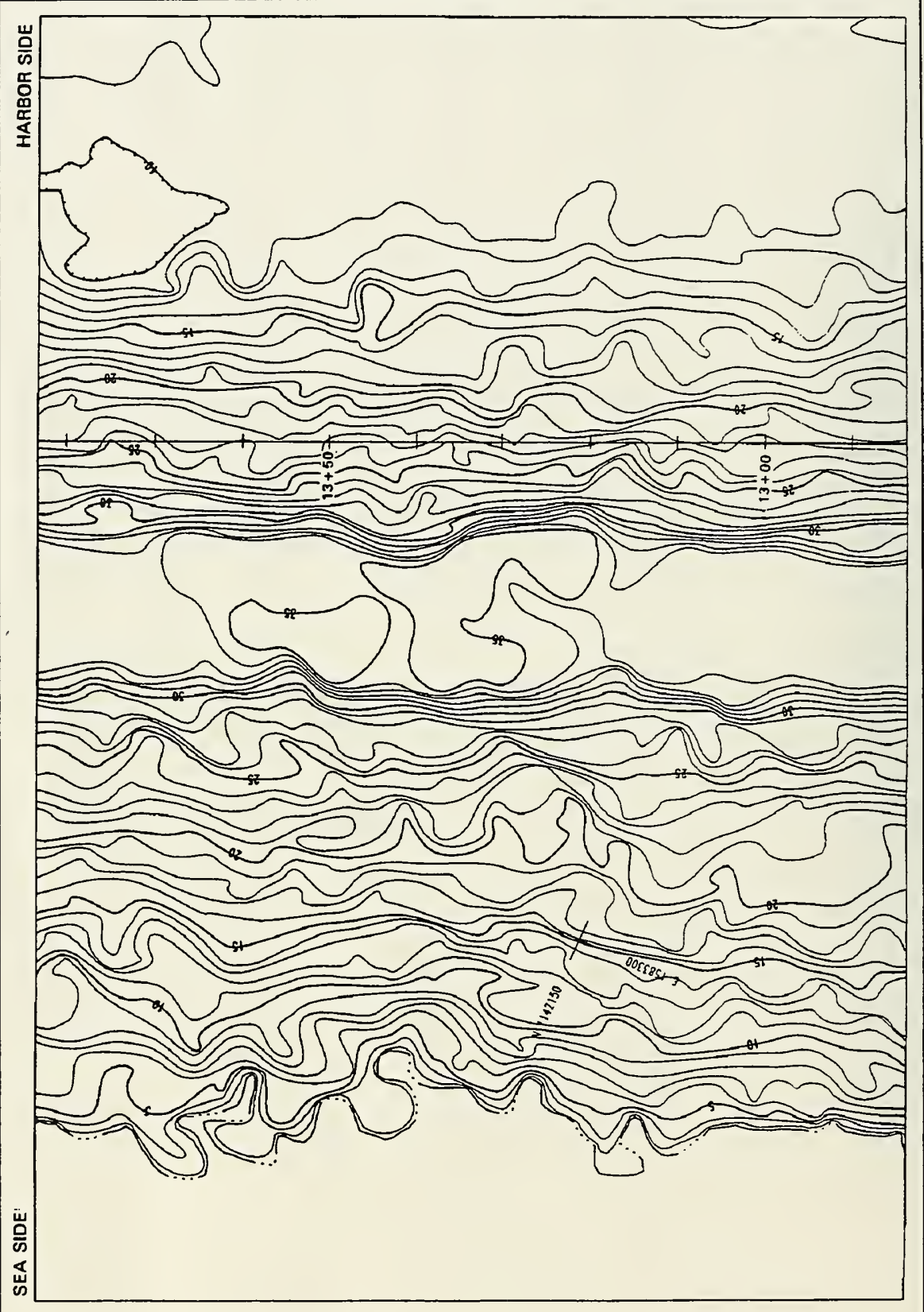

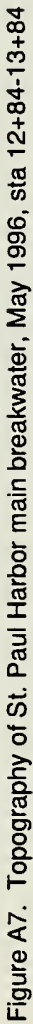




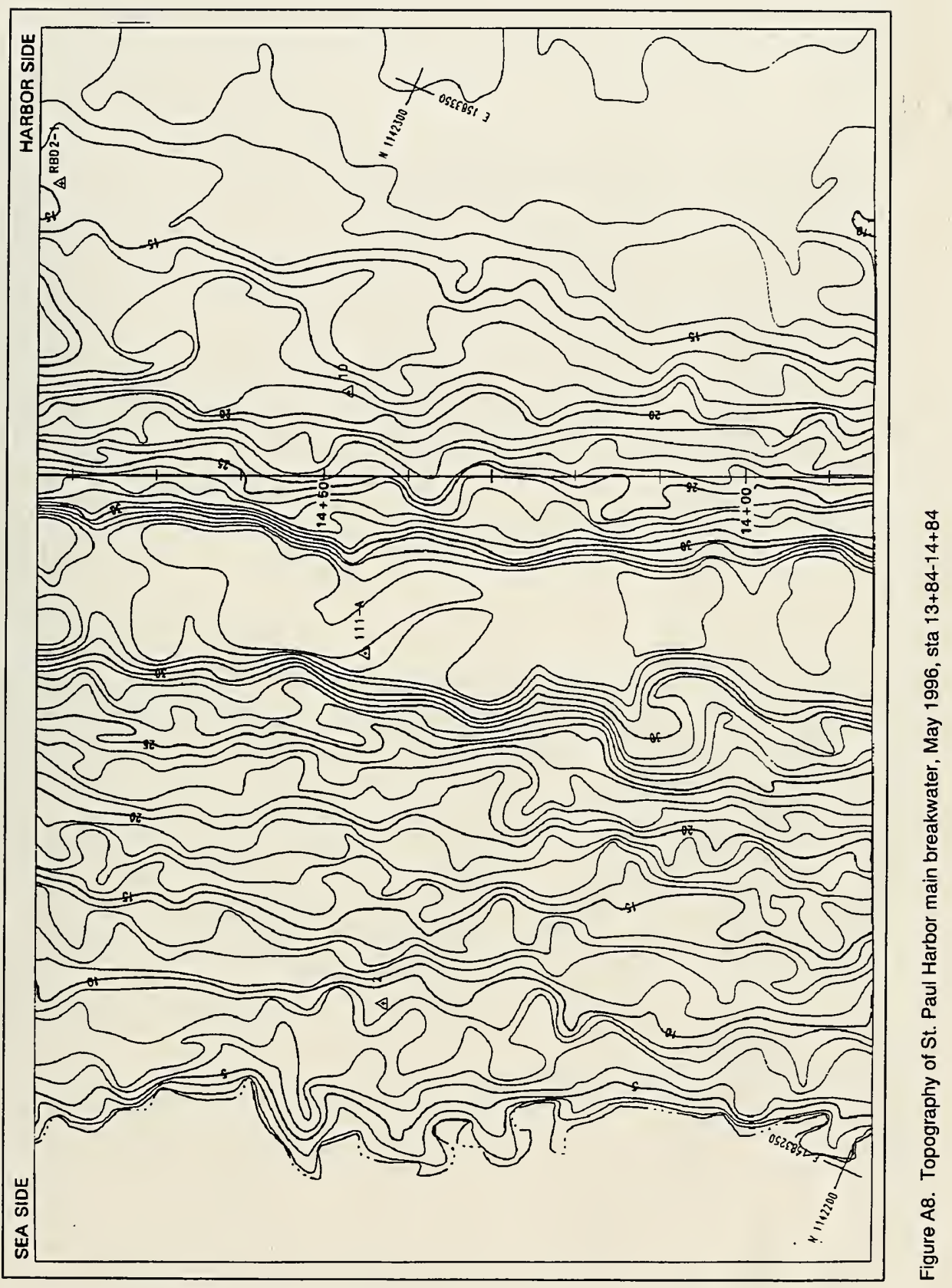




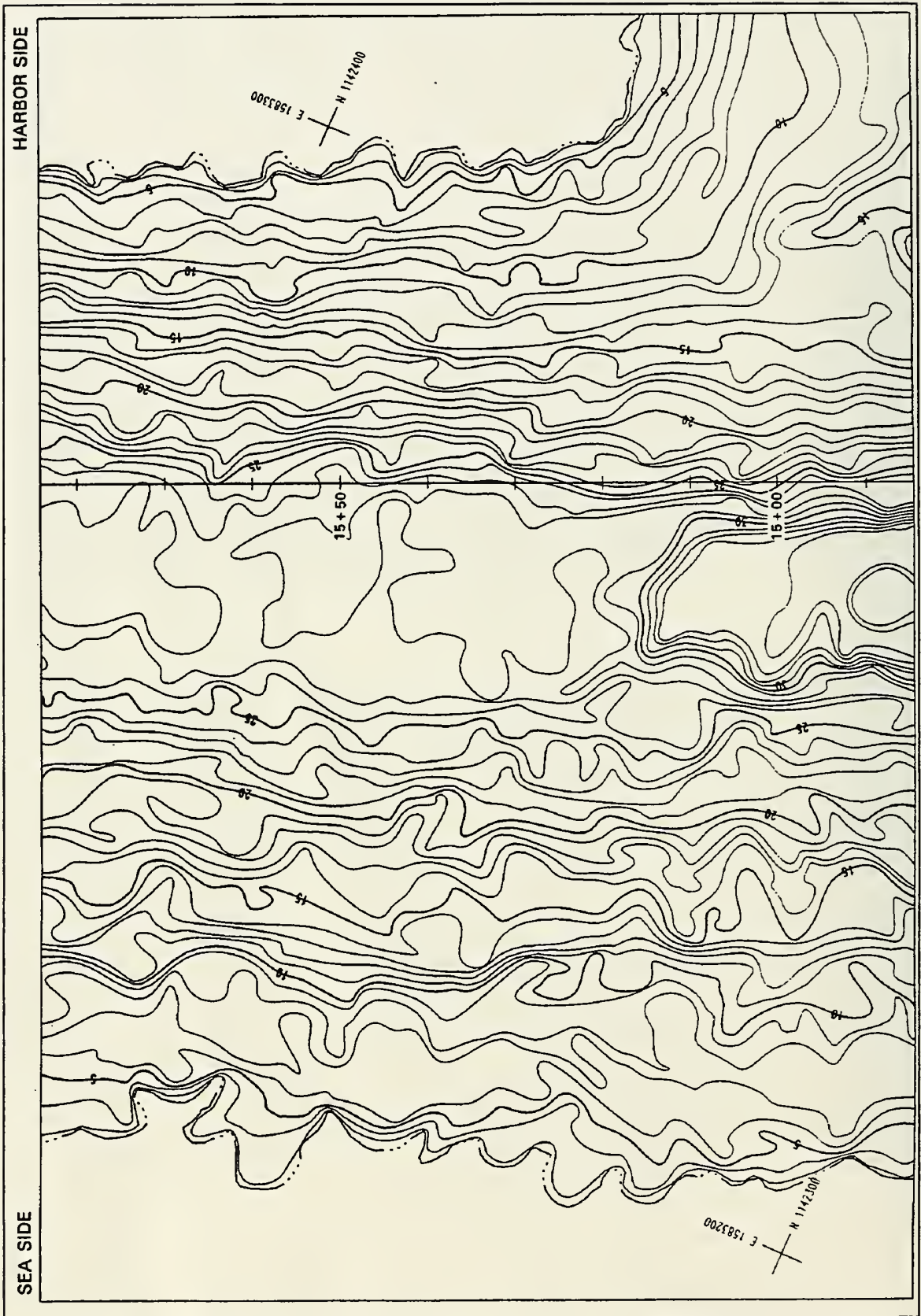

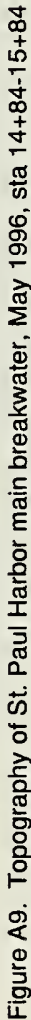




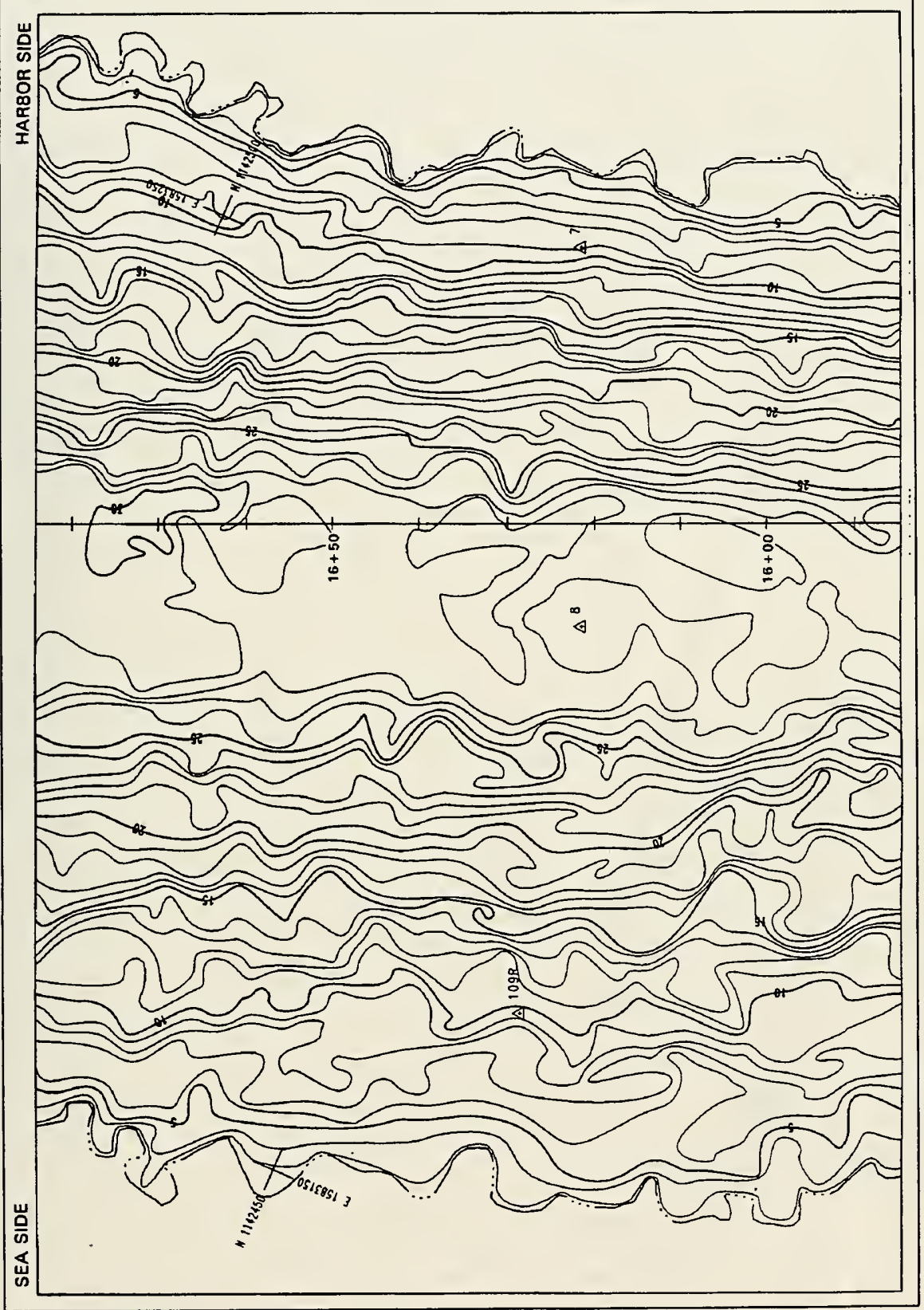

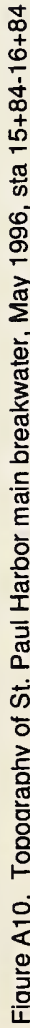




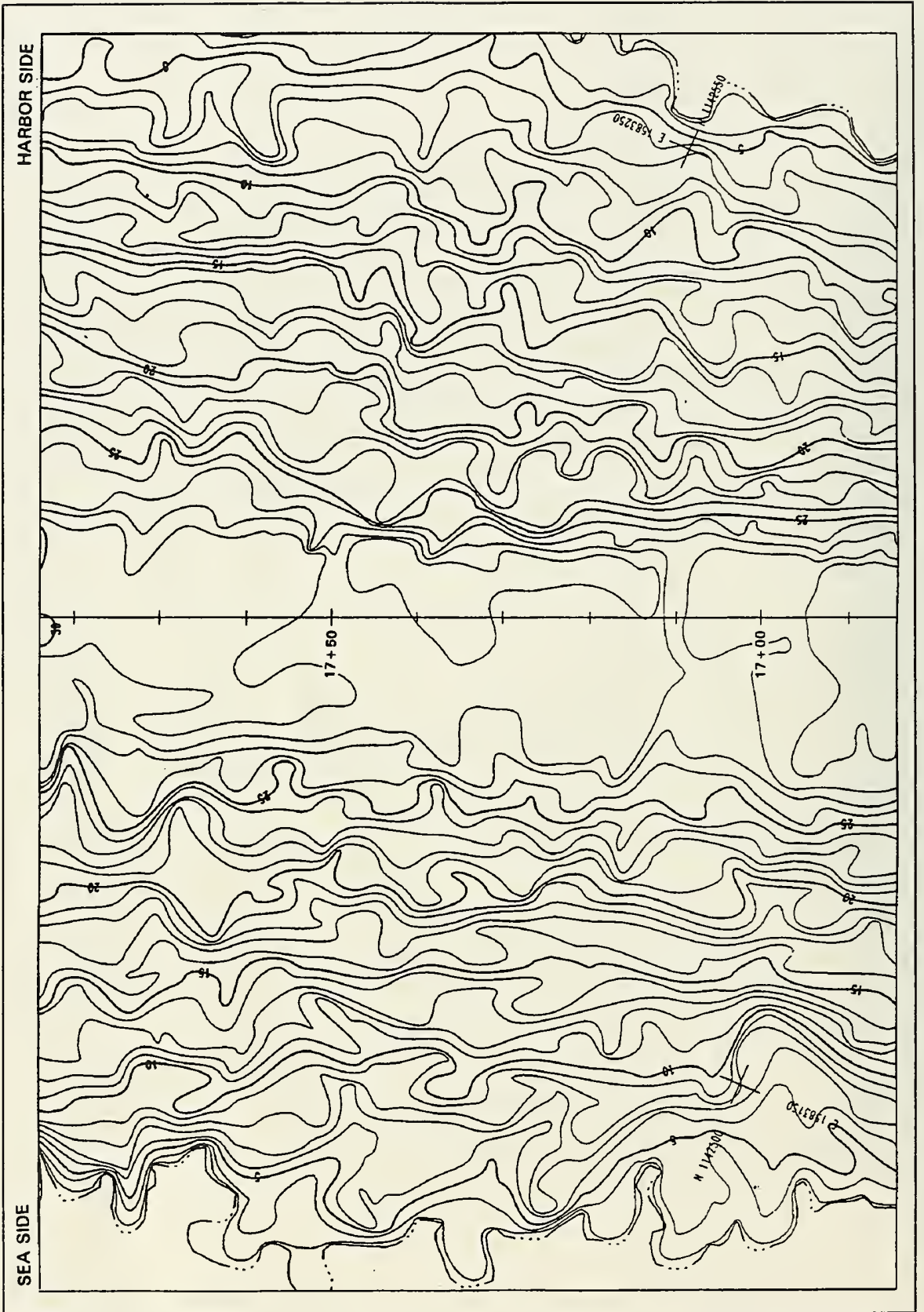

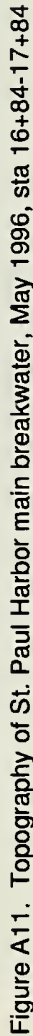




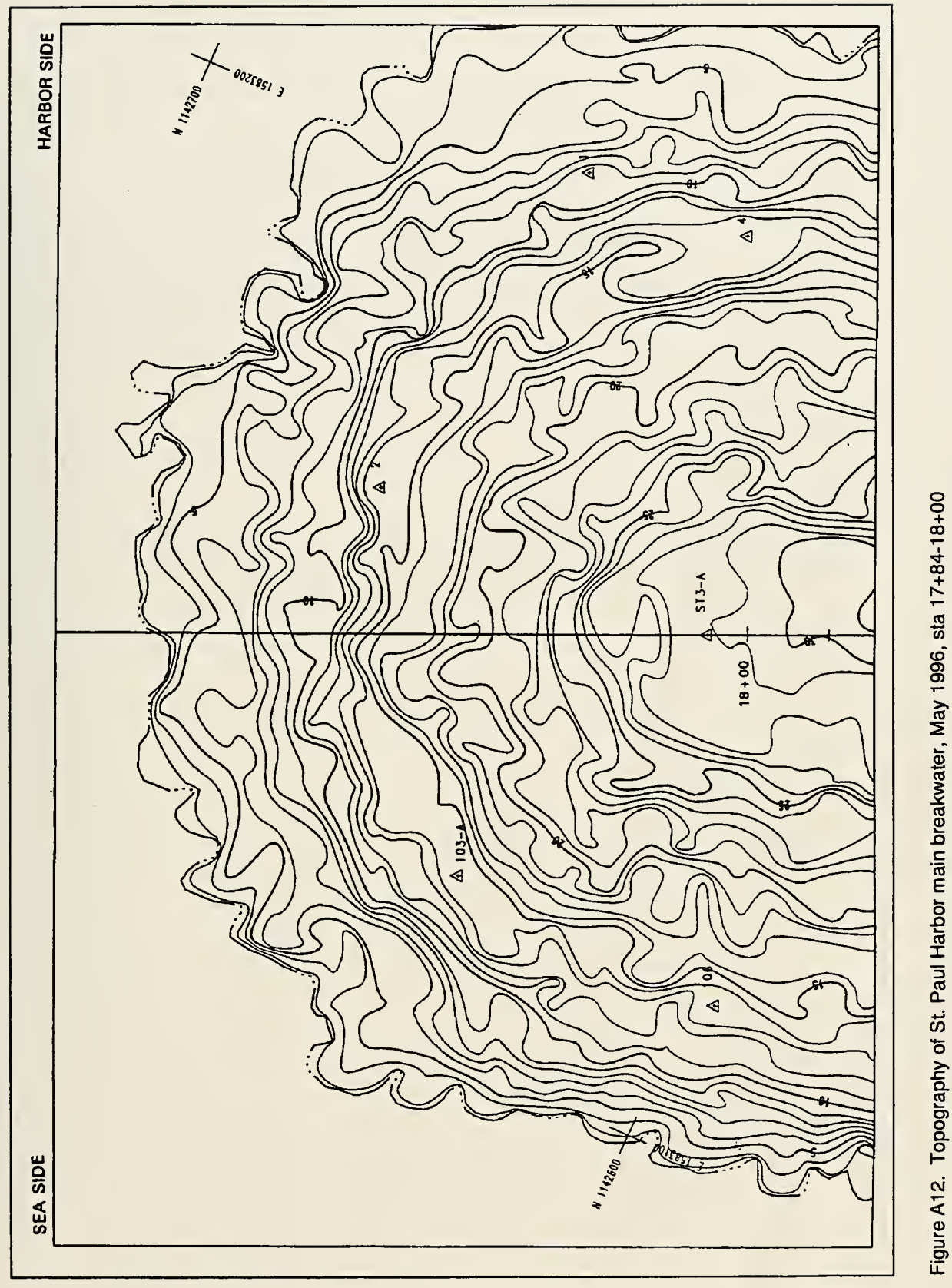





\section{Appendix B Changes in Breakwater Elevations Between 1994 and 1996}

This appendix presents differences in elevation of the St. Paul Harbor breakwater extension between the May 1994 and May 1996 photogrammetric surveys. Changes in breakwater topography are shown on a $0.3-\mathrm{m}$ (1.0-ft) contour interval. Station numbering is from a southerly to northerly direction. The scale of the maps is $2.54 \mathrm{~cm}=6.1 \mathrm{~m}(1$ in. $=20 \mathrm{ft})$. 


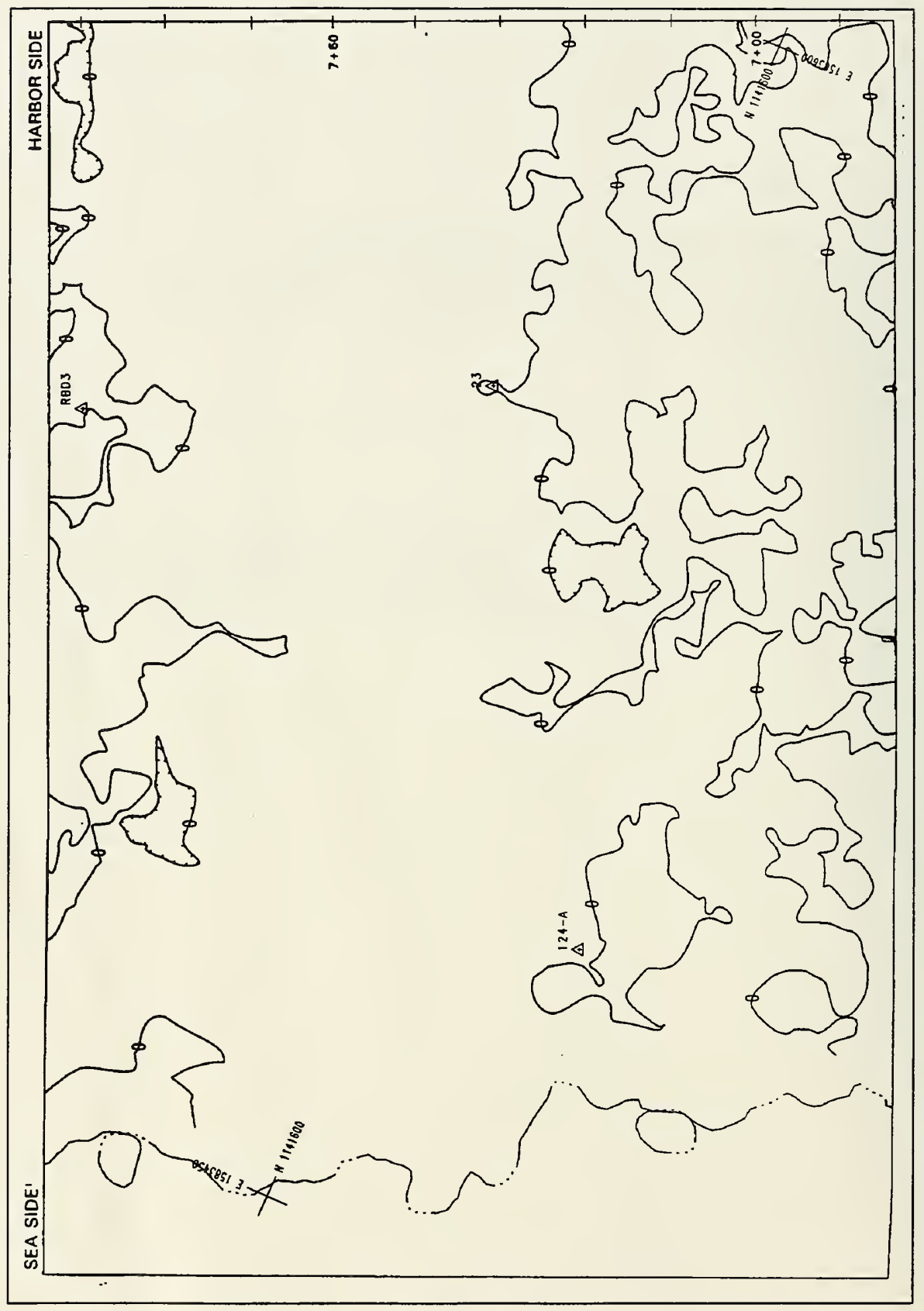

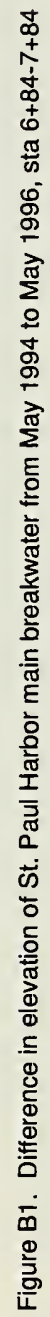




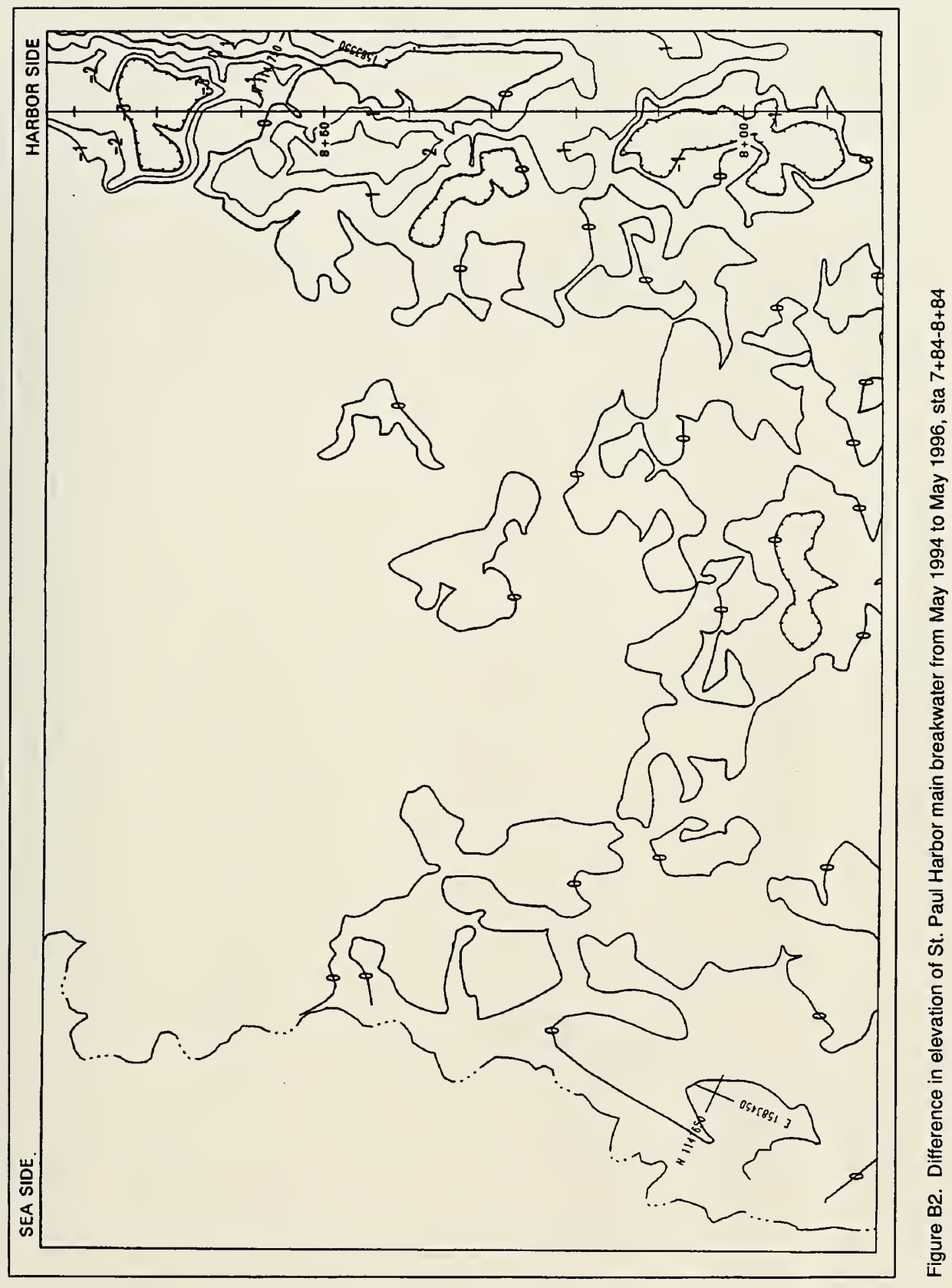




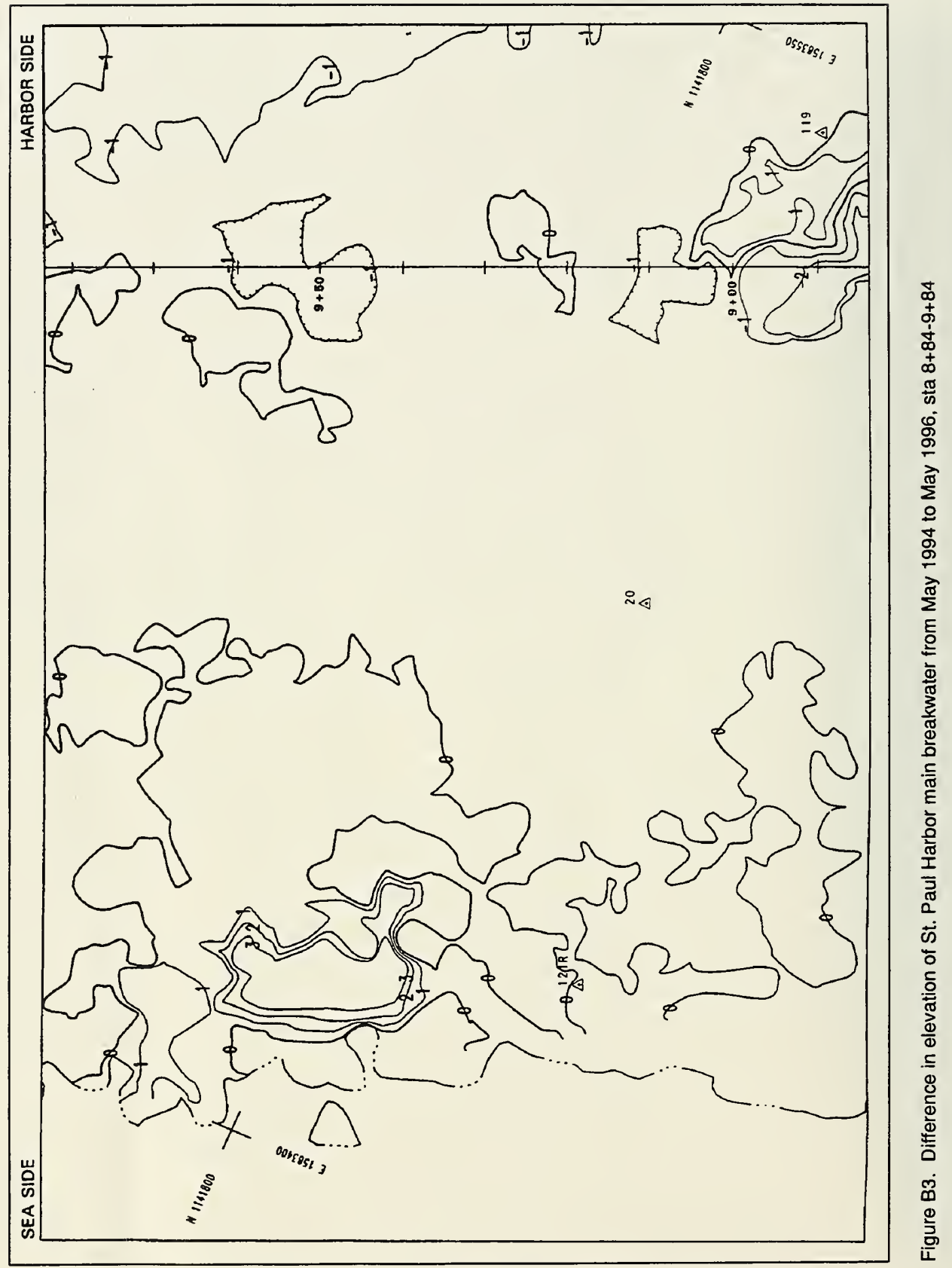




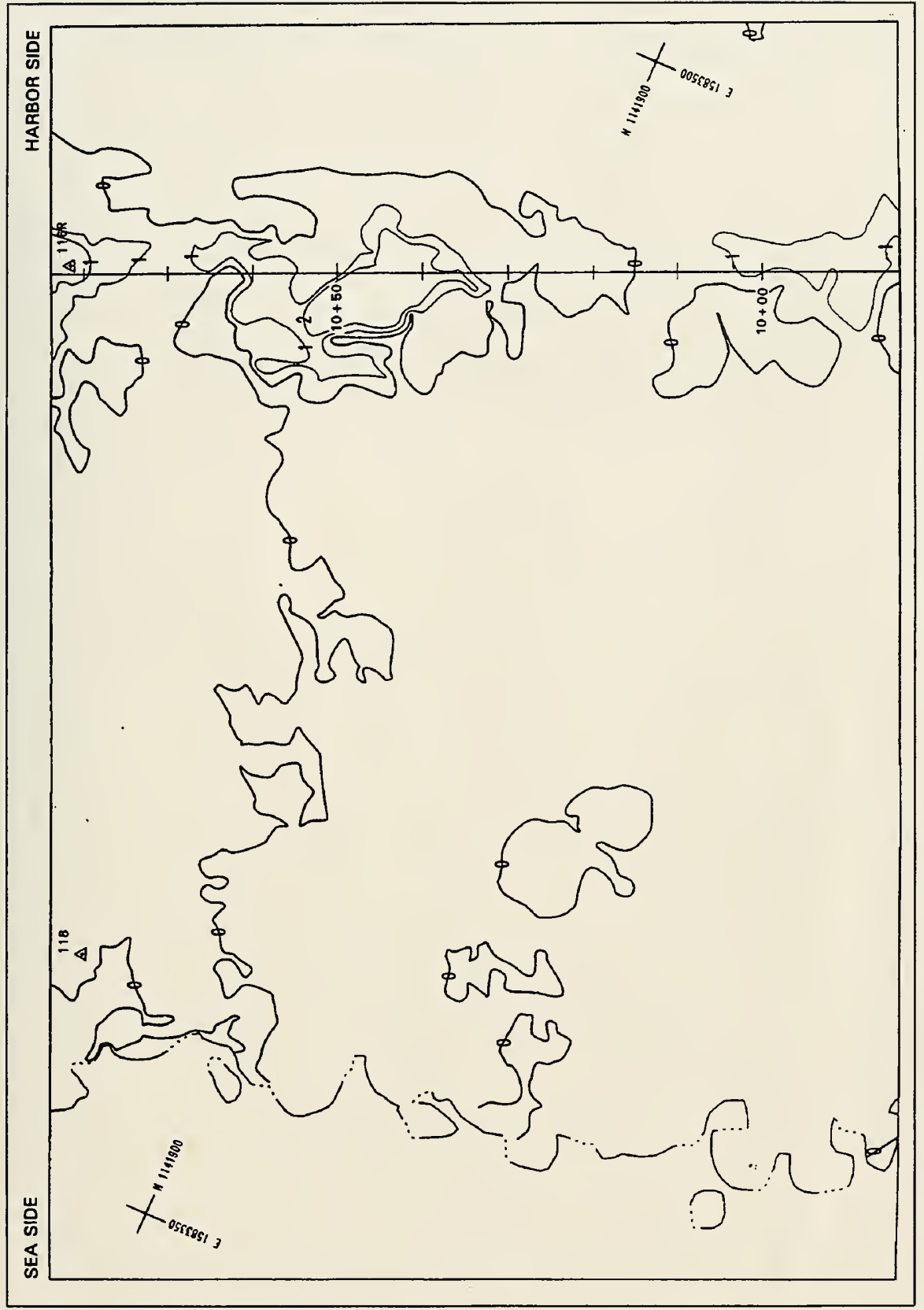

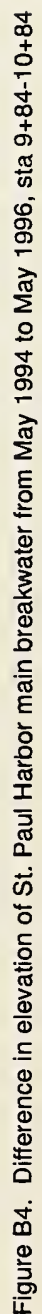




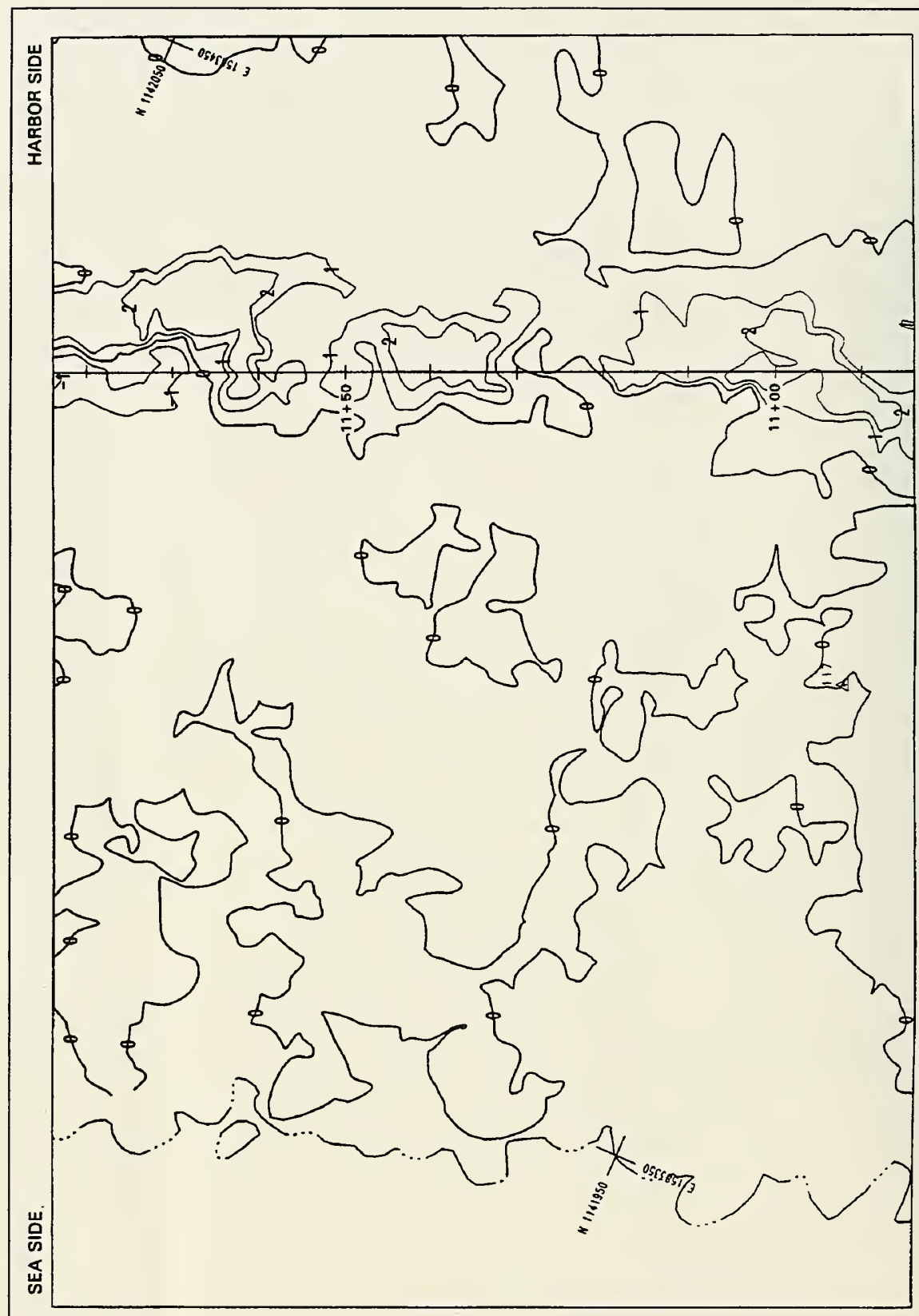




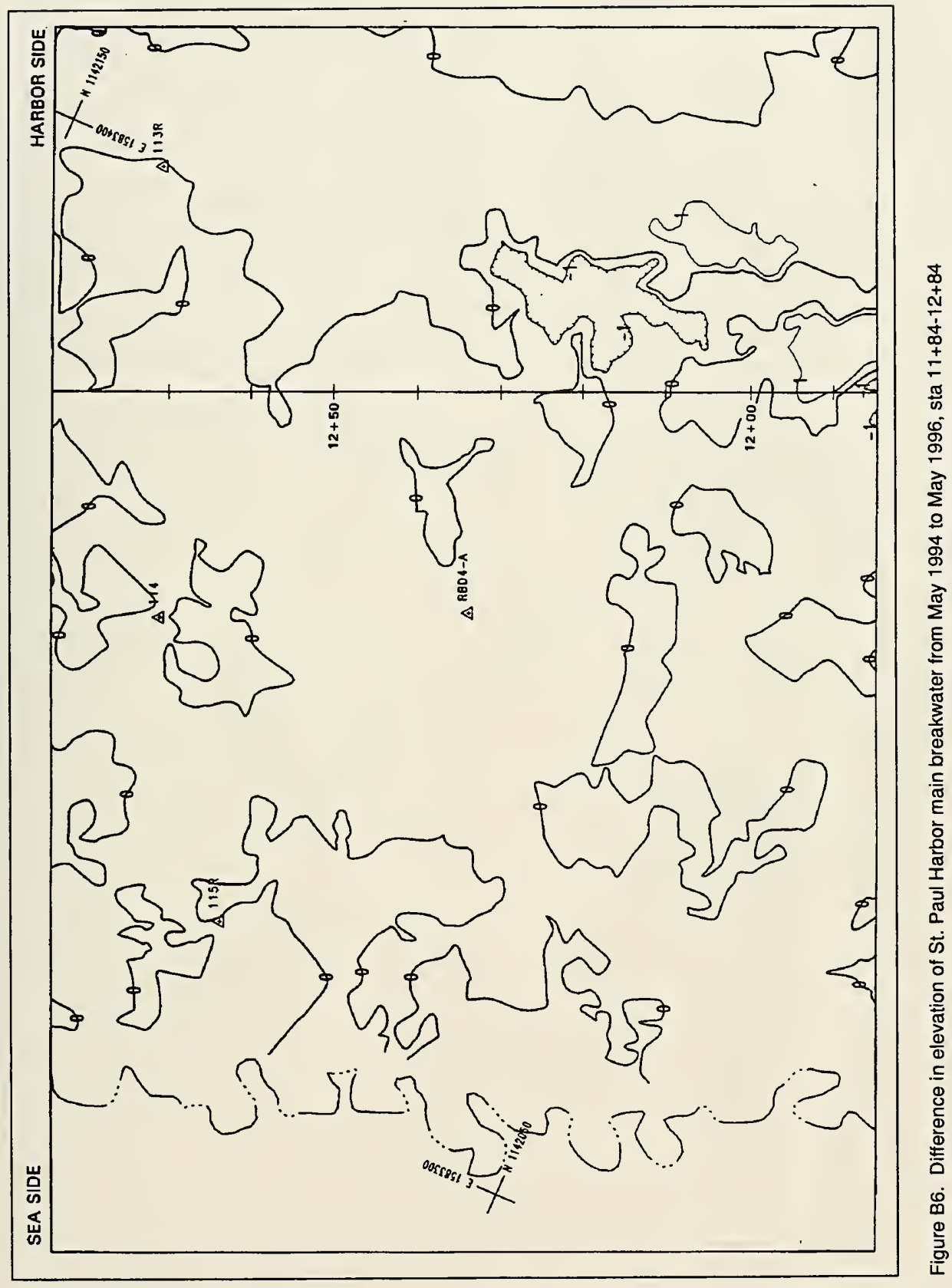




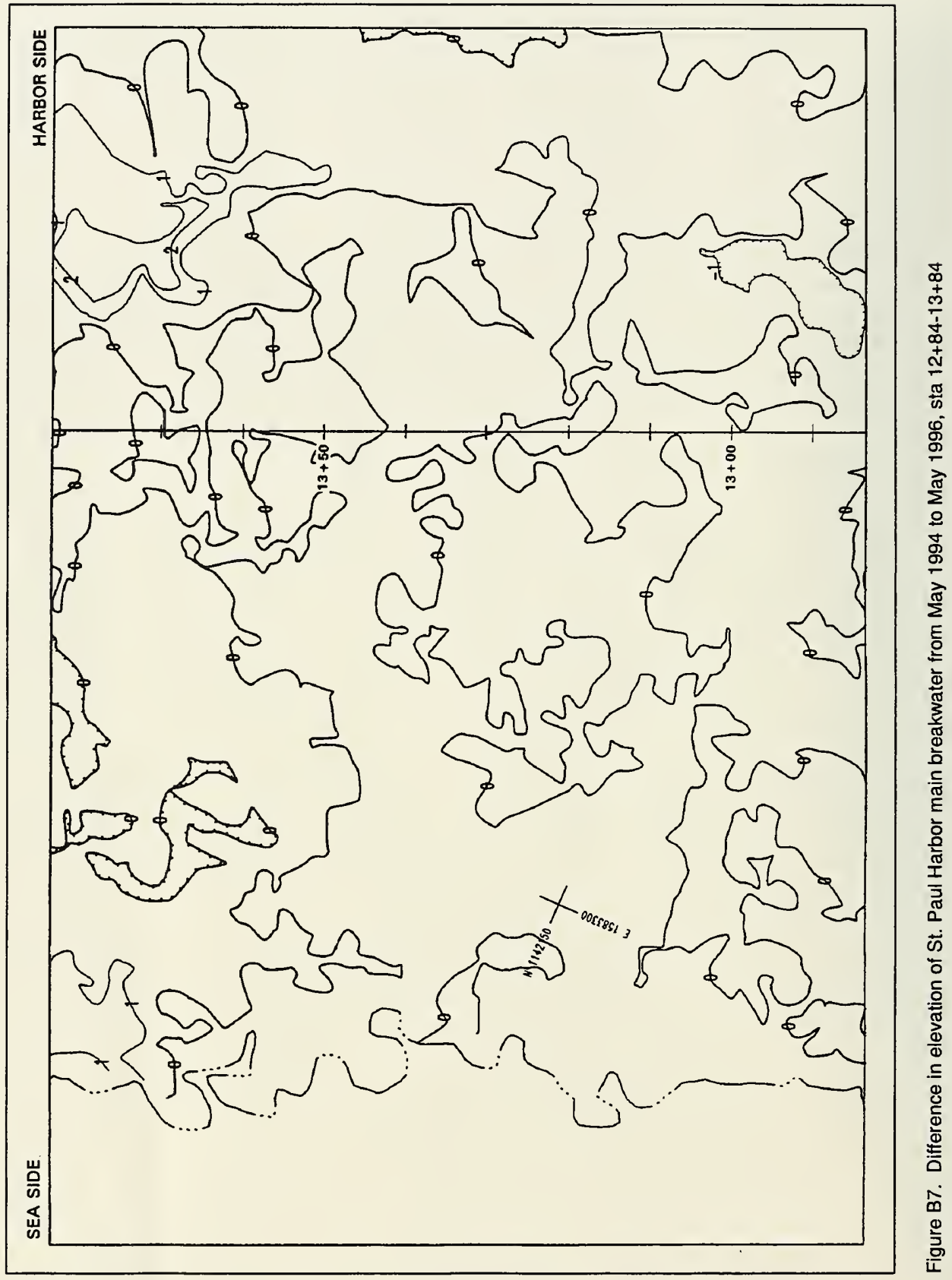




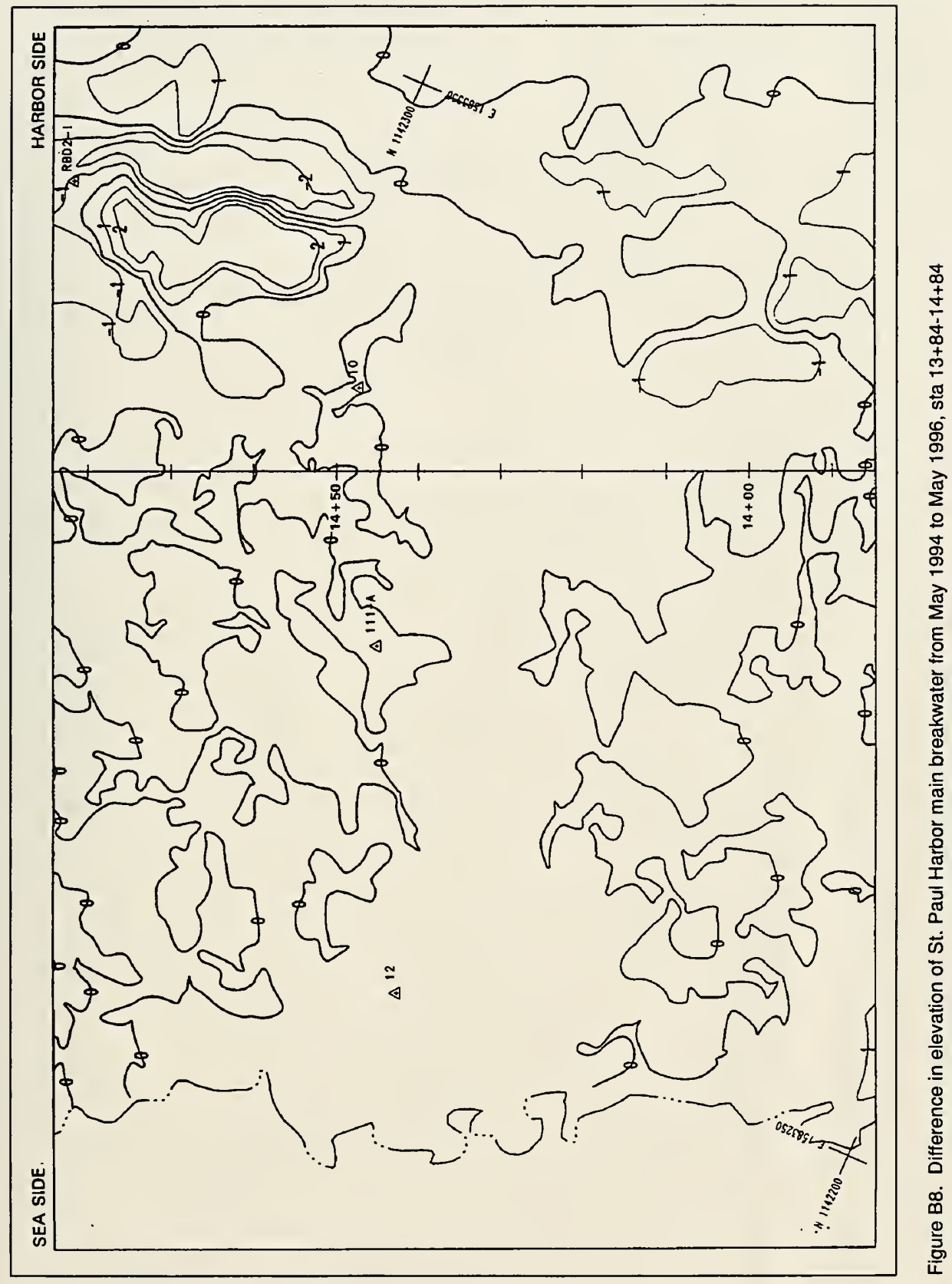




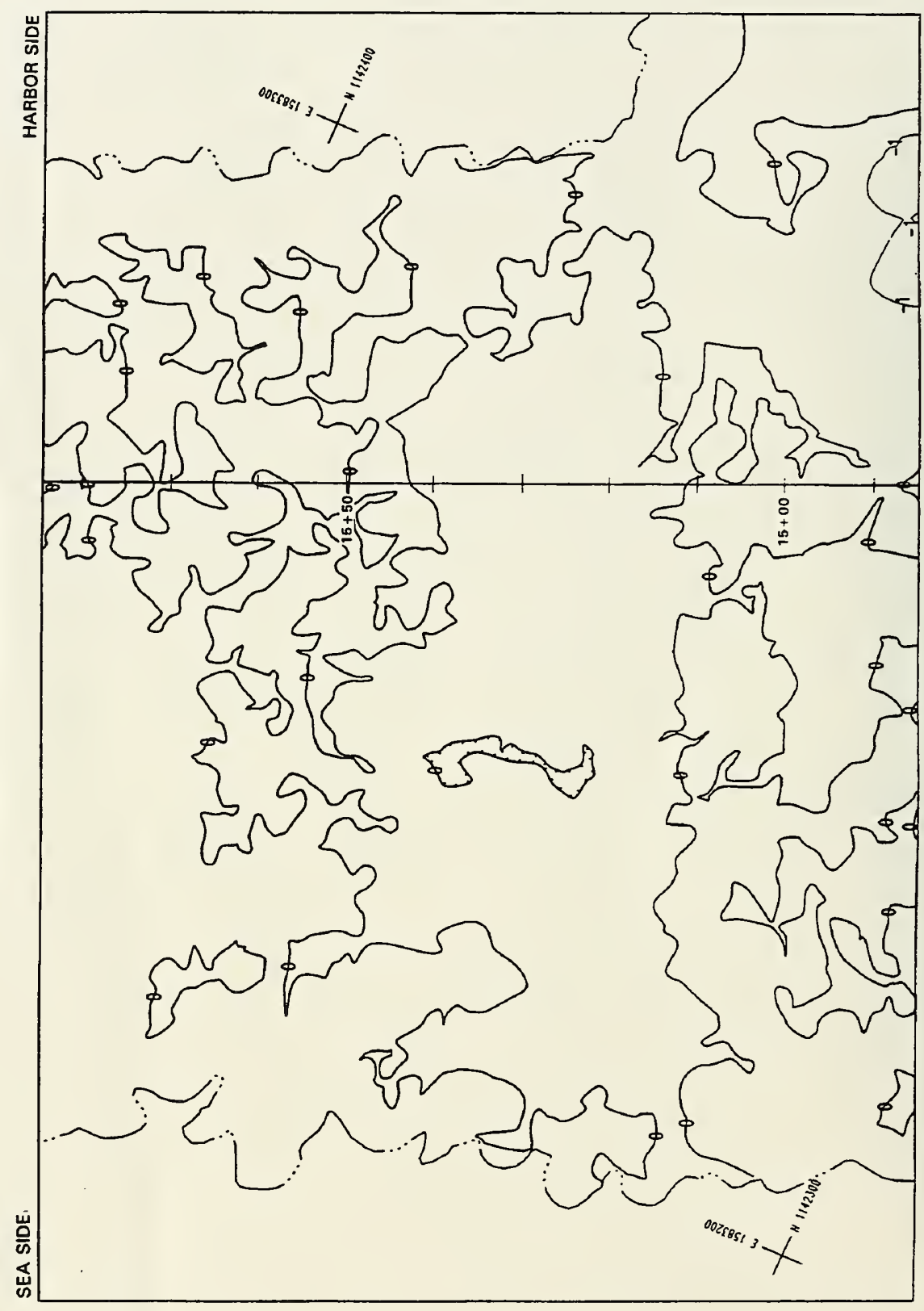

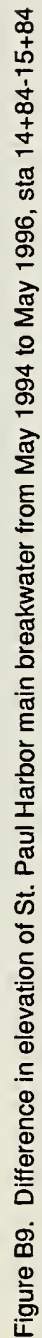




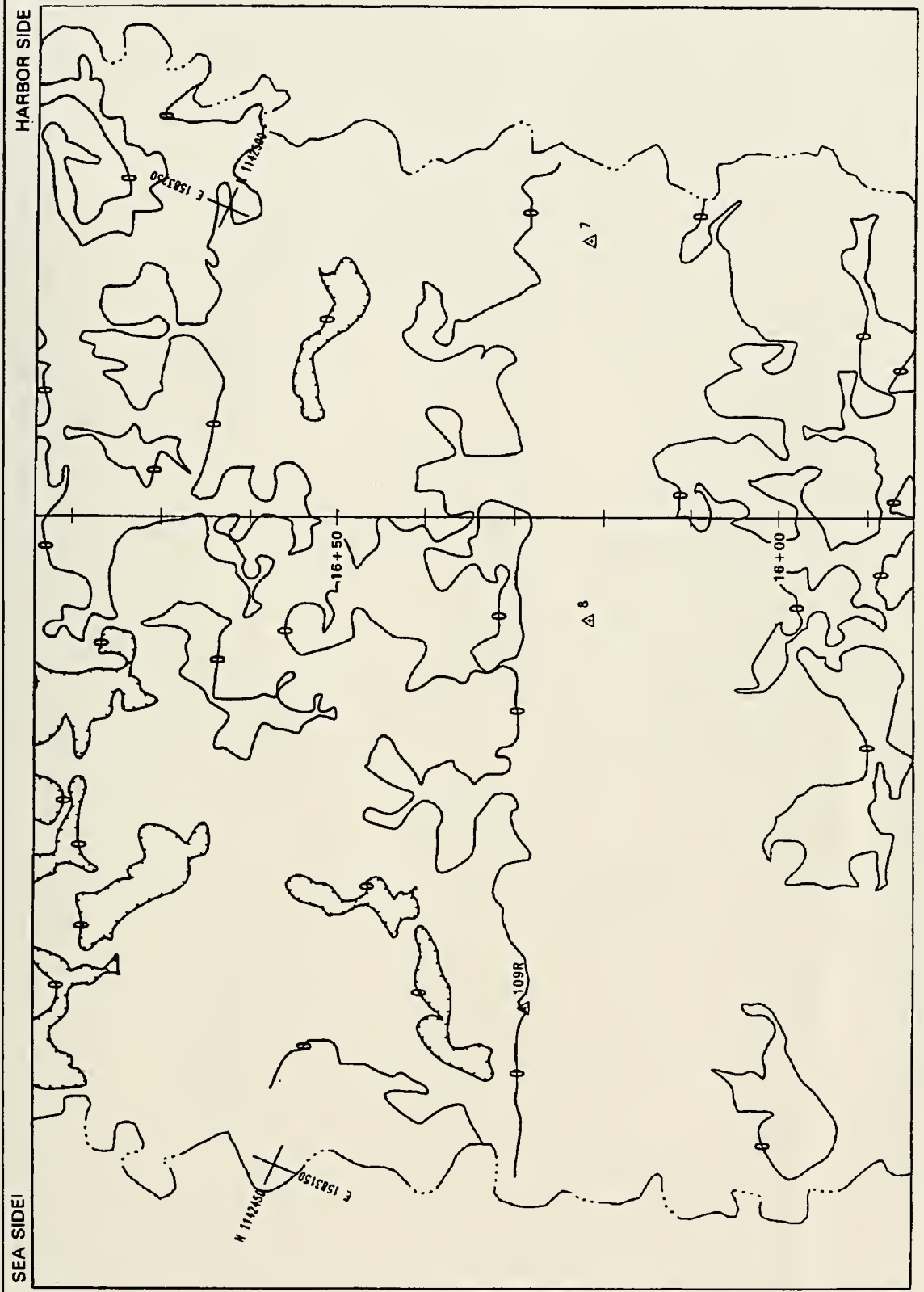

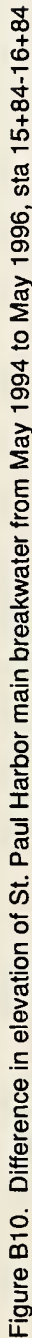




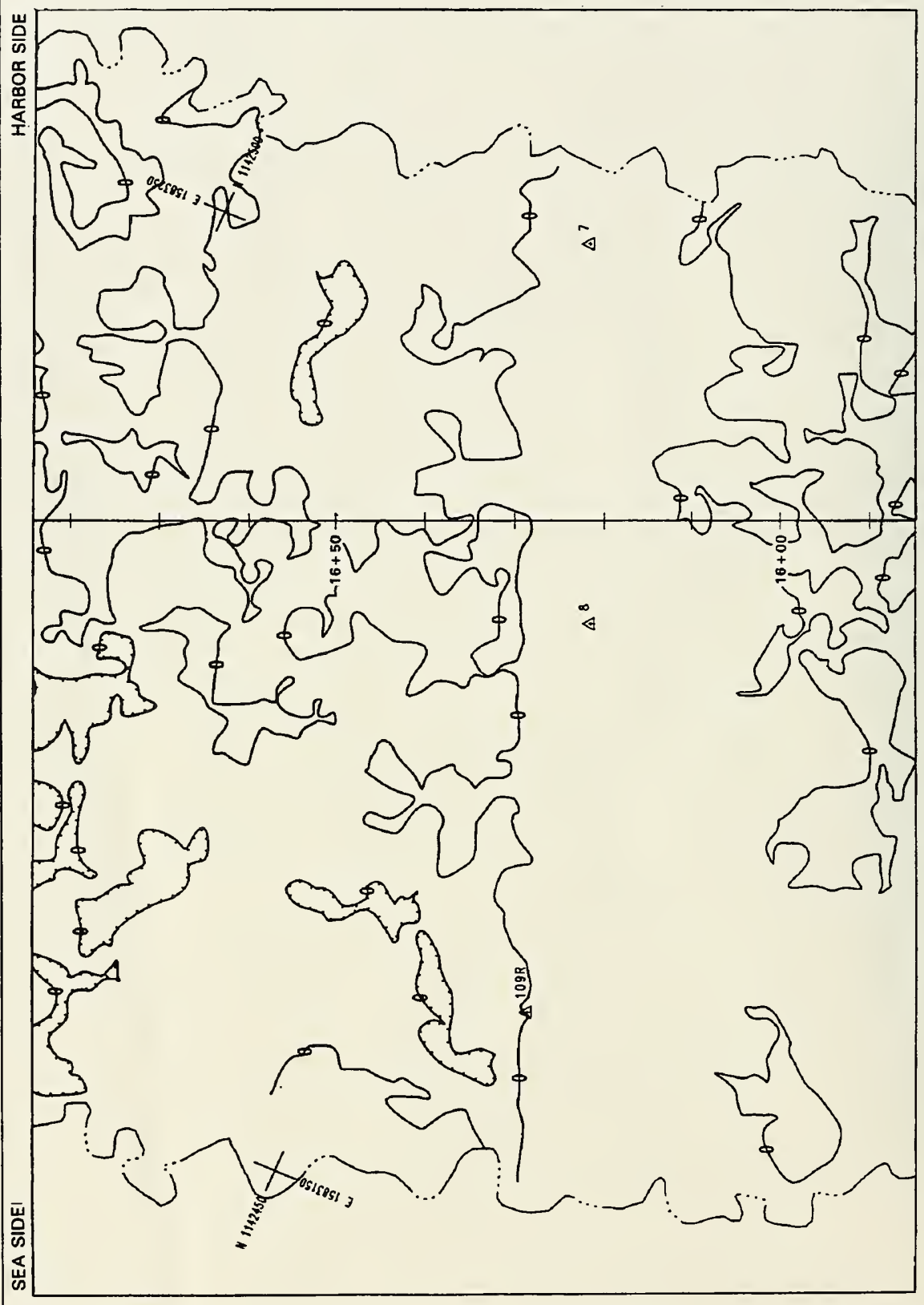

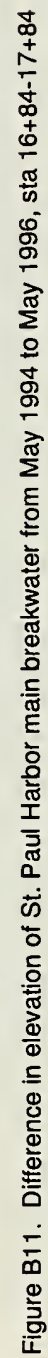




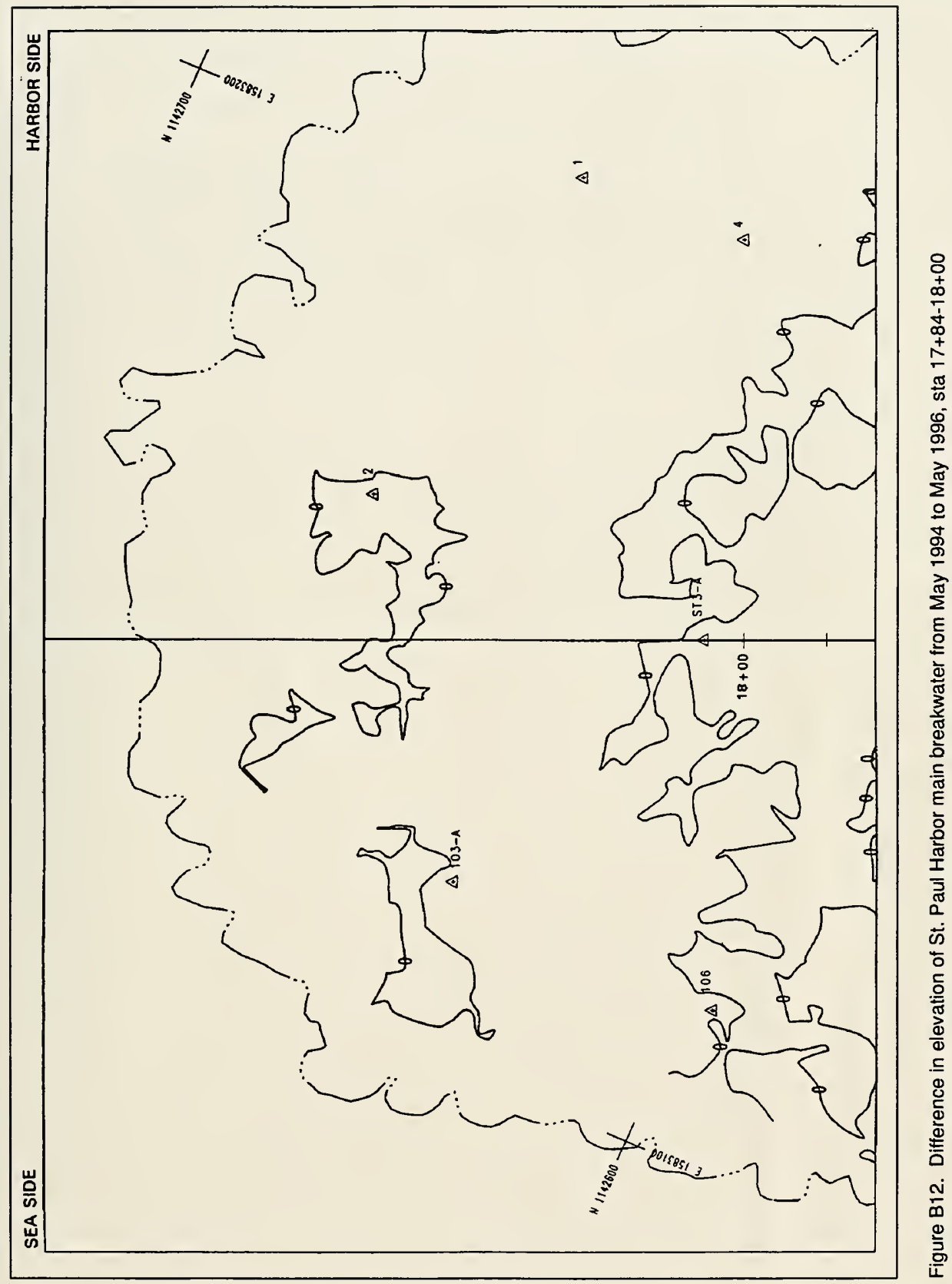


. 


\section{Appendix C Breakwater Cross Sections, 1994 and 1996}

This appendix presents cross sections of the St. Paul Harbor breakwater extension for the 1994 and 1996 surveys. Cross sections were developed using the digital terrain model (DTM) grid as stated in the main text of this report. They were obtained at $30.5-\mathrm{m}(100-\mathrm{ft})$ intervals along the trunk of the breakwater. Elevations shown are in feet referred to mean lower low water (mllw) datum. Distances from the baseline also are shown in feet. Negative distances are measured relative to the sea side of the baseline and positive distances are measured relative to the harbor side of the baseline. 


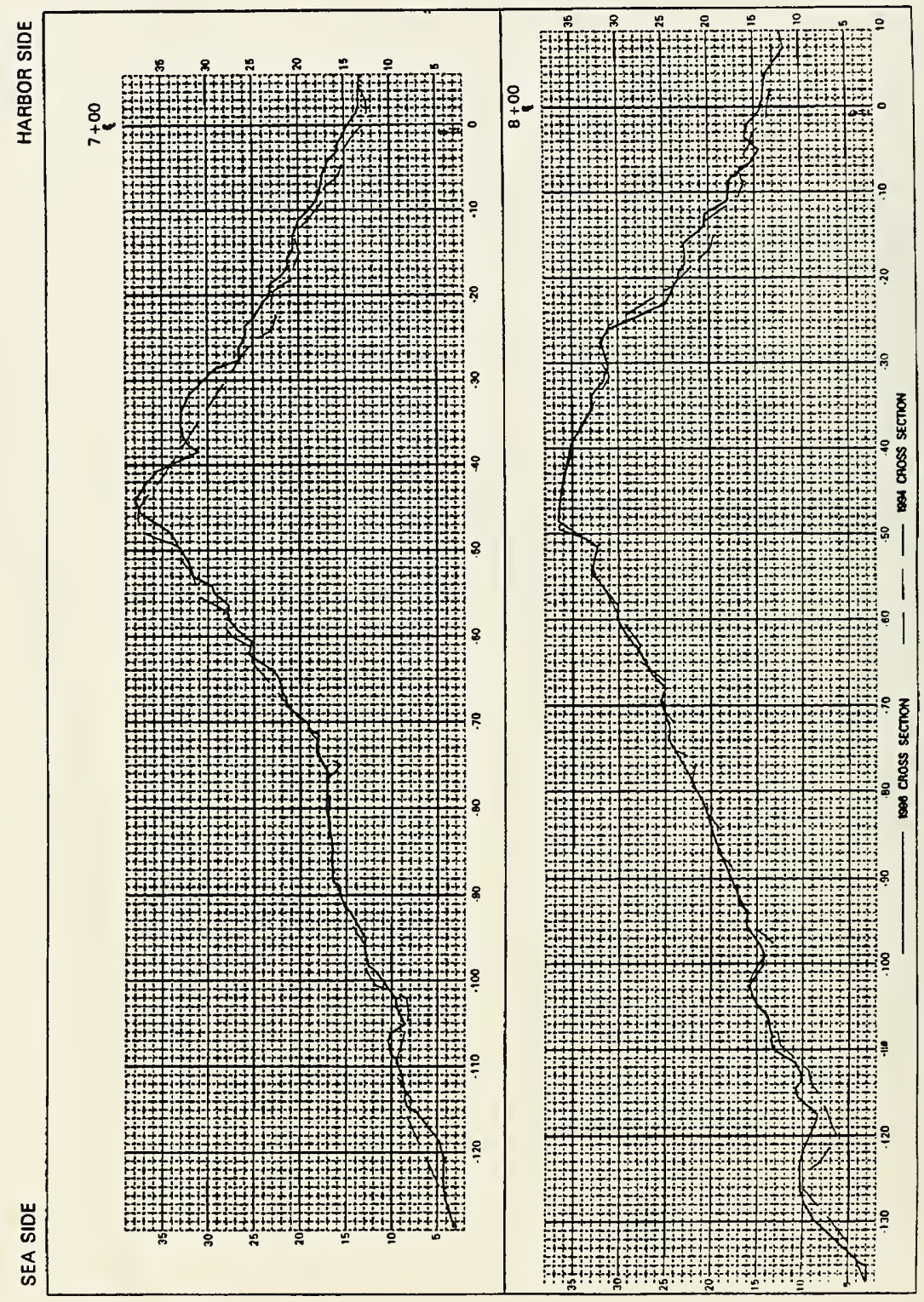




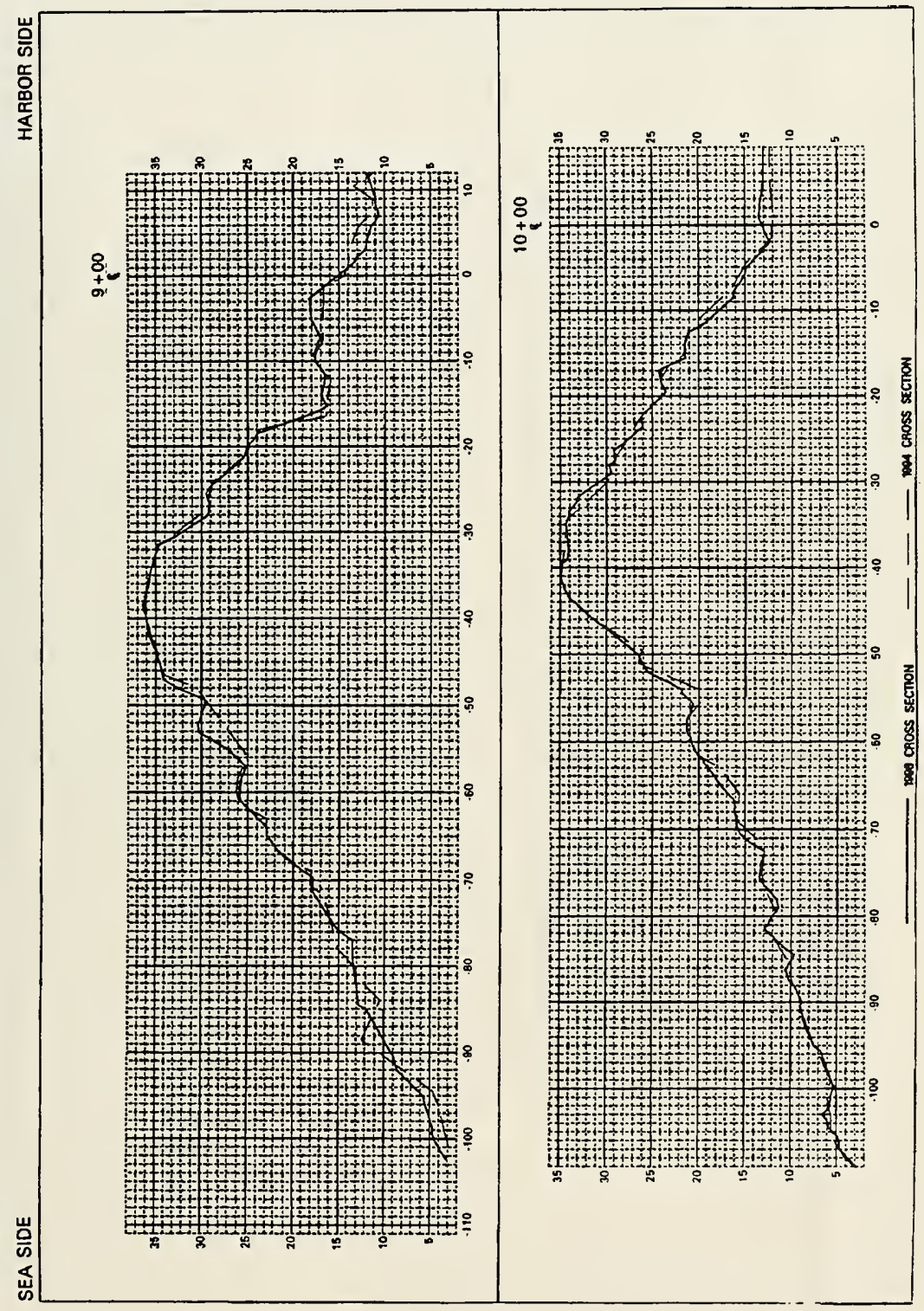

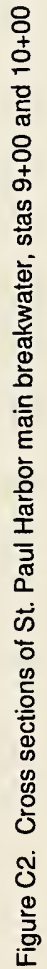




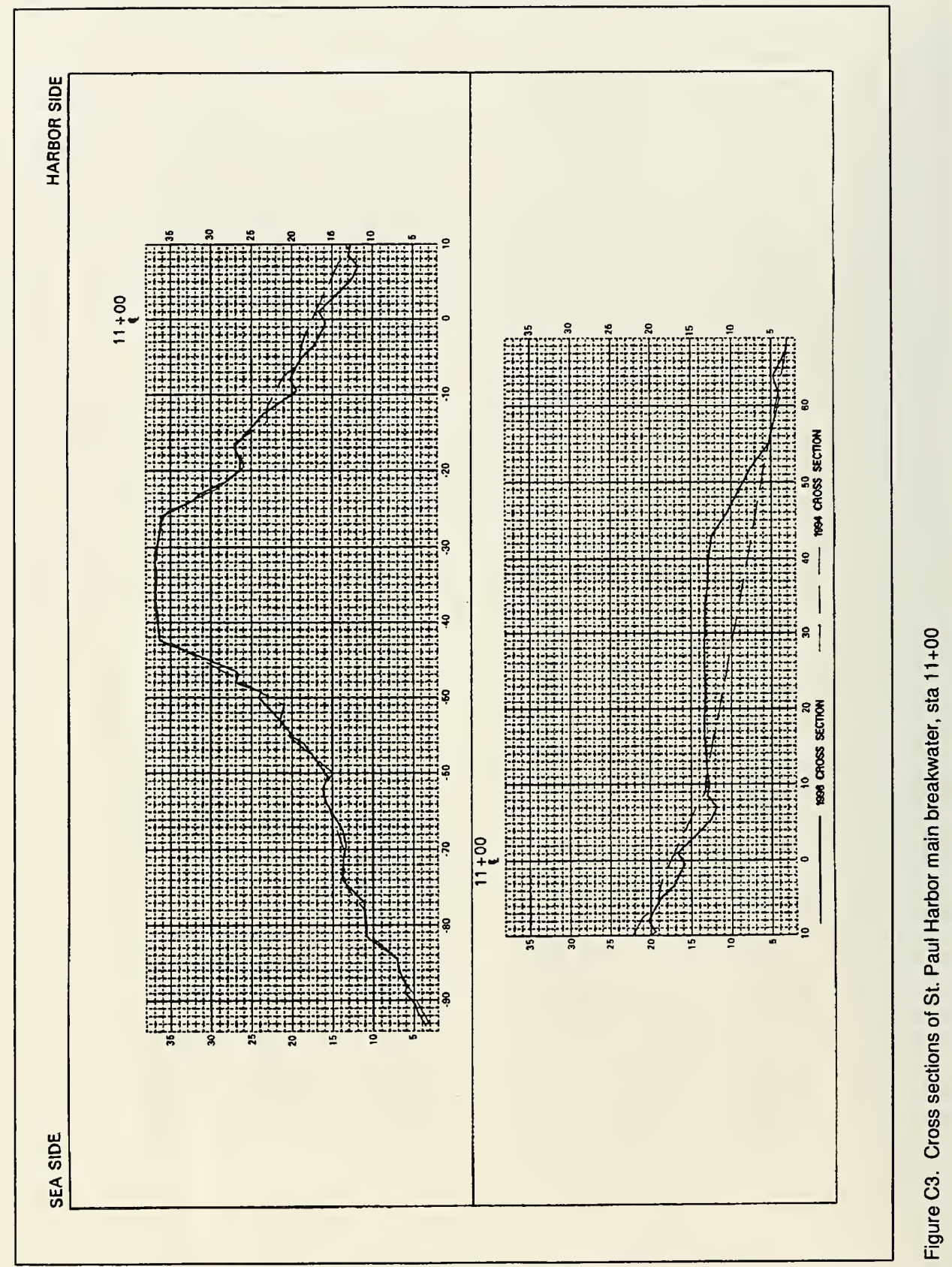




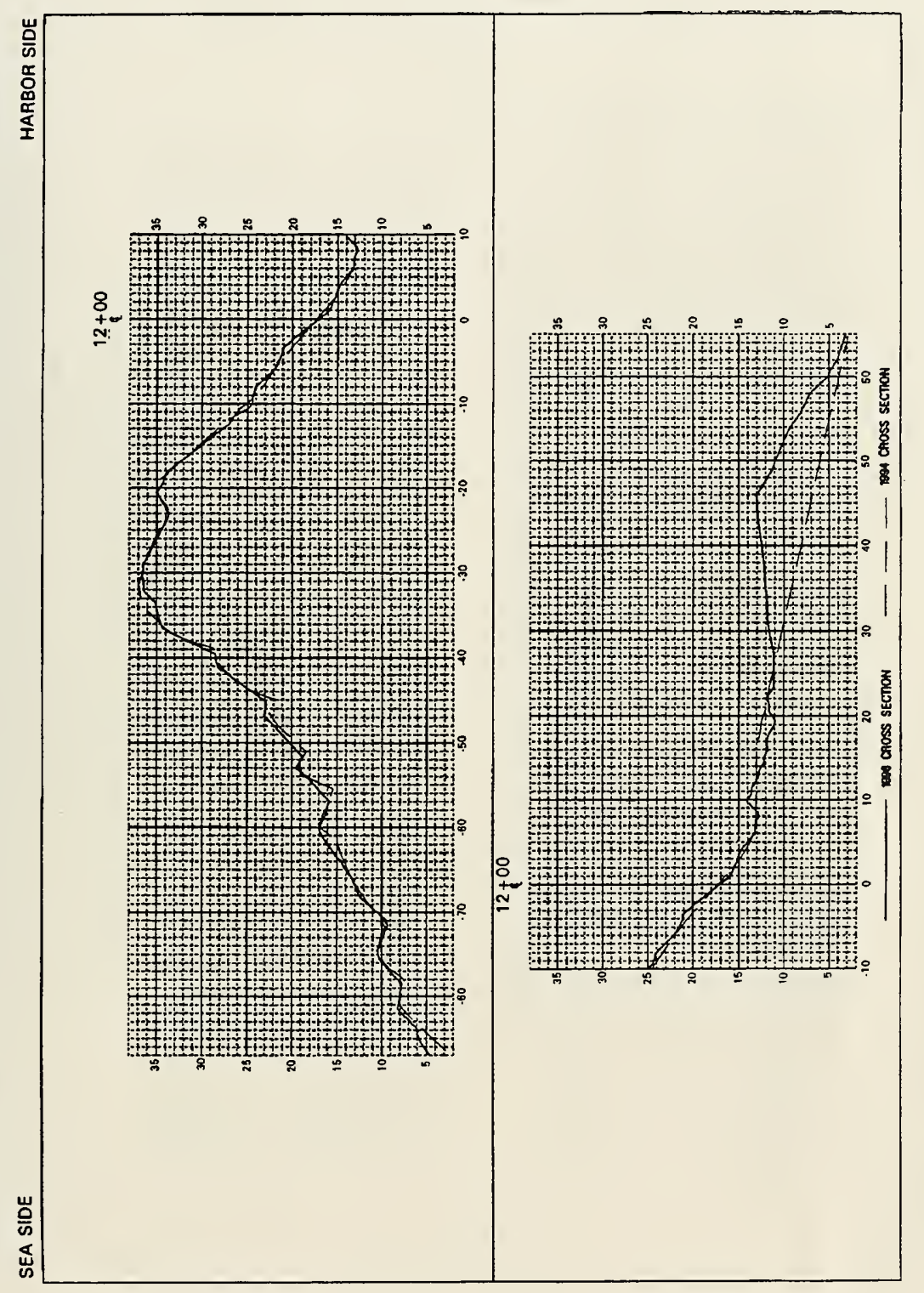

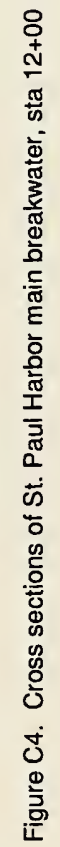




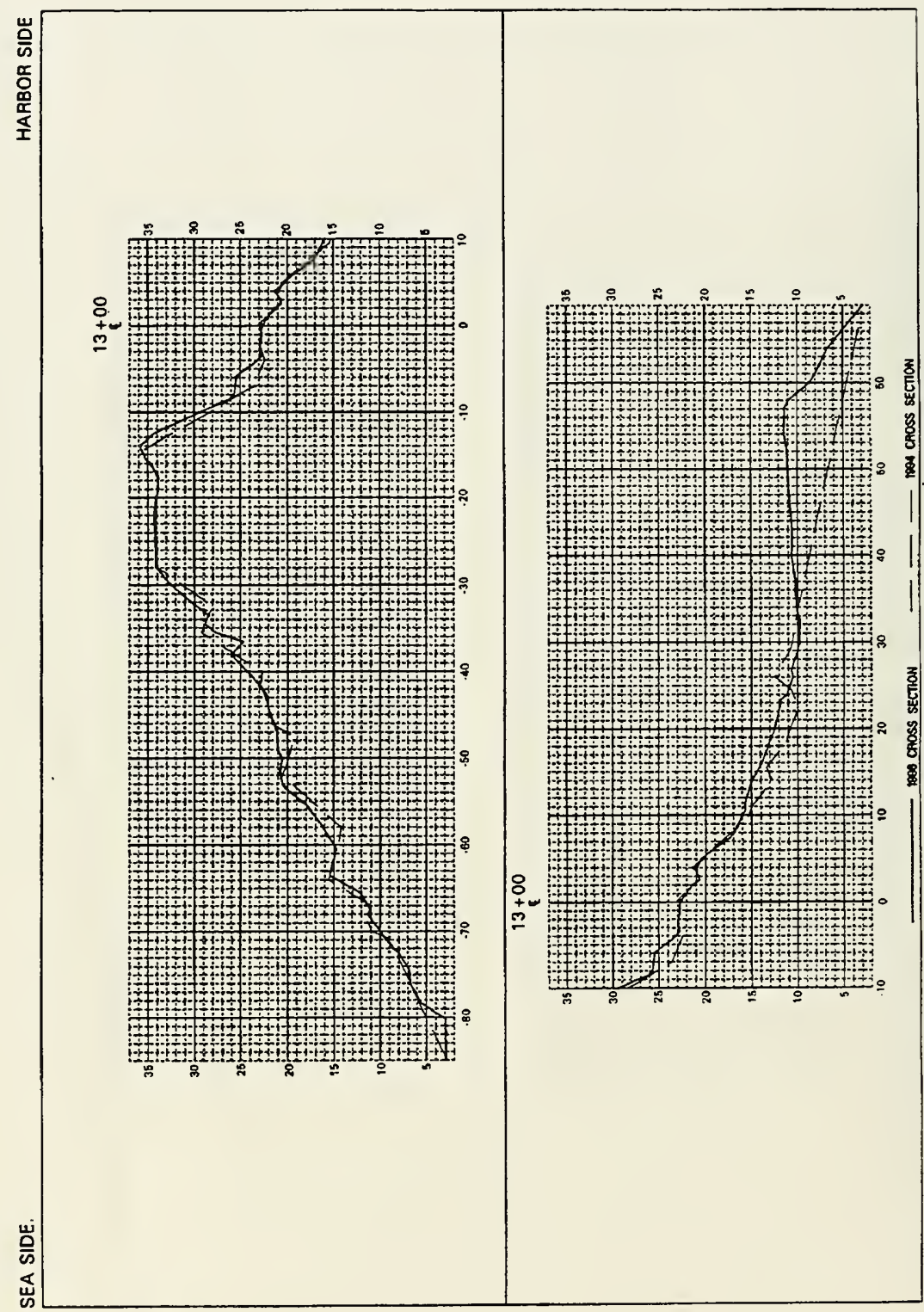

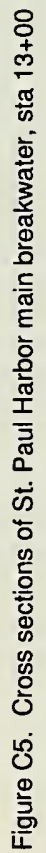




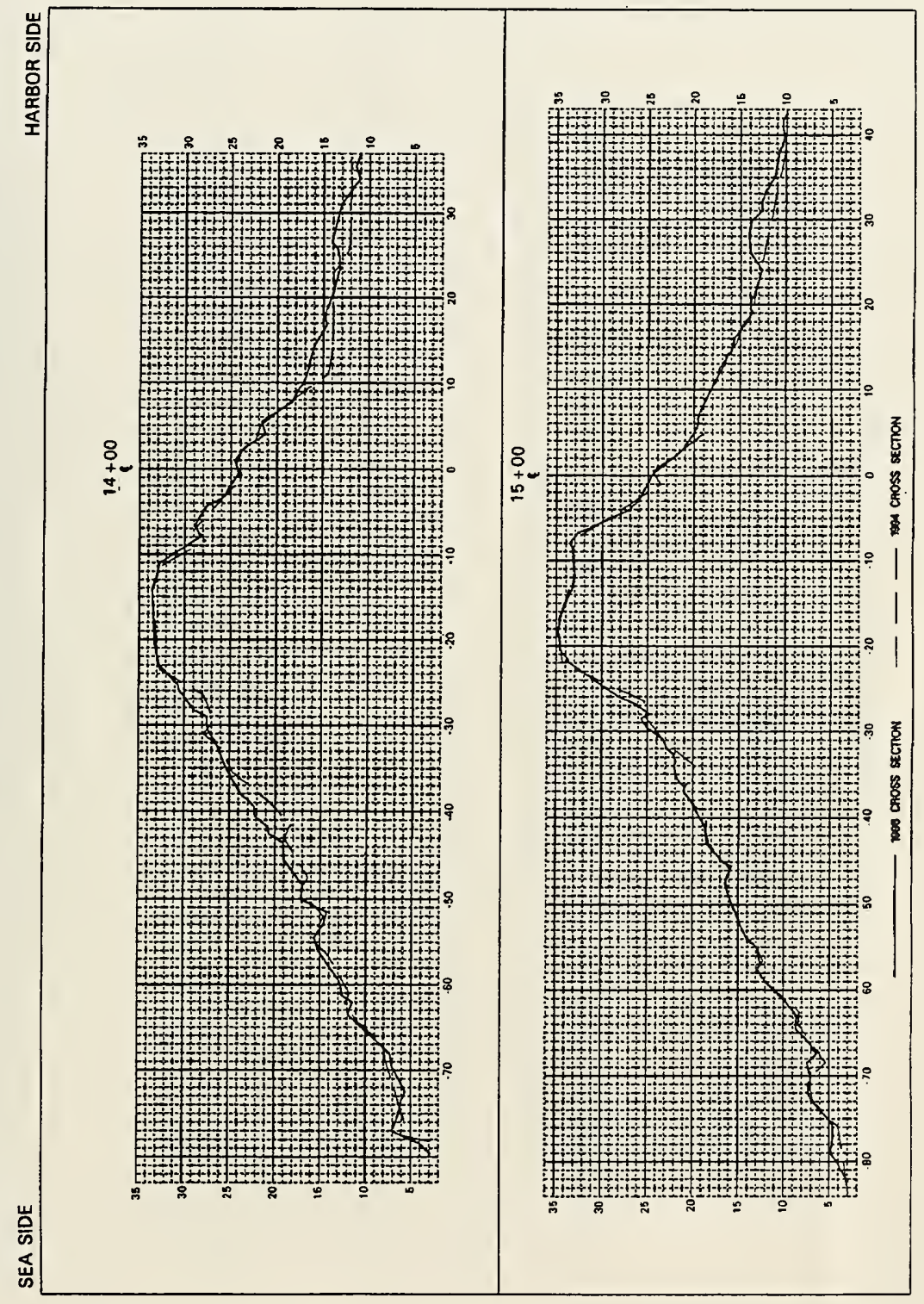

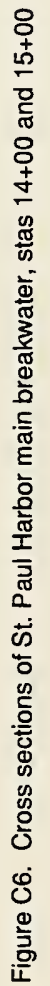




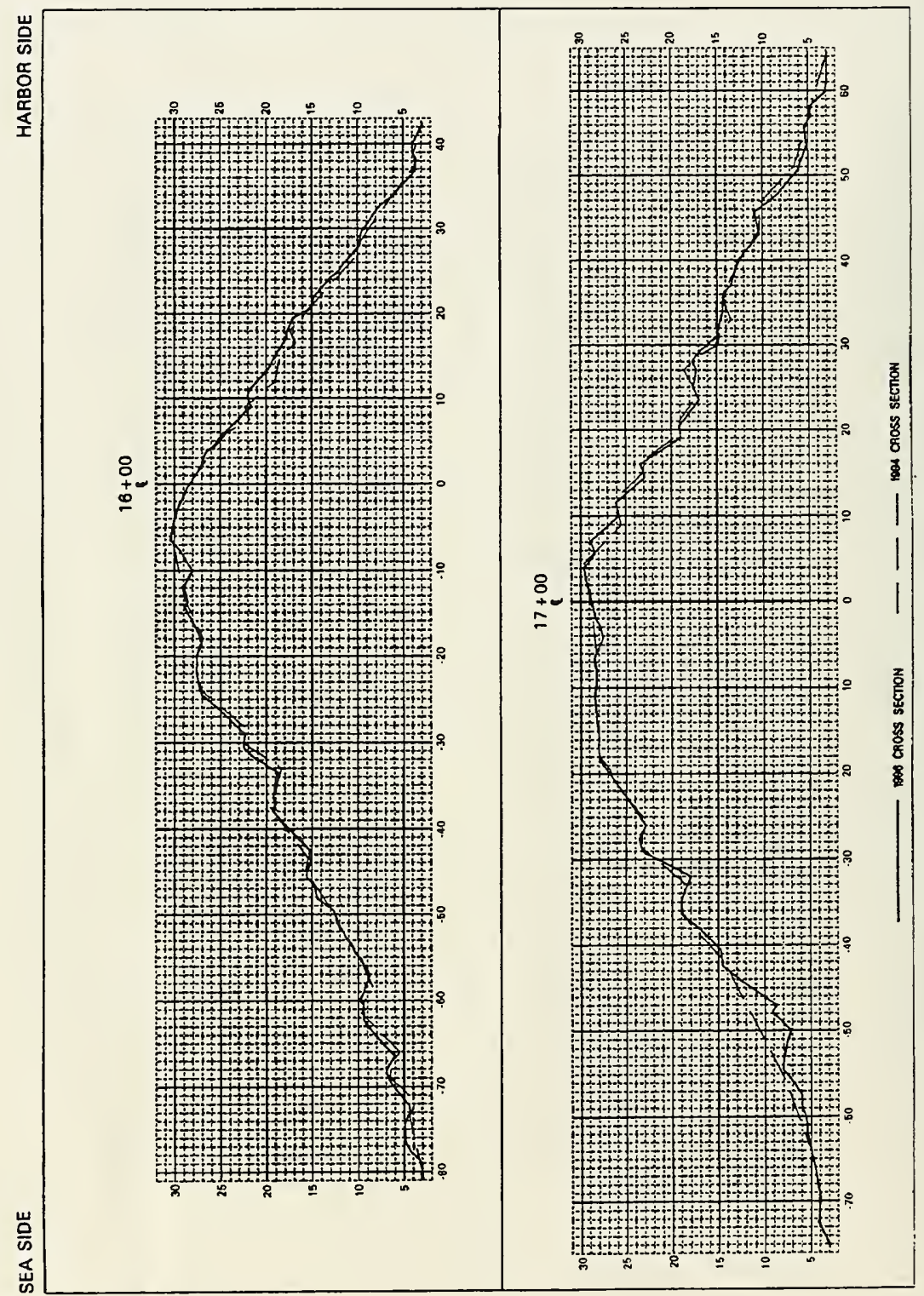

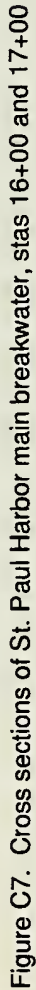




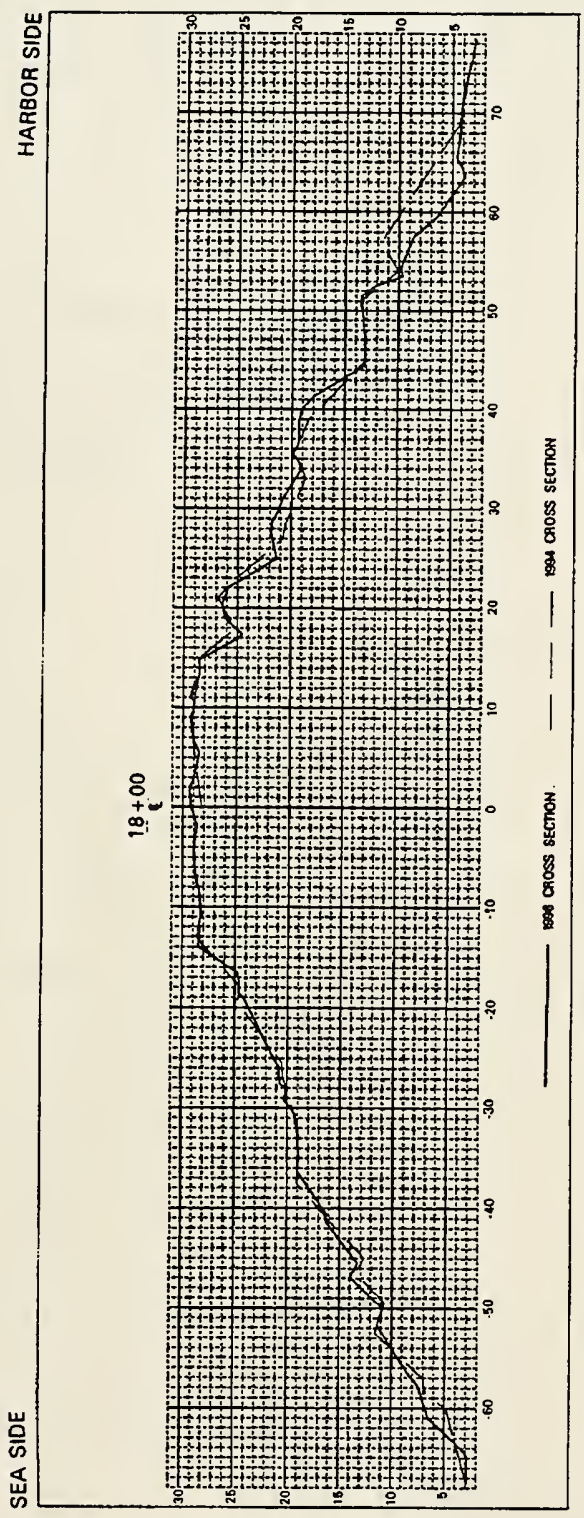

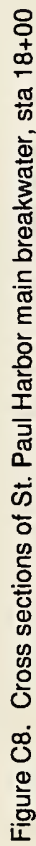





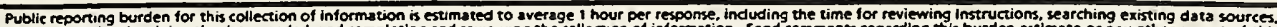
gatherng and maintaining the data needed, and completing and reviewing the collection of information. Send comments regarding this burden extimate or any other aspect of this collection of information, including suggestions for reducing this burden, to Washington Headquarters Services, Director ate for Information Operations and Reports, 1215
Devis Highway, Suite 1204, Arlington, VA 22202-4302, and to the Office of Management and Budget, Paperwork Reduction Project (0704-0 is8), Washington, DC 20503.

\begin{tabular}{|l|l|l}
\hline 1. AGENCY USE ONLY (Leave blank) & 2. REPORT DATE & 3. REPORT TYPE AND DATES COVERED
\end{tabular}

July 1997

Final report

4. TITLE AND SUBTITLE

5. FUNDING NUMBERS

Monitoring of Harbor Improvements at St. Paul Harbor, St. Paul

Island, Alaska

6. AUTHOR(S)

Robert R. Bottin, Jr., Kenneth J. Eisses

\section{PERFORMING ORGANIZATION NAME(S) AND ADDRESS(ES)}

8. PERFORMING ORGAMIZATION REPORT NUMBER

U.S. Army Engineer Waterways Experiment Station 3909 Halls Ferry Road, Vicksburg, MS 39180-6199

U.S. Army Engineer District, Alaska

P.O. Box 898, Anchorage, AK 99506-0898

9. SPONSORING/MONITORING AGENCY NAME(S) AND ADORESS(ES)

CHL-97-13

U.S. Army Corps of Engineers

Washington, DC 20314-1000

\section{SUPPLEMENTARY NOTES}

Available from National Technical Information Service, 5285 Port Royal Road, Springfield, VA 22161.

12a. DISTRIBUTION/AVAILABILITY STATEMENT

12b. DISTRIBUTION CODE

Approved for public release; distribution is unlimited

13. ABSTRACT (Maximum 200 words)

In 1992, St. Paul Harbor, Alaska, was approved for inclusion in the Monitoring Completed Navigation

Projects Program. The objective of the monitoring plan for St. Paul Harbor was to determine if the harbor and its structures were performing (both functionally and structurally) as predicted by model studies used in the project design. Monitoring of the harbor was conducted during the period July 1993 through June 1996. Elements of the monitoring program included prototype wave gauging, wave hindcast study, wave runup, wave overtopping, bathymetric analysis, broken armor unit surveys, and photogrammetric analysis.

Wave height data obtained inside the harbor appeared to validate a previous three-dimensional model study. A videotape analysis used to obtain wave runup data along the face of the St. Paul Harbor main breakwater was successful, except during periods of low visibility. Trends in wave hindcast data obtained outside the harbor correlated reasonably well with runup data in a qualitative sense. Absolute values of the hindcast significant wave heights, however, appeared to be substantially lower than the waves experienced in the prototype based on runup values measured, overtopping observed, and local forecasts.

Although the St. Paul Harbor main breakwater is currently functioning in an acceptable manner and is in good condition structurally, armor stone continues to degrade. Continued deterioration is predicted due to freeze-thaw and wet-dry cycles as well as large waves and sea ice action. Photogrammetric analysis revealed most of the breakwater extension was below its design elevation.

\section{SUBJECT TERMS}

Broken armor unit survey

Monitoring Completed Navigation Projects Program OF REPORT
Photogrammetry

St. Paul Harbor, Alaska

Wave runup and overtopping
19. SECURITY CLASSIFICATION OF ABSTRACT
SPONSORING/MONITORING AGENCY REPORT NUMBER 

Destroy this report when no longer needed. Do not return it to the originator. 

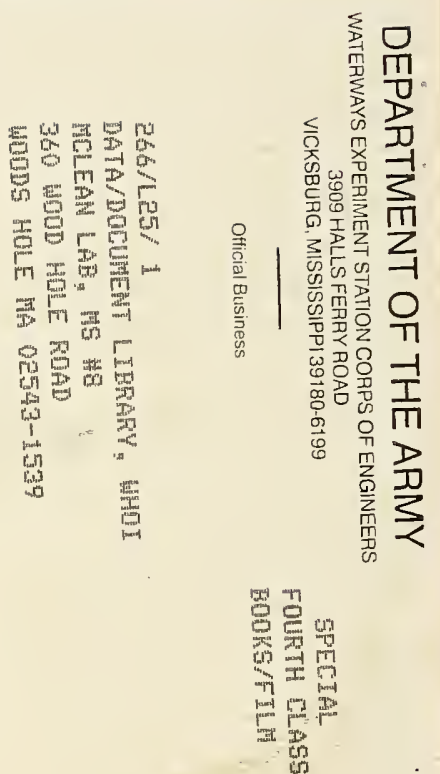